San Jose State University

SJSU ScholarWorks

Master's Theses

Master's Theses and Graduate Research

Summer 2012

\title{
The Biology and Ecology of six rare plants from Plumas National Forest, Northern California, USA
}

Suzie Woolhouse

San Jose State University

Follow this and additional works at: https://scholarworks.sjsu.edu/etd_theses

\section{Recommended Citation}

Woolhouse, Suzie, "The Biology and Ecology of six rare plants from Plumas National Forest, Northern California, USA" (2012). Master's Theses. 4221.

DOI: https://doi.org/10.31979/etd.9xbj-dtb2

https://scholarworks.sjsu.edu/etd_theses/4221

This Thesis is brought to you for free and open access by the Master's Theses and Graduate Research at SJSU ScholarWorks. It has been accepted for inclusion in Master's Theses by an authorized administrator of SJSU ScholarWorks. For more information, please contact scholarworks@sjsu.edu. 
THE BIOLOGY AND ECOLOGY OF SIX RARE PLANTS FROM PLUMAS NATIONAL FOREST, NORTHERN CALIFORNIA, USA

\author{
A Thesis \\ Presented to \\ The Faculty of the Department of Biological Sciences
}

San José State University

In Partial Fulfillment

of the Requirements for the Degree

Master of Science

by

Suzie Woolhouse

August 2012 
(C) 2012

Suzie Woolhouse

ALL RIGHTS RESERVED 
The Designated Thesis Committee Approves the Thesis Titled

THE BIOLOGY AND ECOLOGY OF SIX RARE PLANTS FROM PLUMAS NATIONAL FOREST, NORTHERN CALIFORNIA, USA

by

Suzie Woolhouse

APPROVED FOR THE DEPARTMENT OF BIOLOGICAL SCIENCES

SAN JOSÉ STATE UNIVERSITY

August 2012

Dr. Nishanta Rajakaruna

Department of Biological Sciences

Dr. Susan Lambrecht

Department of Biological Sciences

Dr. Will Russell

Department of Environmental Studies 


\section{ABSTRACT \\ THE BIOLOGY AND ECOLOGY OF SIX RARE PLANTS FROM PLUMAS NATIONAL FOREST, NORTHERN CALIFORNIA, USA}

by Suzie Woolhouse

The majority of our knowledge about the natural world has come from the study and observation of common species, yet a significant portion of species in the world are rare. In this study, biological and ecological data was collected for six rare taxa from Plumas National Forest. The taxa were Monardella stebbinsii, Monardella follettii (Lamiaceae), Lewisia cantelovii (Montiaceae), Cypripedium californicum, Cypripedium fasciculatum (Orchidaceae) and Clarkia mildrediae subsp. mildrediae (Onagraceae). The two Monardella's and Cypripedium californicum are serpentine endemics, and the Lewisia is found growing both on and off serpentine. Five sites were visited per species, and soil samples and leaf tissue were collected to examine elemental concentrations in the soil and respective ion uptake. Detailed studies were conducted on the three rarest taxa, including comparative ecology and reproductive biology of the two congeners and a reciprocal transplant to assess the extent of local adaptation to substrate in $L$.

cantelovii. Significant differences were found in the study of the two Monardella's and Lewisia cantelovii showed early evidence for local adaptation to substrate. Gaining a better understanding of the biology and ecology of these rare plants will increase the efficacy of management practices as well as provide data in order to inform a multispecies conservation approach. 


\section{ACKNOWLEDGEMENTS}

I would like to thank my thesis advisor, Dr. Nishanta (Nishi) Rajakaruna, who instilled in me a great enthusiasm for serpentine ecosystems throughout the world as well as provided endless support and guidance in the field and at school. My thesis committee members, Dr. Susan Lambrecht and Dr. Will Russell for help editing my thesis as well as guidance along the way. Dr. Rod Myatt, Dr. Jerry Smith and Dr. Jeff Honda at SJSU provided logistical support throughout my time as a Graduate Student. Dr. Earl Alexander for spending time with me in the field visiting sites to identify soil types. Dr. John Hafernik and Dr. Jeff Honda for help with insect ID. Dr. Jim Shevock for bryophyte ID. Janis Vieto was my field assistant for the Lewisia cantelovii field experiment and she also helped with pollinator observations along with Kari Olandese, Rachel Hussey, Julia Lang and Annette Bieger. I could not have done it without them. My labmate Teri Barry for help and support. Erica J. Case at UC Davis for being the best camping partner I could have wished for and for working with me my first summer of field data collection. Jim Belsher-Howe and Michelle Coppoletta of Plumas National Forest for assistance with permitting, field operations and general support in Quincy, CA. My parents (Geoff and Lynn Woolhouse) for unlimited emotional support as well as room and board. Finally I would like to thank the rare and common plants alike found in Plumas National Forest for providing me with so much joy and my grandpa Howie who instilled an appreciation of plants in me at a very young age. 
The funding for this project was provided almost entirely by the USDA Forest Service Pacific Southwest Region through a joint agreement (USDA FS \# 08-JV11272150-052) between Dr. Susan Harrison (UC Davis), Dr. Nishi Rajakaruna (SJSU) and Dr. Hugh Safford (USDA Forest Service). Additional funding was provided by the Department of Biological Sciences at San José State University, the Michael Lee Environmental Foundation and the Santa Clara Valley Chapter of the California Native Plant Society. 


\section{TABLE OF CONTENTS}

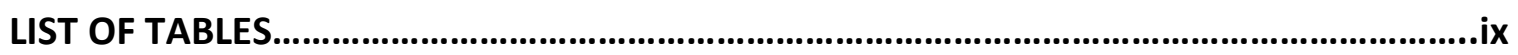

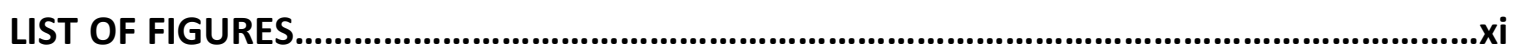

\section{CHAPTER ONE}

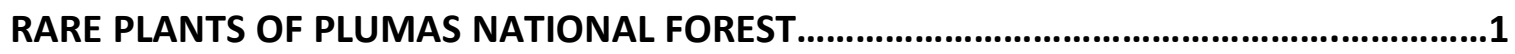

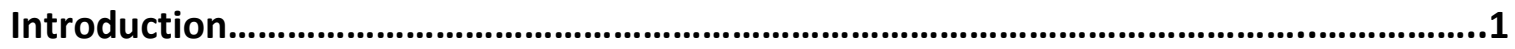

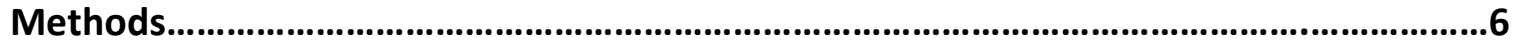

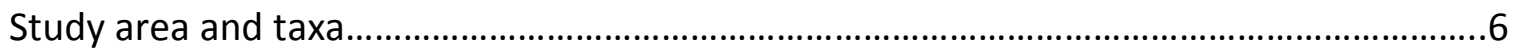

Above-ground ecology and soil-tissue ion relations........................................................

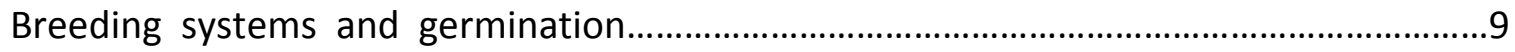

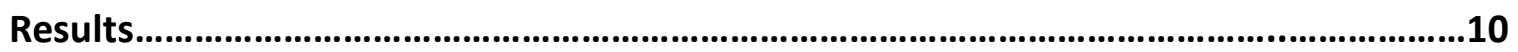

Above-ground ecology and soil-tissue ion relations......................................................10

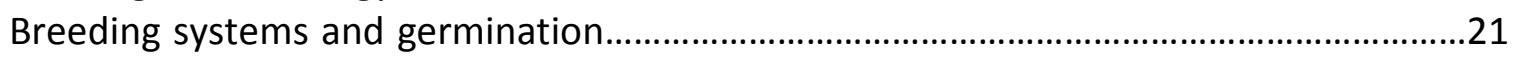

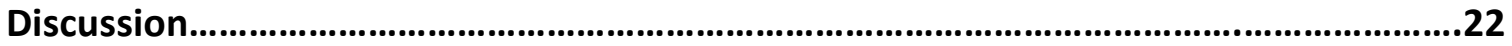

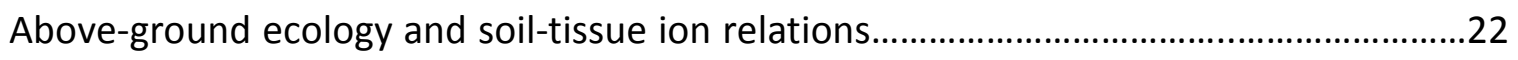

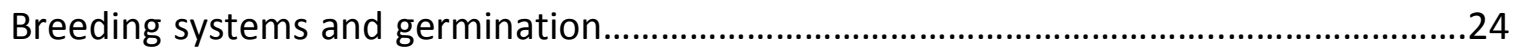

\section{CHAPTER TWO}

ECOLOGY AND REPRODUCTIVE BIOLOGY OF TWO SERPENTINE ENDEMIC

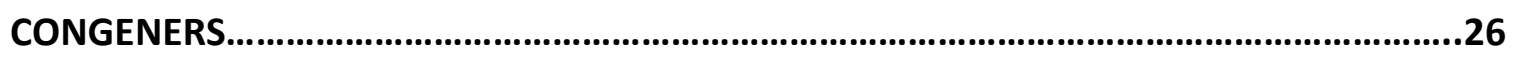

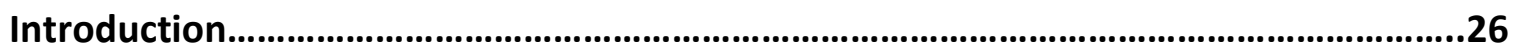

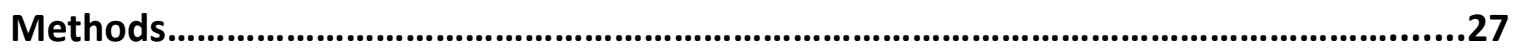

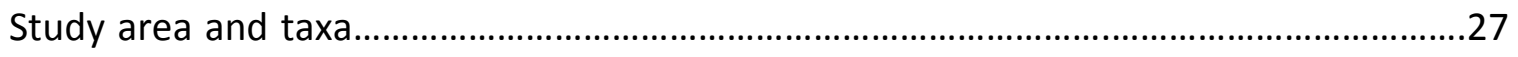

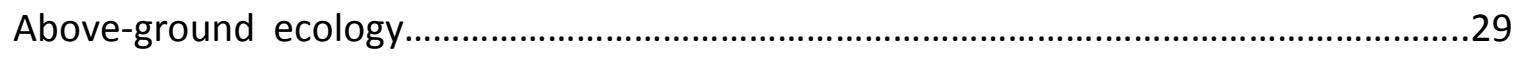

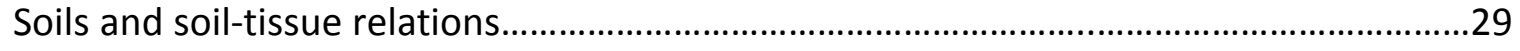

Seed germination, seedling growth and survival...........................................................29

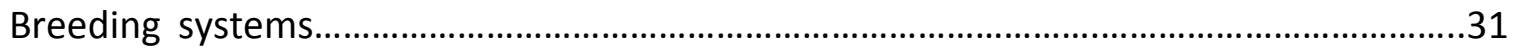

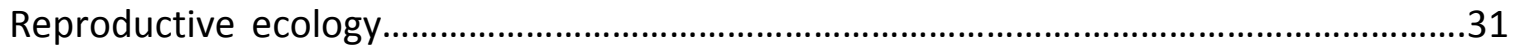




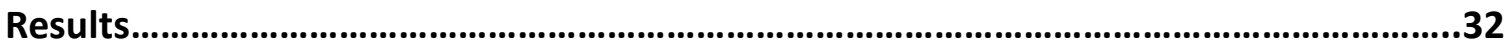

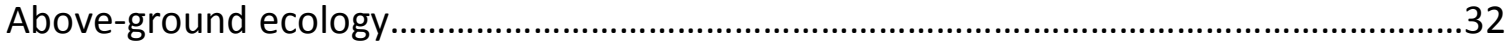

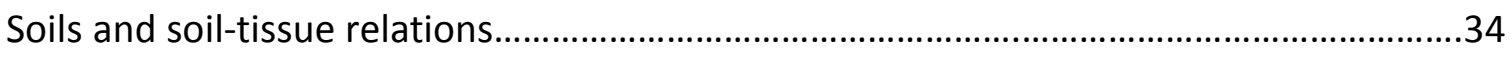

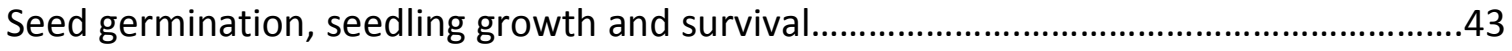

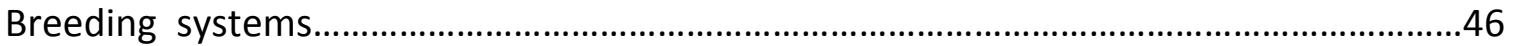

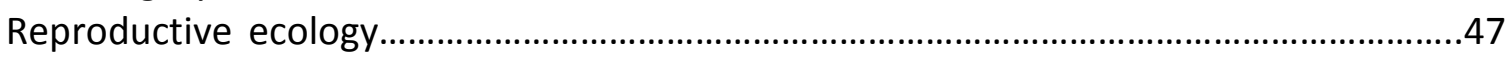

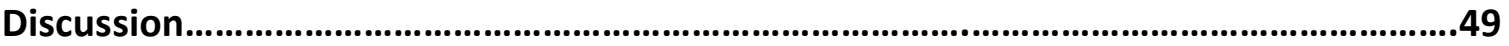

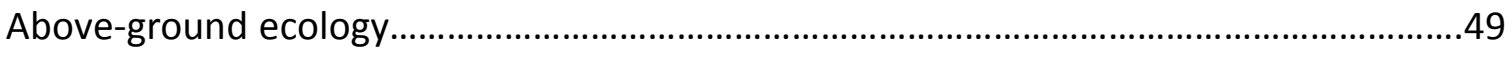

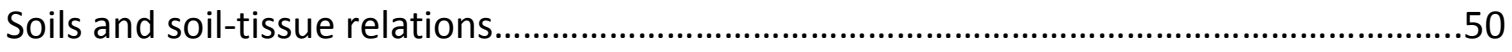

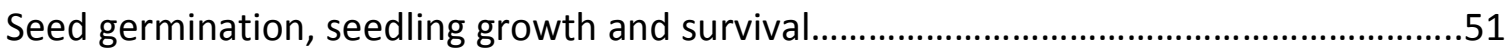

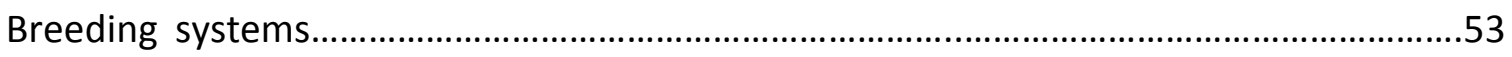

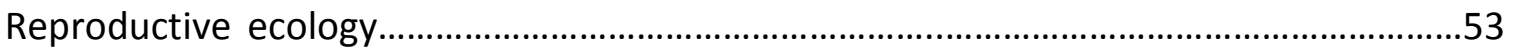

\section{CHAPTER THREE}

INTRASPECIFIC VARIATION IN A RARE BODENVAG......................................................56

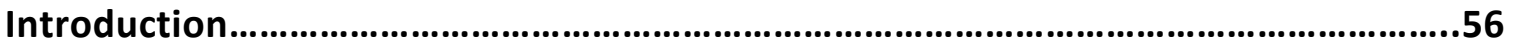

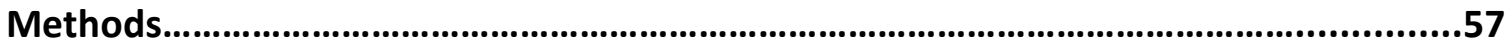

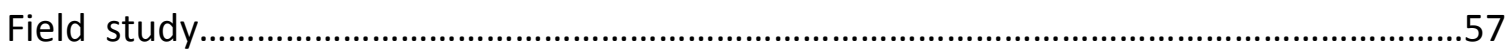

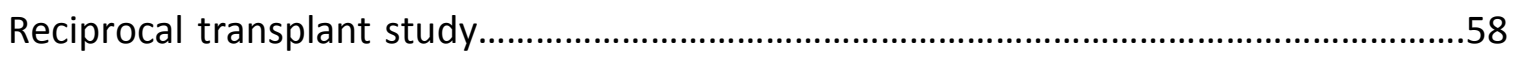

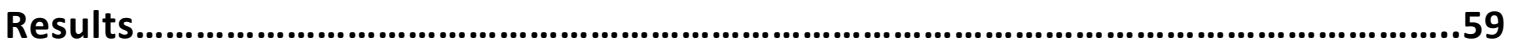

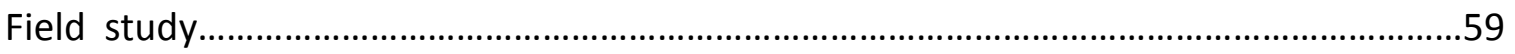

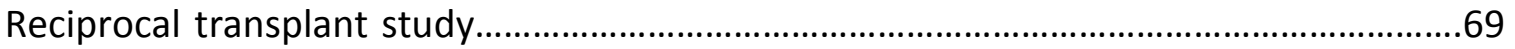

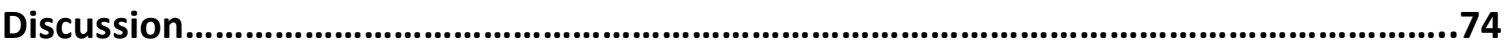

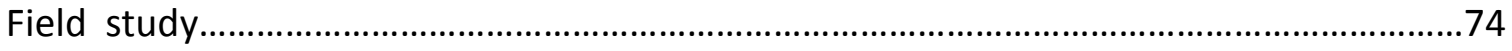

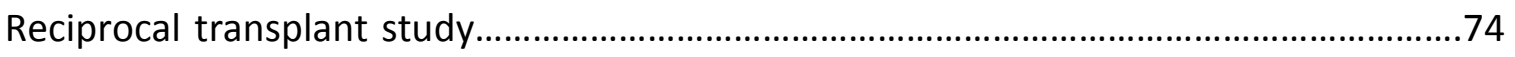

\section{CHAPTER FOUR}

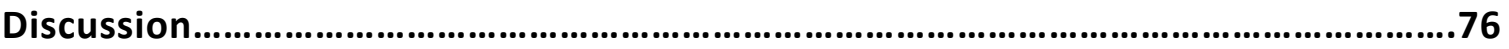

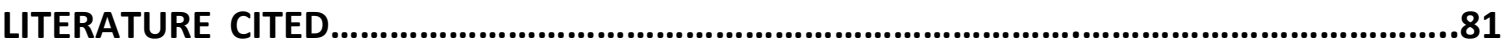




\section{LIST OF TABLES}

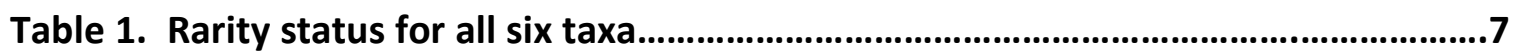

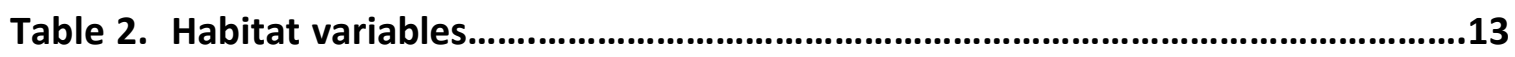

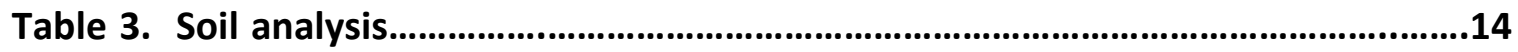

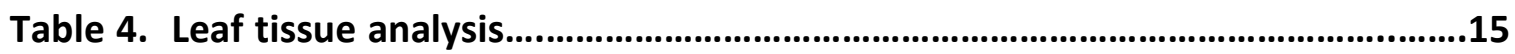

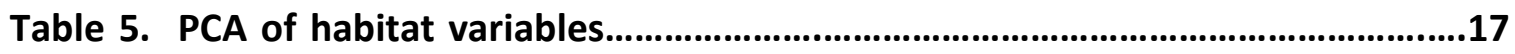

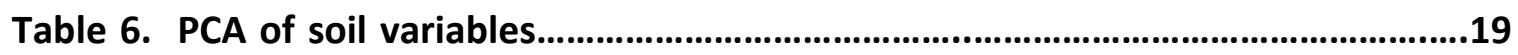

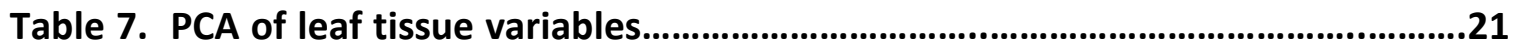

Table 8. Habitat variables for the Monardellas..............................................................32

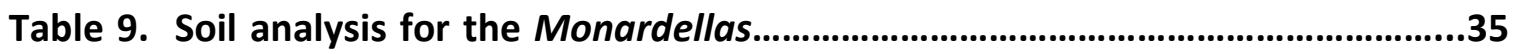

Table 10. PCA of soil variables for the Monardellas...............................................37

Table 11. Leaf tissue analysis for the Monardellas................................................38

Table 12. PCA of leaf tissue variables for the Monardellas.......................................40

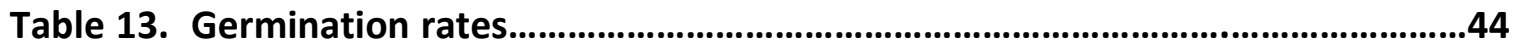

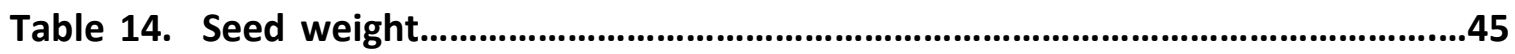

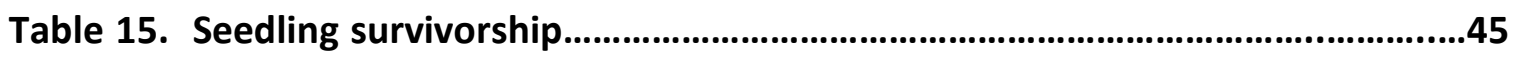

Table 16. Size measurements for the Monardellas.....................................................46

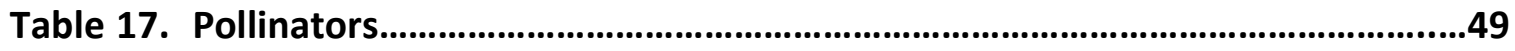

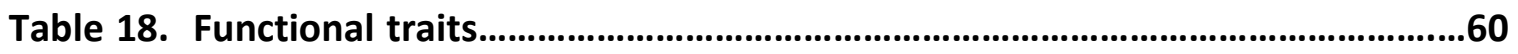

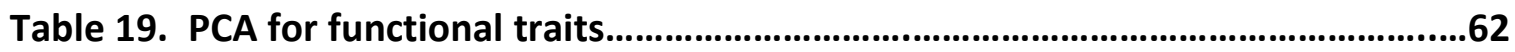


Table 20. Soil analysis for Lewisia cantelovii..........................................................63

Table 21. PCA of soil variables for Lewisia cantelovii.................................................65

Table 22. Habitat variables for Lewisia cantelovii................................................67

Table 23a. Size measurements for Lewisia cantelovii (1).............................................70

Table 23b. Comparison of size measurements (1)....................................................70

Table 24a. Size measurements for Lewisia cantelovii (2).........................................71

Table 24b. Comparison of size measurements (2)......................................................71 


\section{LIST OF FIGURES}

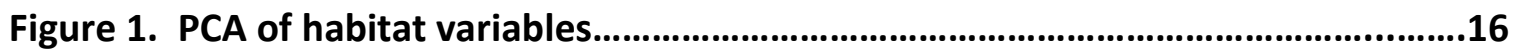

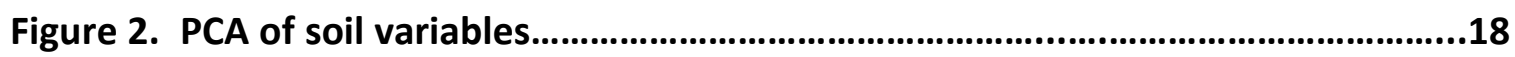

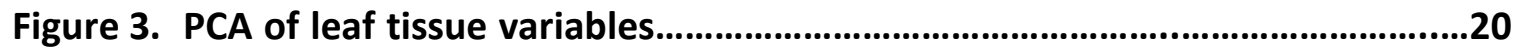

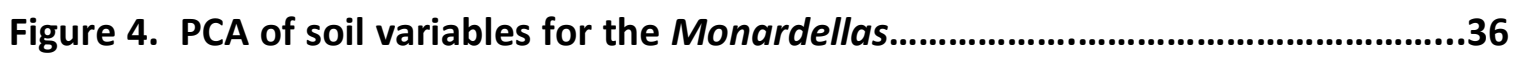

Figure 5. PCA of leaf tissue variables for the Monardellas......................................39

Figure 6. Linear regression - Monardella stebbinsii .................................................41

Figure 7. Linear regression - Monardella follettii.......................................................42

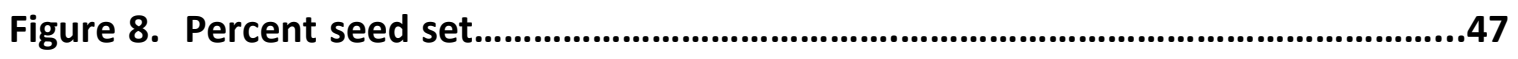

Figure 9. Pollinators for Monardella stebbinsii...............................................................48

Figure 10. Pollinators for Monardella follettii...............................................................48

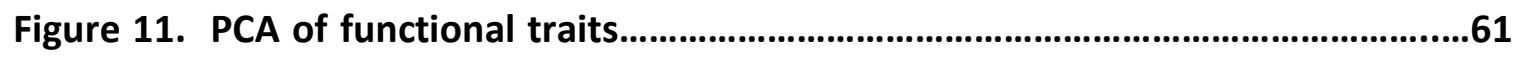

Figure 12. PCA of soil variables for Lewisia cantelovii............................................64

Figure 13. Temperature...................................................................................................68

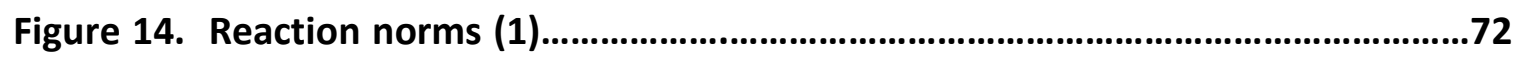

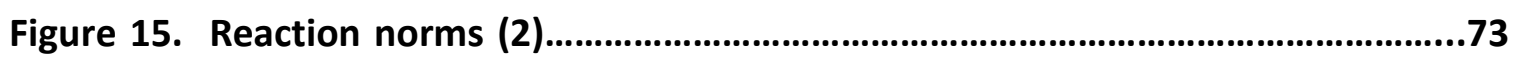




\section{CHAPTER ONE RARE PLANTS OF PLUMAS NATIONAL FOREST}

Introduction - Common species are by their nature easier to study, and potentially more ecologically important, yet rare species contribute a great deal to Earth's biodiversity. In order to be informed for best management practices to protect these resources, it is critical to have a basic understanding of these rare organisms (Kunin and Gaston, 1993).

Humans have long been fascinated with rarity. Whether it is a rare piece of art, a rare coin, or a rare organism, things that are rare are often ranked as more important than their more common counterparts. When we think of a rare species we tend to think of a cute cuddly one like the Giant Panda or another charismatic mega-fauna such as the Cheetah. Unfortunately, when it comes to recognizing and protecting rare plants, they tend to be overlooked. While almost $50 \%$ of the federally listed threatened or endangered species in the United States are plants, they tend to receive a very small percent of the recovery funds spent by the U.S. Fish and Wildlife Service (Schemske et al., 1994).

Stebbins proposed two theories to explain why plants are rare. One implies that rare species are young in an evolutionary sense and have not yet had time to spread throughout their potential range (i.e., neoendemic). The other theory implies that rare species are old evolutionarily and their populations are exhibiting biotype depletion 
(i.e.,paleoendemic) where their genetic stock may be dwindling and are on a natural path to extinction (Stebbins, 1942, 1980).

Mills and Schwartz (2005), point out that species with narrow distributions, whether containing large or small population sizes, are usually endemic species. In contrast, those that have a wide distribution but are sparse throughout their range are considered "suffusively" rare species. They found that only $2 \%$ of the species in the North American Flora are suffusively rare while over $22 \%$ are endemic, and around $20 \%$ of all plants in North America are rare in some sense of the word. Suffusively rare species have distinctive life-history traits including being found in bogs, being monocots, and being seedless vascular plants. Endemic species tended to be shrubs and were more often able to exhibit plasticity in their growth form (Mills and Schwartz, 2005).

In a similar study by Harper (1979), it was found that shrubs were underrepresented on lists of rare and endangered plants while herbaceous species were in abundance. In addition, plants that had flowers with bilateral symmetry were very common among rare and endangered taxa. This final observation points to the conclusion that the species with this trait are most likely reliant on specific pollinators to reproduce (Harper, 1979).

When it comes to taxonomic recognition of rare species there are times when varieties or ecotypes of a species go unrecognized even though they may be rare (Kruckeberg and Rabinowitz, 1985). The serpentine endemic Streptanthus polygaloides (Brassicaceae) is an example of a plant that is relatively common throughout the 
foothills of the Sierra Nevada mountain range, yet the species contains four distinct sepal morphotypes; none of these color morphs get any special protection or taxonomic recognition (Boyd et al., 2009). Although this is an example of diversity that is visible to the naked eye, it is also important to pay attention to cryptic forms of diversity that may otherwise go unnoticed (e.g., genetic), especially if these species are rare.

Over $44 \%$ of all vascular plant species worldwide are endemic to one of the 25 hotspots of biodiversity that cover less than $2 \%$ of the land surface on Earth (Myers et al., 2000). California is one of those hotspots, and serpentine outcrops within the state play host to much of the States biodiversity. Over 30\% of taxa found in California are endemic to the state (Raven and Axelrod, 1978). Serpentine in California covers just $1.5 \%$ of the landmass, yet almost half of the plant species endemic to the State double as serpentine endemics (Kruckeberg, 1984, Safford et al., 2005). Similar patterns are found throughout the world on serpentine outcrops (Thorne et al., 2011).

There are many morphological adjustments (i.e., adaptations) that plants show in response to serpentine. Included in these responses are xeromorphisms such as reduction in overall plant size or in individual above ground structures, increased pubescence, sclerophylly, glaucousness and an increase in the size of the root system. Although many physiognomic differences can be seen between serpentine and nonserpentine vegetation, the most noticeable difference between vegetation growing on the two soil types is that there is an abrupt change in vegetation types (Kruckeberg, 1984). 
The term "serpentine" is generally used by non-geologists to refer to soils derived from ultramafic rocks (Kruckeberg, 1984). Ultramafics are mantle rocks that have been uplifted and contain at least 70\% ferromagnesian minerals (Brady et al., 2005). In California, ultramafics are mainly serpentinite and peridotite (Alexander, 2009). Serpentine soils provide a harsh environment for plant growth by having a low $\mathrm{Ca} / \mathrm{Mg}$ molar ratio $(<1)$, being mostly low in essential nutrients, and having a high concentration of heavy metals (particularly Ni) that are toxic to plants (Kazakou et al., 2008). Serpentine soils host high rates of endemic species (Kruckeberg, 1984, Safford et al., 2005), low rates of plant productivity, and vegetation types that are distinct from those on surrounding non-serpentine substrates (Brady et al., 2005). Partly due to their small geographic range, serpentine endemic plant species are greatly overrepresented on the list of California's rare and endangered plants (Safford et al., 2005). Due to the unique conditions that harbor specially adapted species and the patchy or island-like distribution of serpentine throughout California, the species growing on these ultramafic outcrops provide an excellent means to examine the causes and consequences of plant rarity.

Rare plants are more likely to be found in "unique" habitats than in "normal" habitats (Kruckeberg and Rabinowitz, 1985), and serpentine outcrops are a unique habitat for plants found throughout the world (Brooks, 1987; Roberts and Proctor, 1992). Due to the patchy distribution of many rare serpentine endemic plants, there is a 
need for more small preserves and other means of conservation than are necessary for rare plants growing on normal soils (Thorne et al., 2011).

Particular interest is given to rare species because they are at a greater risk of extinction and play a key role in contributing to Earth's biodiversity (Myers et al., 2000). Conservation of rare plant species is an issue of concern that has held great importance for ecologists over the years (Drury, 1980; Schemske et al., 1994; Bevill and Louda, 1999; Mills and Schwartz, 2005; Sadler and Bradfield, 2010). In order to conserve rare plants and inform landowners how best to manage for these species, it is critical to be informed about their biology and ecology (Stebbins, 1980; Kruckeberg and Rabinowitz, 1985; Schemske et al., 1994; Bevill and Louda, 1999). Here, I will examine the biology and ecology of six rare plants found in Plumas National Forest with detailed studies on three of the plants found on serpentine. In describing the natural history of these six species, I looked at reproductive biology (including seed set, reproductive strategy, and pollinators), germination rates, below ground ecology, above ground ecology, and ion uptake.

The six study taxa are Clarkia mildrediae (A. Heller) H. Lewis and M. Lewis subsp. mildrediae (Mildred's Clarkia; Onagraceae), Cypripedium californicum A. Gray (California lady's slipper), Cypripedium fasciculatum Kellogg (clustered lady's slipper; Orchidaceae), Monardella stebbinsii Hardham and Bartel (Stebbin's Monardella), Monardella follettii (Jeps.) Jokerst (Follett's Monardella; Lamiaceae), and Lewisia cantelovii J.T. Howell (Cantelow's Lewisia; Montiaceae). All species are endemic to California with the 
exception of Cypripedium fasciculatum, which is found scattered throughout the Western United States (USDA/NRCS 2011). Aside from the two orchid species, there is almost no published literature on the biology of these rare plants and baseline data are crucial for better management of these taxa.

Methods - Study area and taxa - Plumas National Forest (Lat 39 $54^{\prime} 56^{\prime \prime} \mathrm{N}$, Lon $\left.121^{\circ} 50^{\prime} 24^{\prime \prime} \mathrm{W}\right)$ covers 46,3800 hectares in the Northern Sierra Nevada, California just south of the Cascade Range. Elevations range from about 610 to $2440 \mathrm{~m}$. The average annual minimum temperature from 1985 to 2010 was $0^{\circ} \mathrm{C}$ and the maximum was $19^{\circ} \mathrm{C}$. Average total annual precipitation is $103.1 \mathrm{~cm}$ and average total snowfall is $139.4 \mathrm{~cm}$ (California Climate Data Archive http://www.calclim.dri.edu/data.html, Quincy, CA). The six taxa chosen for study are all United States Forest Service (USFS) Region 5 sensitive species and are found in Plumas National Forest. They include two geophytes (Cypripedium californicum and Cypripedium fasciculatum), two woody perennials (Monardella stebbinsii and Monardella follettii), one semi-succulent perennial (Lewisia cantelovii) and one annual (Clarkia mildrediae subsp. mildrediae). The rarity status for all six taxa is listed in Table 1. 
Table 1. Rarity status for all six taxa.

\begin{tabular}{lccc}
\hline & CNPS & Global & State \\
\hline Clarkia mildrediae subsp. mildrediae & $1 \mathrm{~B} .3$ & $\mathrm{G} 3$ & $\mathrm{~S} 3.3$ \\
Cypripedium californicum & 4.2 & $\mathrm{G} 3$ & $\mathrm{~S} 3.2$ \\
Cypripedium fasciculatum & 4.2 & $\mathrm{G} 4$ & $\mathrm{~S} 3.2$ \\
Lewisia cantelovii & $1 \mathrm{~B} .2$ & $\mathrm{G} 3$ & $\mathrm{~S} 3.2$ \\
Monardella follettii & $1 \mathrm{~B} .2$ & $\mathrm{G} 2$ & $\mathrm{~S} 2$ \\
Monardella stebbinsii & $1 \mathrm{~B} .2$ & $\mathrm{G} 1$ & $\mathrm{~S} 1.2$ \\
\hline
\end{tabular}

Notes: The rankings mean the following; CNPS list - 1B "rare, threatened or endangered in California or elsewhere", 0.2 "fairly endangered in California", 0.3 "not very endangered in California". 4 "limited distribution (watch list)". Global rank - G1 "critically imperiled", G2 "imperiled", G3 "vulnerable", G4 "apparently secure". State rank - S1.2 "less than 6 occurrences or less than 1,000 individuals or less than 2,000 acres", S2 "6-20 occurrences or $1,000-3,000$ individuals or 2,000-10,000 acres", S3.2 "21-80 occurrences or 3,000-10,000 individuals or 10,000-50,000 acres", S3.3 "21-80 occurrences or 3,000-10,000 individuals or 10,000-50,000 acres".

Above-ground ecology and soil-tissue ion relations - Five sites per species and five individual plants per site were sampled. At each site, general habitat characteristics were measured including slope, aspect, and percent cover of rock, boulder, duff, shrubs and herbaceous species. All plant species found at each site were recorded.

Microhabitat characteristics were recorded at each of the five plants per site, including canopy cover using a convex spherical crown densitometer (Forestry Suppliers, Inc., Jackson, Mississippi), light intensity using a Quantum Meter (Model MQ-100 Apogee Instruments Inc., Logan, Utah), and soil moisture using a FieldScout@ TDR 200 soil moisture meter (Spectrum Technologies, Inc., Plainfield, Illinois). In addition, phenology of each plant (whether it was in fruit, flower, or bud) was recorded and the number of reproductive units (fruits, flowers, or buds) was counted. Descriptive statistics were conducted on all six taxa and Principle Components Analysis (PCA) was 
performed in order to observe separation of the taxa in multivariate space. All data were checked for parametry and skewed data was log transformed (Systat 12, Chicago, Illinois).

All sites were located using shapefiles of USFS known populations and a Trimble (Sunnyvale, California) GPS unit (Juno in 2009 and GeoXM in 2010). Field rhizospheric soil and leaf tissue were collected during the summer of 2009. Two hundred g of soil was dug from the rhizosphere of each plant using a stainless steel hand trowel. Fortyfive grams (dry weight) of leaf tissue was collected from the upper portion of each plant so as to avoid as little soil contamination as possible. Soil and tissue samples were pooled into one sample per population for all taxa except the two Monardellas in which all samples were analyzed separately. This was done in order to conduct detailed studies on the Monardellas and broad studies on the other four taxa, and due to limited funding for soil and tissue analysis.

Soil samples were air dried in a lab at San José State University and rocks were removed by hand. Samples were then sent to $A$ and L Western Agricultural Laboratory (Modesto, California, Stanislaus County) for analysis. Organic matter values were obtained using the loss of ignition method at $360^{\circ} \mathrm{C}$. Extractable Potassium, Calcium, Magnesium and Sodium were obtained using $1.0 \underline{\mathrm{N}}$ ammonium acetate at a $\mathrm{pH}$ of 7.0. Cation Exchange Capacity (CEC) was measured using the Ammonium Replacement method or computed according to the sum of meq K, Mg, $\mathrm{Ca}, \mathrm{Na}$ and $\mathrm{H} / 100 \mathrm{~g}$ of soil and $\mathrm{pH}$ was measured using the saturated paste method (Gavlak et al., 2003). Values for $\mathrm{Ni}$, 
$\mathrm{Zn}, \mathrm{Mn}, \mathrm{Fe}, \mathrm{Cu}$ and Mo were obtained by extraction with $0.005 \mathrm{M}$ diethylene triamine pentaacetic acid (DTPA) buffered with triethanolamine to pH 7.3 (Lindsay and Norvell, 1978).

Leaf samples were washed in the field in $0.1 \mathrm{M} \mathrm{HCl}$, rinsed three times in distilled water and then oven dried for 48 hours at $70^{\circ} \mathrm{F}$. Tissue was sent to the University of Maine (Orono, ME) Analytical Laboratory for analysis where it was ground and elemental concentrations determined by the dry-ashing method and detected by ICPOES.

Breeding systems and germination - Knowing if sensitive species are selfcompatible or obligate outcrossers can help managers to better understand the reason for a decrease in fitness should one occur (Ellstrand and Elam, 1993). Six plants from six populations of Lewisia cantelovii, Monardella stebbinsii, M. follettii, and Clarkia mildrediae subsp. mildrediae were randomly selected to determine if the species are predominantly selfers or outcrossers. Bags made of thin white cloth and closed at the bottom with velcro were placed on budding flowers. These were collected two months later when the plant was in fruit along with an un-bagged fructescence from each plant whenever possible. Mature seeds were counted in all fruits collected and divided by the number of flowers to get percent seed set. Seeds were determined as mature when black in Lewisia and brown to dark brown in the other three taxa. Percent seed set was compared in bagged vs. un-bagged fruits using a two sample $t$-test (Microsoft Excel 
2007, Redmond, Washington). Results for the two Monardellas are reported in Chapter two.

Seeds were collected from a randomly chosen population of Clarkia mildrediae subsp. mildrediae and two sets of 20 seeds (representing 10 different mothers) were germinated in two $15 \mathrm{~cm}$ petri dishes. Seeds were removed from the capsules and placed in a petri dish with wet soil for germination with no cold stratification treatment. Separate and more detailed studies were conducted on the two Monardellas and the Lewisia. With the exception of the PCA all results shown below only include the two Cypripediums and the Clarkia. Data on the two Monardellas and the Lewisia are displayed in chapters two and three but all taxa were included in the PCA in order to show the separation of all six species together in PCA space.

\section{Results - Above-ground ecology and soil-tissue ion relations - Clarkia} mildrediae subsp. mildrediae (CLMIM) is found in dry (Table 3), open (average canopy cover was $24 \%$, Table 2) yellow pine forests. The majority of the CLMIM sites visited were composed of granitic soils with one population being found near a serpentine contact zone, although CLMIM did not occur on the serpentine. Slopes range from $55 \%$ to $75 \%$ and almost all aspects are represented (Table 2).

Dominant species found at CLMIM sites include Pinus ponderosa Douglas ex Lawson and C. Lawson (Ponderosa Pine; Pinaceae), Pseudotsuga menziesii (Mirb.) Franco (Douglas-Fir; Pinaceae), Calocedrus decurrens (Torr.) Florin (Incense Cedar; Cupressaceae), Quercus chrysolepis Liebm. (Canyon Live Oak; Fagaceae), Quercus 
garryana Hook. var. breweri (Engelm.) Jeps. (Brewer's Oak; Fagaceae), Acer macrophyllum Pursh (Big-Leaf Maple; Sapindaceae), and Ceanothus integerrimus Hook. and Arn. (Deer Brush; Rhamnaceae). Other associates include Quercus kelloggii Newb. (Black Oak; Fagaceae), Mimulus aurantiacus Curtis (Sticky Monkeyflower; Phrymaceae), Cornus nuttallii Audubon (Mountain Dogwood; Cornaceae), Ribes roezlii Regel (Sierran Gooseberry; Grossulariaceae), Asyneuma prenanthoides (Durand) McVaugh (Harebell; Campanulaceae) Draperia systyla (A. Gray) Torr. Ex A. Gray (Draperia; Boraginaceae), Eriogonum nudum Douglas ex Benth. (Naked Buckwheat; Polygonaceae), Pteridium aquilinum (L.) Kuhn (Bracken Fern; Dennstaedtiaceae), Castilleja sp. (Indian Paintbrush; Orobanchaceae), and Lupinus dalesiae Eastw. (Quincy Lupine; Fabaceae).

CYCA is found in serpentine fens and seeps making its habitat extremely wet (roots often completely inundated with water year round, Table 3) with high canopy cover (average $53 \%$, Table 2). It is found on gentle slopes that range from $15 \%$ to $50 \%$ and on almost all aspects (Table 2).

While CYCA grows at very wet sites with high organic matter (Table 3 ), it shows harsh conditions in its soil content as it is high in heavy metals $(\mathrm{Ni}, \mathrm{Mg}, \mathrm{Fe}, \mathrm{Cu})$, low in essential nutrients for plant growth $(\mathrm{P}, \mathrm{Ca})$, and has a low $\mathrm{Ca} / \mathrm{Mg}$ ration $(<1)$ in comparison to the other two taxa shown (Table 3). Similar patterns are shown in the tissue content of these plants (Table 4).

Dominant species found at CYCA sites include Rhododendron occidentale (Torr. and A. Gray) A. Gray (California Azalea; Ericaceae), Calocedrus decurrens and 
Pseudotsuga menziesii. Other species associated with CYCA include Hastingsia alba (Durand) S. Watson (White Schoenolirion; Agavaceae), Aquilegia formosa Fisch. ex DC. (Crimson Columbine; Ranunculaceae), Adiantum aleuticum (Rupr.) C. A. Paris (FiveFinger Fern; Pteridaceae), Lilium pardalinum Kellogg subsp. pardalinum (Leopard Lily; Liliaceae), Angelica breweri A. Gray (Brewer's Angelica; Apiaceae), Epipactis gigantea Douglas (Stream Orchid; Orchidaceae), and at one site it was found growing with the carnivorous Darlingtonia californica Torr. (California Pitcher Plant; Sarraceniaceae).

CYFA was found growing in dense, moist coniferous forest almost always directly under Cornus nuttallii with large Pseudotsuga menziesii nearby and with little competing herbaceous vegetation (Table 2, Table 3). Average canopy cover at CYFA sites is $89 \%$, and it is found on gentle slopes that range from $10 \%$ to $42 \%$ on all aspects (Table 2 ).

Dominant species associated with CYFA are Cornus nuttallii and Pseudotsuga menziesii. Other associated species include Abies concolor (Gordon and Glend.) Lindl. ex Hildebr. (White Fir; Pinaceae), Pinus lambertiana Douglas (Sugar Pine; Pinaceae), Chrysolepis sempervirens (Kellogg) Hjelmq. (Bush Chinquapin; Fagaceae), Adenocaulon bicolor Hook. (Trail Plant; Asteraceae), Symphoricarpos mollis Nutt. (Creeping Snowberry; Caprifoliaceae), Trientalis latifolia Hook. (Starflower; Myrsinaceae), and Amelanchier utahensis Koehne (Service-Berry; Rosaceae). 
Table 2. Habitat variables.

\begin{tabular}{cccc}
\hline $\begin{array}{c}\text { Habitat } \\
\text { Variable }\end{array}$ & CLMIM & CYCA & CYFA \\
\hline Slope & $66 \pm 4(55-75)$ & $36 \pm 6(15-50)$ & $27 \pm 6(10-42)$ \\
Aspect & $121 \pm 42(20-270)$ & $187 \pm 45(80-315)$ & $282 \pm 65(20-360)$ \\
Percent Rock & $36 \pm 10(10-75)$ & $41 \pm 9(20-75)$ & $20 \pm 5(10-40)$ \\
Percent Boulder & $7 \pm 2(1-15)$ & $47 \pm 8(20-70)$ & $5 \pm 3(0-20)$ \\
Percent Duff & $40 \pm 11(5-65)$ & $73 \pm 10(35-90)$ & $85 \pm 7(60-100)$ \\
Percent Shrub & $40 \pm 11(5-75)$ & $58 \pm 7(40-85)$ & $42 \pm 8(30-70)$ \\
Percent Herb & $36 \pm 17.8(15-55)$ & $69 \pm 13.8(50-85)$ & $35 \pm 25.9(20-80)$ \\
Canopy Cover & $24 \pm 10(0-40)$ & $53 \pm 15(6-88)$ & $89 \pm 6(63-96)$ \\
Light Intensity & $1011 \pm 457(61-2110)$ & $592 \pm 316(9-1702)$ & $341 \pm 165(13-865)$ \\
\hline
\end{tabular}

Notes: Values displayed are averages of the five sites visited per species. Slope and canopy cover are in percent and aspect is in degrees. Values listed are as follows: mean \pm SE (range). For canopy cover and light intensity $n=25$ (measurement taken at 5 individuals $\times 5$ sites per species) and for all other variables $n=5$ (one measurement taken per site). 
Table 3. Soil analysis.

\begin{tabular}{cccc}
\hline $\begin{array}{c}\text { Soil } \\
\text { Variable }\end{array}$ & CLMIM & CYCA & CYFA \\
\hline $\mathrm{OM}$ & $5.02 \pm 1.19(2.4-8.7)$ & $14.94 \pm 6.39(4.7-39.1)$ & $8.9 \pm 2.79(5-19.9)$ \\
$\mathrm{P}$ & $38.48 \pm 14.61(11-92)$ & $6.3 \pm 3.1(1.1-18)$ & $39.86 \pm 21.82(1.4-106)$ \\
$\mathrm{pH}$ & $6.24 \pm 0.14(5.8-6.7)$ & $7.42 \pm 0.16(7-8)$ & $6.5 \pm 0.17(6.1-7.1)$ \\
$\mathrm{K}$ & $102.44 \pm 28.52(36.3-181.1)$ & $107.42 \pm 19.71(57.6-177.5)$ & $344.16 \pm 57.88(232.3-556.2)$ \\
$\mathrm{Ca}$ & $810.66 \pm 256.09(199-1328)$ & $593.52 \pm 116.78(406-1050)$ & $1832.2 \pm 287.18(1016-2571)$ \\
$\mathrm{Mg}$ & $275.04 \pm 193.99(23.4-1039)$ & $2202.6 \pm 171.47(1669-2749)$ & $181.3 \pm 54.19(77.3-387.4)$ \\
$\mathrm{Ca} / \mathrm{Mg}$ & $7.38 \pm 2.04(1.3-14)$ & $0.2 \pm 0.04(0.2-0.4)$ & $11.7 \pm 1.7(6.6-15.7)$ \\
$\mathrm{Na}$ & $13.1 \pm 1.5(10.6-17.7)$ & $19.1 \pm 2.39(12.4-25)$ & $10.94 \pm 0.35(10.3-12.3)$ \\
$\mathrm{CEC}$ & $7.26 \pm 2.76(1.6-16.3)$ & $21.4 \pm 1.98(16.1-28.4)$ & $12.4 \pm 1.75(7.2-17)$ \\
$\mathrm{S}$ & $2.14 \pm 0.81(0.6-4.9)$ & $9.98 \pm 3.9(3.9-25.7)$ & $4.56 \pm 0.91(2.2-6.6)$ \\
$\mathrm{Ni}$ & $6.16 \pm 5.96(0.10-30.0)$ & $35.2 \pm 10.1(13.3-65.5)$ & $0.26 \pm 0.06(0.1-0.5)$ \\
$\mathrm{Zn}$ & $0.56 \pm 0.17(0.2-1.2)$ & $1.92 \pm 0.66(0.5-4.3)$ & $0.7 \pm 0.14(0.4-1.2)$ \\
$\mathrm{Mn}$ & $42.2 \pm 11.6(8-62)$ & $26 \pm 11.76(10-72)$ & $29.4 \pm 5.38(18-45)$ \\
$\mathrm{Fe}$ & $30.2 \pm 7.65(13-51)$ & $45 \pm 12.54(11-86)$ & $24 \pm 6.38(10-45)$ \\
$\mathrm{Cu}$ & $0.34 \pm 0.09(0.1-0.6)$ & $1.16 \pm 0.22(0.6-1.8)$ & $0.2 \pm 0.05(0.1-0.4)$ \\
$\mathrm{Moisture}$ & $1.02 \pm 0.22(0.1-3.1)$ & $56.36 \pm 3.77(8.1-82.2)$ & $8.02 \pm 1.27(2.1-18.7)$ \\
\hline
\end{tabular}

Notes: Values displayed are pooled samples from five plants and averages of the five sites per species. Organic matter (OM) is in percent, elemental concentrations are measured in $\mu \mathrm{g} \mathrm{g}^{-1}$ dry soil (ppm), cation exchange capacity (CEC) was measured in meq $100 \mathrm{~g}^{-1}$, and soil moisture was measured in \% volumetric water content. Values listed are as follows: mean \pm SE (range), $\mathrm{n}=\mathbf{2 5}$ for soil moisture and $\mathrm{n}=5$ for all other variables. 
Table 4. Leaf tissue analysis.

\begin{tabular}{cccc}
\hline $\begin{array}{c}\text { Tissue } \\
\text { Variable }\end{array}$ & CLMIM & CYCA & CYFA \\
\hline $\mathrm{K}$ & $13120 \pm 1388.4(8784-17178)$ & $19028 \pm 1141.8(15846-21347)$ & $21528 \pm 1000(18731-24917)$ \\
$\mathrm{Ca}$ & $14701 \pm 2014.9(9156-19342)$ & $3309.2 \pm 811.9(1595-5559)$ & $11156 \pm 937.34(8803-13628)$ \\
$\mathrm{Mg}$ & $2683.8 \pm 453.1(1863-4425)$ & $4904.8 \pm 622.3(3349-6495)$ & $1856.2 \pm 96.29(1613-2152)$ \\
$\mathrm{Ca} / \mathrm{Mg}$ & $6.36 \pm 1.47(2.1-10)$ & $0.72 \pm 0.19(0.2-1.4)$ & $6.12 \pm 0.74(4.5-8.4)$ \\
$\mathrm{P}$ & $1628.4 \pm 207.56(1274-2377)$ & $1629 \pm 125.7(1320-1967)$ & $1974.8 \pm 166.44(1416-2427)$ \\
$\mathrm{Al}$ & $141.9 \pm 24.32(83.5-217)$ & $65.6 \pm 19.06(31.9-140)$ & $62.26 \pm 4.75(46.9-75.7)$ \\
$\mathrm{B}$ & $19.84 \pm 2.27(13.3-26.6)$ & $20.48 \pm 2.16(15.4-26.7)$ & $15.42 \pm 2.92(8.4-26.1)$ \\
$\mathrm{Cu}$ & $5.09 \pm 1.27(2.47-9.41)$ & $6.02 \pm 0.71(4.44-8.41)$ & $6.58 \pm 0.51(5.1-8.1)$ \\
$\mathrm{Fe}$ & $142.84 \pm 26.26(84.2-222)$ & $170.08 \pm 56.79(73.4-391)$ & $79.76 \pm 6.38(63.6-98.3)$ \\
$\mathrm{Mn}$ & $169.54 \pm 42.12(76.1-300)$ & $23.22 \pm 5.64(14.3-45.2)$ & $45.52 \pm 8.55(26-73.3)$ \\
$\mathrm{Zn}$ & $30.76 \pm 3.09(19.6-37.1)$ & $22.68 \pm 2.67(15.8-29)$ & $24.18 \pm 1.38(18.8-26.3)$ \\
$\mathrm{Na}$ & $82.02 \pm 19.37(27.8-126)$ & $99.12 \pm 19.73(47.7-167)$ & $268.2 \pm 51.58(121-425)$ \\
$\mathrm{Ni}$ & $5.34 \pm 3.69(1.02-12.7)$ & $28.96 \pm 9.44(4.5-52.8)$ & $1.57 \pm 0.69(0.44-3.9)$ \\
\hline
\end{tabular}

Notes: Values displayed are pooled samples from five plants and averages of the five sites per species. Measurement units are in $\mu \mathrm{g} \mathrm{g}^{-1}$ dry tissue and values listed are as follows: mean $\pm \mathrm{SE}$ (range), $\mathrm{n}=5$.

The PCA for habitat variables (Figure 1, Table 5) had $47 \%$ of the variance explained by the first principle component which was influenced by slope, aspect, percent boulder, percent duff, percent cover of shrubs, percent cover of herbaceous species, and percent canopy cover (Table 5). The second principle component explained $15 \%$ of the variance and was mainly influenced by percent rock, percent shrub, and percent herbaceous cover (Table 5).

For the PCA of soil variables, the first and second principle components explained $24 \%$ and $22 \%$ of the variance, respectively (Figure 2 , Table 6 ). The first component was influenced by $\mathrm{pH}, \mathrm{K}, \mathrm{Ca} / \mathrm{Mg}$ ratio, $\mathrm{S}, \mathrm{Zn}, \mathrm{Mn}, \mathrm{Fe}$ and $\mathrm{Cu}$, whereas the second component was influenced by soil moisture, organic matter, $\mathrm{P}, \mathrm{pH}, \mathrm{Na}$, cation 
exchange capacity, S, Zn and Cu (Table 6). The PCA for tissue variables (Figure 3, Table 7) had $34 \%$ and $20 \%$ of the variance explained by the first two principle components.

The first component was influenced by $\mathrm{K}, \mathrm{Ca} / \mathrm{Mg}$ ratio, $\mathrm{P}, \mathrm{Al}, \mathrm{B}, \mathrm{Cu}, \mathrm{Na}$, and $\mathrm{Ni}$ whereas the second principle component was influenced by $\mathrm{Mn}, \mathrm{Al}, \mathrm{Zn}$, and B (Table 7).

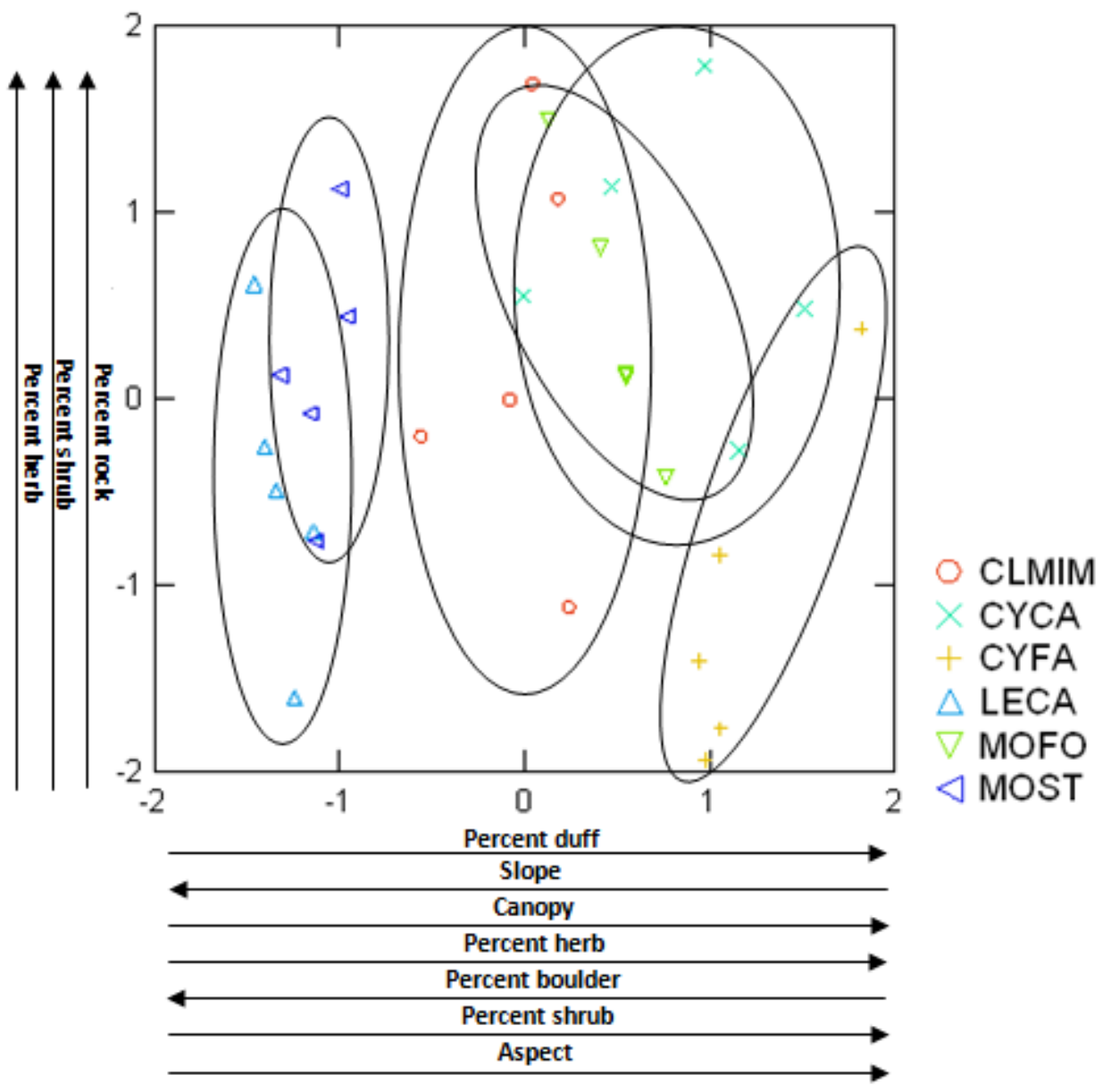

Figure 1. PCA of habitat variables.

Notes: The $x$-axis is PC 1 and the $y$-axis is PC 2. Arrows are in order of the loadings (the closest to the plot being the strongest loading) and their direction (negative or positive). 
Table 5. PCA of habitat variables.

\begin{tabular}{|l|r|r|}
\hline & \multicolumn{1}{|l|}{ PC 1 } & \multicolumn{1}{l|}{ PC 2 } \\
\hline Eigenvalues & \multicolumn{1}{l|}{ 3.819 } & \multicolumn{1}{l|}{1.242} \\
\hline \% variance explained & \multicolumn{1}{|l|}{$\mathbf{4 7 . 7 3 6}$} & \multicolumn{1}{l|}{$\mathbf{1 5 . 5 2 4}$} \\
\hline & Loadings & \multicolumn{1}{l|}{ Loadings } \\
\hline Slope & $-\mathbf{0 . 8 6 9}$ & 0.062 \\
\hline Aspect & $\mathbf{0 . 3 3 8}$ & -0.173 \\
\hline \% Rock & -0.082 & $\mathbf{0 . 8 7 7}$ \\
\hline \% Boulder & $-\mathbf{0 . 7 2 2}$ & 0.062 \\
\hline \% Duff & $\mathbf{0 . 9 1 7}$ & -0.101 \\
\hline \% Shrub & $\mathbf{0 . 6 4 8}$ & $\mathbf{0 . 4 4 6}$ \\
\hline \% Herb & $\mathbf{0 . 7 2 3}$ & $\mathbf{0 . 3 7 2}$ \\
\hline Canopy cover & $\mathbf{0 . 7 9 9}$ & -0.296 \\
\hline
\end{tabular}

Notes: Eigenvalues, percent variance explained and component loadings are shown. Significant loadings are highlighted in bold. 


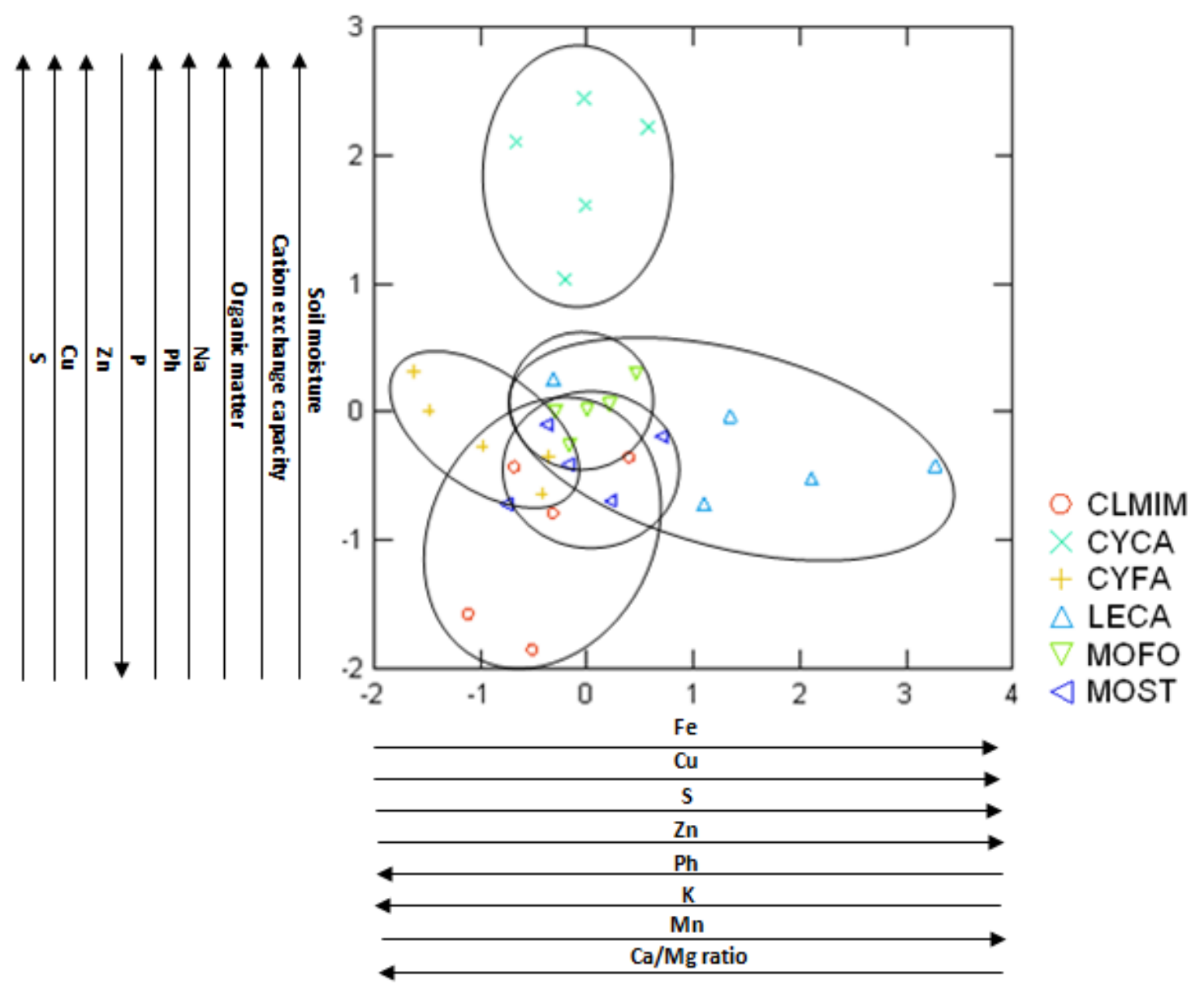

Figure 2. PCA of soil variables.

Notes: The $x$-axis is PC 1 and the $y$-axis is PC 2. Arrows are in order of the loadings (the closest to the plot being the strongest loading) and their direction (negative or positive). 
Table 6. PCA of soil variables.

\begin{tabular}{|c|c|c|}
\hline & PC 1 & PC 2 \\
\hline Eigenvalues & 3.486 & 3.139 \\
\hline \multirow[t]{2}{*}{$\%$ variance explained } & 24.901 & 22.418 \\
\hline & Loadings & Loadings \\
\hline Soil moisture & -0.093 & 0.877 \\
\hline Organic matter & 0.078 & 0.595 \\
\hline$P$ & 0.128 & -0.361 \\
\hline $\mathrm{pH}$ & -0.558 & 0.528 \\
\hline K & -0.489 & 0.253 \\
\hline $\mathrm{Ca} / \mathrm{Mg}$ ratio & -0.329 & 0.251 \\
\hline $\mathrm{Na}$ & 0.034 & 0.573 \\
\hline Cation exchange capacity & -0.291 & 0.846 \\
\hline S & 0.725 & 0.302 \\
\hline $\mathrm{Ni}$ & 0.27 & 0.229 \\
\hline $\mathrm{Zn}$ & 0.697 & 0.342 \\
\hline $\mathrm{Mn}$ & 0.383 & -0.244 \\
\hline Fe & 0.849 & 0.134 \\
\hline $\mathrm{Cu}$ & 0.87 & 0.309 \\
\hline
\end{tabular}

Notes: Eigenvalues, percent variance explained and component loadings are shown. Significant loadings are highlighted in bold. 


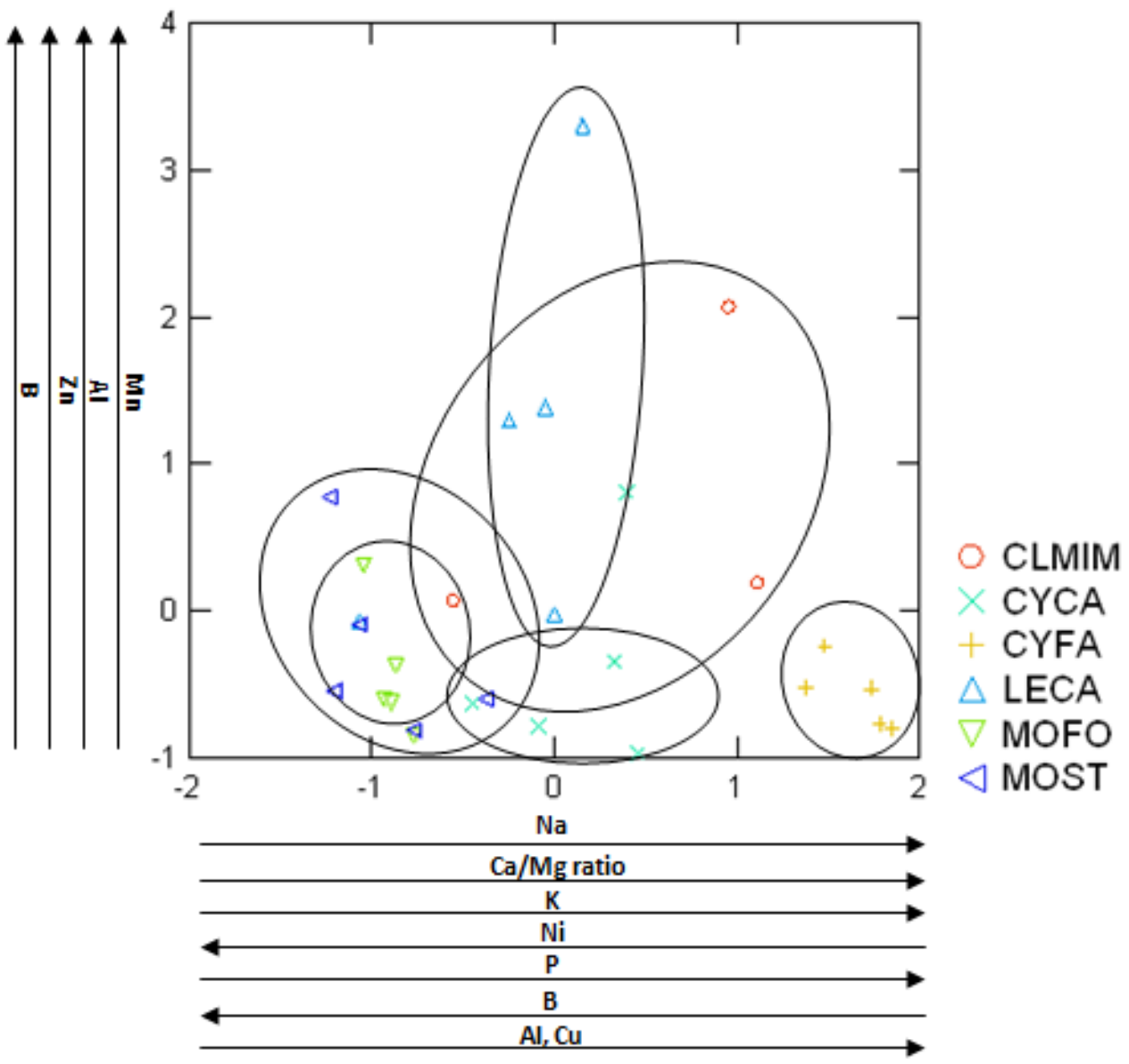

Figure 3. PCA of leaf tissue variables.

Notes: The $x$-axis is PC 1 and the $y$-axis is PC 2. Arrows are in order of the loadings (the closest to the plot being the strongest loading) and their direction (negative or positive). 
Table 7. PCA of leaf tissue variables.

\begin{tabular}{|c|c|c|}
\hline & PC & PC 2 \\
\hline Eigenvalues & 3.843 & 2.286 \\
\hline \multirow[t]{2}{*}{$\%$ variance explained } & 34.938 & 20.784 \\
\hline & Loadings & Loadings \\
\hline K & 0.808 & 0.074 \\
\hline $\mathrm{Ca} / \mathrm{Mg}$ ratio & 0.847 & -0.012 \\
\hline$P$ & 0.785 & -0.232 \\
\hline Al & 0.33 & 0.778 \\
\hline B & -0.41 & 0.448 \\
\hline $\mathrm{Cu}$ & 0.33 & -0.09 \\
\hline $\mathrm{Fe}$ & -0.036 & 0.165 \\
\hline $\mathrm{Mn}$ & 0.091 & 0.906 \\
\hline $\mathrm{Zn}$ & 0.107 & 0.722 \\
\hline $\mathrm{Na}$ & 0.904 & -0.174 \\
\hline $\mathrm{Ni}$ & -0.796 & -0.117 \\
\hline
\end{tabular}

Notes: Eigenvalues, percent variance explained and component loadings are shown. Significant loadings are highlighted in bold.

Breeding systems and germination - Of the 30 plants from five populations bagged for the CLMIM selfing experiment, 23 made it through anthesis. Due to the explosive dehiscence of the CLMIM capsules, I was unable to get an exact seed count on the unbagged specimens, but the fruits of this species produce anywhere between 3070 seeds. Percent fruit set in the bagged specimens was $58 \%$ (SE \pm 0.07 , range $=0-100$, $n=23$ ). Of the 23 plants bagged, three had no fruit set, five had $100 \%$ fruit set and five 
had greater than $70 \%$ fruit set. Both trials for CLMIM germination showed $100 \%$ germination success.

Of the 26 plants from six populations bagged for the LECA selfing experiment, all remained on the plants through anthesis. This was a great success as LECA has very thin, delicate flowering scapes and it appeared unlikely that the bags would last through the flowering season. Fruits of this species produce approximately 2-15 seeds each. Average percent seed set was $3 \%(S E \pm 0.01$, range $=0-33, n=36)$ in bagged specimens and $33 \%(\mathrm{SE} \pm 0.05$, range $=0-100, \mathrm{n}=27)$ in un-bagged specimens and was significantly different when compared using a two sample t-test $(p<0.001)$.

Discussion - Above-ground ecology and soil-tissue ion relations - Out of the three species focused on in this chapter, CYCA, the taxon found on serpentine, shows a low $\mathrm{Ca} / \mathrm{Mg}$ ratio $(<1)$, indicative of the substrate, and higher amounts of heavy metals ( $\mathrm{Cu}, \mathrm{Fe}, \mathrm{Zn}$ and mainly $\mathrm{Ni}$ ) when compared to the other two taxa that are found growing on non-serpentine soils. These results are consistent with studies that have been done throughout California and on various species (Kruckeberg, 1984; Wright et al., 2006). A similar pattern is seen in the tissue with the $\mathrm{Ca} / \mathrm{Mg}$ ratio, $\mathrm{Ni}$ and Fe content but interesting results were seen for $\mathrm{Cu}$ and $\mathrm{Zn}$ in the leaf tissue. Cu was highest in CYFA and Zn was highest in CLMIM but was lowest in CYCA, although opposite patterns were seen in the soil content. These results show that it is possible that CYCA is an excluder of $\mathrm{Cu}$ and $\mathrm{Zn}$ (Baker, 1981). Excluders are plants that are able to refrain from transport of metals to the shoot system over a wide range of metal concentrations in the soil 
(Kazakou et al., 2008). Common garden or hydroponic studies where the amount of these ions are controlled in the soil would need to be conducted in order to say anything conclusive about these differences seen in ion accumulation.

Out of the three PCAs, the one for habitat variables showed the most separation by species in PCA space. Two of the plants found growing on serpentine, MOST and LECA, which grow at very steep and rocky sites (LECA often out of a cliff face), are clustered together where percent slope and percent boulder are high. In contrast, the two orchid species, CYCA and CYFA, are clustered together where slopes are not as steep, canopy cover is high, and the sites are more productive with a higher percent cover of shrubs and herbaceous plants.

Conservation and management plans for rare species often take a single species approach (Carlsen et al., 2002; Ramp Neale et al., 2008; Rechinger et al., 2009), although this may not be the most effective and efficient route (Thorne et al., 2011). While these data may point to the need for a single species approach because all species occupy different habitats, it is important to note that there are other rare taxa found growing in the area that were not included in this study. Plumas National Forest has 62 plants that are listed as rare, sensitive, or endangered (Hanson, 1999). Although the two Cypripedium orchids were outliers that were not found growing with other rare plants, to our knowledge, this was not the case for the five other study taxa.

At most MOFO sites, four other rare plants (Erigeron petrophilus var. sierrensis, Packera eurycephala var. lewisrosei, Frangula purshiana subsp. ultramafica and Arabis 
constancei) were almost always present. Sedum albomarginatum (another rare serpentine endemic) can often be found growing in association with MOST and LECA (at serpentine sites), and Lupinus dalesiae (another rare taxa from Plumas National Forest) can be found growing in association with CLMIM. Due to the sharing of habitat by numerous rare plants, many parts of Plumas National Forest, and, in particular, much of the serpentine, are prime candidates for conservation and preservation of critical habitat.

Breeding systems and germination - In order to manage for rare species, it is critical to understand their reproductive strategy and pollination system as this can have implications for their persistence and survival (Kearns et al., 1998; Carlsen et al., 2002; Sargent and Ackerly, 2008). If persistence of the species is questionable and restoration is warranted, it is imperative to have a basic understanding of the germination requirements so plants can be propagated and brought in to establish new populations (Brumback, 1989; Karlsson and Milberg, 2007). Both of these points are particularly true for rare plants that are found growing on serpentine or other harsh substrates when their habitats become degraded or altered as they will require careful planning in reestablishing the species and restoring its habitat (O'Dell and Claassen, 2011).

Pollen exclosure bag experiments were not conducted on either of the orchid species, but most orchids are believed to be outcrossers due to pollinator specialization (Bernhardt and Edens-Meier, 2010). It is not known what pollinates CYCA but CYFA is pollinated by small wasps. Neither species offers rewards to its pollinators (Lipow et al., 
2002). While germination trials were not conducted on the orchids, members of this family are known for having extremely particular germination requirements as they often require a mycorrhizal symbiont in order to germinate (Shefferson et al., 2005).

Considering many of the bagged CLMIM flowers had 100\% fruit set, it appears to not have a problem selfing. In fact, reproducing does not at all appear to be an issue for this species as it also showed $100 \%$ germination with no pre-treatment for the seeds.

As seen from the bagging experiment, LECA is not able to self. In addition to this field experiment, a plant that was rescued from poachers in the field was observed in the greenhouse at San José State University over two flowering seasons. While it produced many flowers, not a single seed was ever produced, most likely due to lack of pollinators.

These observations are consistent with those of Richerson (1997). She described LECA as an entomophilous (insect pollinated) species that attracts generalist pollinators due to its unspecialized radial flowers. The insects she lists as pollinators for LECA include; Andrena auricoma (Andrenidae), Dialictus sp., Evylaeus sp. (Halictidae), Osmia sp., Protosmia rubifloris (Megachilidae), Xylocopa tabaniformis orpifex (Anthophoridae), Bombus mixtus, B. vosnesenskii, B. melanoygus (Apidae), Paragus sp. (Syrphidae), and Bombylius sp. (Bombyliidae). 


\section{CHAPTER TWO ECOLOGY AND REPRODUCTIVE BIOLOGY OF TWO SERPENTINE ENDEMIC CONGENERS}

Introduction - While the term "serpentine" is usually a blanket term used to clump any soil derived from ultramafic rock, just like with any ecosystem, not all ultramafic outcrops are the same. For example, Alexander (2009) looked at soil and vegetation differences between peridotite and serpentinite outcrops in the Rattlesnake Creek terrane in the Klamath Mountains (Southern Oregon, USA) and found significant differences between the two substrates. Harrison and Inouye (2002) found that within a local serpentine outcrop, $\alpha$ diversity may be low but $\beta$ diversity - turnover across serpentine sites throughout California - is high. When each site contains different species, $\beta$ diversity is highest. This uniqueness on a site-by-site basis creates a challenging situation in regards to conservation planning for California's serpentine flora (Thorne et al., 2011).

This heterogeneity across the serpentine landscape can provide opportunities for niche partitioning among closely related species, which can lead to reproductive isolation. This phenomenon has been shown with the flowering stones in the genus Argyroderma (Aizoaceae) in the South African succulent karoo. This genus is part of the subfamily Ruschioideae, which contains over 1500 species that range in form from small succulent stone plants to large shrubs. It is one of the most impressive examples of adaptive radiation in plants (Klack et al., 2004). Two quartz specialists within the genus were found to be keying in on specific edaphic differences across this unique quartz 
gravel plains landscape (Ellis and Weis, 2006). One of the methods suggested for radiation in this group has been allopatric divergence through use of different microhabitats (Ellis et al., 2006). This could be a potential means of divergence in the two Monardella species as well if differences in the microhabitat and below ground ecology for the two prove to be significantly different.

Specific life-history traits are sometimes known to be associated with plants that have restricted distributions or small isolated populations. Plants that grow in small isolated populations are known to undergo a shift in breeding systems (Kruckeberg and Rabinowitz, 1985; Kunin and Gaston, 1993). On the contrary, in a study by Harper (1979) in which rare plants from Utah, Colorado, and California were examined, it was found that flowers of rare plants tended to have bilateral symmetry, which means they are most likely outcrossers due to pollinator specialization. Sixty-seven percent of flowering plants rely on insects for pollination, and for these outcrossing species, pollinators are as important as light and water (Kearns and Inouye, 1997).

In this portion of my study, I compared the ecology and reproductive biology of two serpentine endemic Monardella species from Northern California, USA. This study included several aspects: 1) above-ground ecology, 2) soils and soil-tissue relations, 3) seed germination, seedling growth, and survival, 4) breeding systems, and 5) reproductive ecology.

Methods - Study area and taxa - The Feather River complex (Lat 39 59' 56" N, Lon $121^{\circ} 7^{\prime} 26^{\prime \prime} \mathrm{W}$ ) is a belt of ultramafics approximately $53 \mathrm{~km}$ long and 3-6 km wide 
consisting mainly of serpentinite and peridotite. Most of the belt occurs in Plumas County (Northern California, USA) although parts also stretch into Sierra, Placer, and EI Dorado Counties. The elevations range from 760 to $1920 \mathrm{~m}$, the latter being the peak of Red Hill where both study taxa can be found growing in close sympatry. Red Hill is also one of the highest ultramafic peaks in the Sierra Nevada Mountain Range (Alexander et al., 2007).

The genus Monardella (Lamiaceae) is found throughout western North America and contains over 30 different annual and perennial species representing at least 50 recognized taxa. The center of diversity and distribution for this genus is in California where there are approximately 45 taxa and all 30 species. Outside of California, the genus occurs in Washington, Oregon, Idaho, Nevada, and Baja California (Elvin and Sanders, 2009). It has long been known as a taxonomically difficult genus (Epling, 1925), as it commonly hybridizes and hybrids often outnumber the non-hybrids. In addition, many species have subspecies or varieties (Baldwin et al., 2012).

Monardella stebbinsii (MOST) and M. follettii (MOFO) are both classified as strict serpentine endemics by Safford et al. (2005). They are both small-statured woody perennials in the mint family that exhibit a rhizomatous growth form. The two are easily distinguished morphologically by their leaves, which are glabrous in M. follettii and covered by a dense coat of white hairs in M. stebbinsii (Baldwin et al., 2012). The leaves are lanceolate to elliptic with long internodes in $M$. follettii and narrowly ovate in $M$. stebbinsii. However, one need not use these leaf shape characters to distinguish the 
two species, as the difference in leaf pubescence is quite dramatic. While both are restricted to the same region and the same belt of ultramafics, $M$. follettii has a wider distribution than M. stebbinsii across the belt.

Above-ground ecology - In addition to collecting habitat information as outlined in Chapter One (p. 9), temperature was recorded at all five sites for each Monardella. In order to record diurnal temperatures Ibutton temperature loggers (Maxim Integrated Products, Sunnyvale, California) were deployed at each site in a five $\mathrm{cm}$ piece of PVC pipe and attached with wire or string. They were left at the site from July 26- August 22, 2010. The loggers were set to take a temperature reading every two hours.

Soils and soil-tissue relations - Soil and tissue collection and analysis methods were described in Chapter 1. Data were checked for parametry prior to analysis and differences between species for habitat, soil, and tissue data were analyzed using $t$-tests (Microsoft Excel 2007). PCA was performed on the data in Systat 12 to examine separation based on these characters by species in PCA space. Skewed data were logtransformed prior to running the analysis. In order to look for correlation between ionic content of the soil and that which the plant was taking up in its tissue, linear regression analysis was performed, also using Systat 12.

Seed germination, seedling growth and survival - Seeds were collected from five sites per species during the late summer in 2009. In order to create a pooled sample representing more than a single site for each species, rhizospheric field soil was collected from two sites per species and mixed (by species). Twenty seeds from each 
site (representing ten mothers, two seeds collected per mother) were germinated in thirty $15-\mathrm{cm}$ petri dishes in three different soil treatments - native serpentine soil from each of the two species home sites and a control treatment (potting soil). Both native soil treatments were used in order to see if the species pair would show any signs of local adaptation to their respective soil type. The potting soil served as a control treatment in order to determine if germination and survival would increase in soil more favorable for plant growth.

Prior to germination, three groups of 20 seeds each from the five populations per species were weighed in order to compare average seed weight between species. Groups of 20 seeds were used because it was difficult to get one seed to register weight on the scale due to its miniscule size. Seeds were given a two-week cold treatment in a growth chamber (Conviron, Winnipeg, Manitoba) with a constant temperature of $5^{\circ} \mathrm{C}$ and then the temperature was changed to $15^{\circ} \mathrm{C}$ during the day and $10^{\circ} \mathrm{C}$ at night to start germination (12 hour day/12 hour night).

Germination was recorded weekly for nine weeks at which point germination ceased. Surviving seedlings were then transplanted to 68 two-inch pots in their respective soil types (both species home soil and potting soil). Seedling measurements were taken on size including height, width (of widest leaf), length (of longest leaf), and number of leaves per seedling. 
Breeding systems - Six plants from six populations per species were randomly selected to determine if the species are predominantly selfers or outcrossers. Methods for the bagging experiment were described in Chapter one (p. 12).

Reproductive ecology - Pollination was observed at peak flowering over the summer of 2010. Three sites per species were visited and pollinator observations were done from 1000-1100 $\mathrm{h}$ and 1300-1400 $\mathrm{h}$ (PST) with three separate plants observed each hour. Both species of Monardella spread by underground rhizomes, making it very difficult or impossible to identify an individual plant. In order to make observations feasible, an individual was defined as a $0.5 \mathrm{~m}$ square clump. The number of heads and open non-dried flowers were counted and recorded in each clump. A visitor was defined as any animal that landed on a flower and made contact with the stigma or anthers during the hour sitting. Visitors were collected for identification and observers used consistent codes for all visitors. This was done in order to be able to show the diversity of visitors even if those visitors were unidentified. The Shannon-Weiner Diversity index was used to examine the diversity of pollinators for M. stebbinsii in comparison to $M$. follettii.

For five plants per site at each of the five sites the number of buds, flowers and fruits (depending on phonological state) were counted to determine the average number of reproductive units per plant. Although a single flower is technically one reproductive unit, the Monardella inflorescence is a compact head, and counting the 
individual flowers would have been extremely time consuming. In order to collect data in a timely fashion, I defined a head of buds, flowers or fruits as one reproductive unit.

Results - Above-ground ecology - Results of the above ground ecology data collection showed significant differences between percent slope, percent boulder cover, percent duff cover, percent herbaceous cover, and percent canopy cover (Table 8). $M$. stebbinsii sites were steeper $(p=0.05)$, had lower canopy cover $(p<0.001)$, and were hotter on average (daily) by $4{ }^{\circ} \mathrm{C}(\mathrm{p}<0.001$, Table 8$)$.

Table 8. Habitat variables for the Monardellas.

\begin{tabular}{cccc}
\hline Variable & M. follettii & M. stebbinsii & P Value \\
\hline Slope & $23 \pm 1.6(8-31)$ & $79 \pm 3(65-105)$ & $<0.001$ \\
Aspect & $165.2 \pm 15.9(90-301)$ & $168 \pm 13.2(90-250)$ & 0.47 \\
Percent Rock & $43 \pm 2.3(30-60)$ & $48 \pm 2.8(25-65)$ & 0.22 \\
Percent Boulder & $29 \pm 3.3(15-60)$ & $70 \pm 1.4(60-80)$ & $\mathbf{0 . 0 0 4}$ \\
Percent Duff & $65 \pm 5(20-90)$ & $8.6 \pm 0.7(5-15)$ & $\mathbf{0 . 0 0 5}$ \\
Percent Shrub & $41.6 \pm 5.3(10-85)$ & $17 \pm 2.1(5-30)$ & 0.07 \\
Percent Herb & $37 \pm 3.3(10-60)$ & $7.2 \pm 1.3(1-20)$ & $\mathbf{0 . 0 1}$ \\
Canopy Cover & $35.5 \pm 4(0-72)$ & $19.1 \pm 3.7(0-82)$ & $\mathbf{0 . 0 0 2}$ \\
Light Intensity & $1141.8 \pm 145.5(52-2235)$ & $966.52 \pm 167(56-2225)$ & 0.21 \\
Temperature & $22.5 \pm 1.2(6.4-48.5)$ & $25.5 \pm 0.85(13.1-46.4)$ & $<0.001$ \\
\hline
\end{tabular}

Notes: Values displayed for slope and canopy cover are in percent and aspect is in degrees. Light intensity is measured in $\mu \mathrm{mol} \mathrm{m} \mathrm{m}^{-2}$ and temperature is in ${ }^{\circ} \mathrm{C}$. Values listed are as follows: mean \pm SE (range). For canopy cover and light intensity $n=25$, for temperature $n=336$ and $n=5$ for all other variables. P-values are based on a two sample t-test with significant values listed in bold font.

Both taxa had Pinus jeffreyi Grev. and Balf. (Jeffrey Pine; Pinaceae) and Calocedrus decurrens (Torr.) Florin (Incense Cedar; Cupressaceae) as dominant species at all sites as well as Ceanothus arcuatus McMinn (Arching Ceanothus; Rhamnaceae). 
Additional dominants at M. follettii sites were Pseudotsuga menziesii (Mirb.) Franco (Douglas-Fir; Pinaceae), Pinus lambertiana Douglas (Sugar Pine; Pinaceae), and Ceanothus integerrimus Hook. and Arn. (Deer Brush; Rhamnaceae). Other associated species for the two include Quercus durata Jeps. (Leather Oak; Fagaceae), Quercus chrysolepis Liebm. (Canyon Live Oak; Fagaceae), Epilobium minutum Lindl. (Willow Herb; Onagraceae), Aspidotis densa (Brack.) Lellinger (Indian's Dream; Pteridaceae), Streptanthus tortuosus Kellogg (Mountain Jewelflower; Brassicaceae), Holodiscus microphyllus Rydb. (Rock Spiraea; Rosaceae), Eriogonum ursinum S. Watson (Bear Valley Buckwheat; Polygonaceae), Eriogonum nudum Benth. (Naked Buckwheat; Polygonaceae), Chrysothamnus nauseosus (Pall. Ex Pursh) Britton (Rubber Rabbitbrush; Asteraceae), Eriophyllum lanatum (Pursh) J. Forbes (Woolly Sunflower; Asteraceae), Achillea millefolium L. (Yarrow; Asteraceae), Erigeron petrophilus Greene var. sierrensis G. L. Nesom (Serpentine Rayless Daisy; Asteraceae), Packera eurycephala (Torr. and A. Gray) W. A. Weber and Á. Löve var. lewisrosei (J. T. Howell) J. F. Bain (Cutleaf Ragwort; Asteraceae), Frangula purshiana Cooper subsp. ultramafica Sawyer and S. W. Edwards (Plumas Coffeeberry; Rhamnaceae) and Arabis constancei Rollins (Constance's Rock Cress; Brassicaceae). Additional associates at M. stebbinsii sites include Penstemon deustus Lindl. (Scabland Penstemon; Plantaginaceae) and Sedum albomarginatum R. T. Clausen (Feather River Stonecrop; Crassulaceae). 
Soils and soil-tissue relations - For the soil analysis, organic matter (MOFO>MOST), P (MOST>MOFO), pH (MOST>MOFO), K (MOFO>MOST), Ca (MOFO>MOST), Mg (MOFO>MOST), $\mathrm{Ca} / \mathrm{Mg}$ molar ratio (MOFO>MOST), $\mathrm{S}$ (MOST>MOFO), $\mathrm{Ni}$ (MOFO>MOST), Mn (MOFO>MOST) and cation exchange capacity (MOFO>MOST) were all significantly different between the two taxa (Table 9). For the soil PCA the first principle component explained $29 \%$ of the variance and was influenced by $\mathrm{pH}$, organic matter, $\mathrm{K}, \mathrm{Ni}$, cation exchange capacity, $\mathrm{Mn}$, soil moisture, $\mathrm{Ca} / \mathrm{Mg}$ ratio and $\mathrm{P}$. The second principle component explained $15 \%$ of the variance and was influenced by $\mathrm{Zn}, \mathrm{Fe}, \mathrm{S}, \mathrm{Cu}$, and Mn (Figure 4, Table 10).

Significant differences in the tissue content for the two Monardella's was found for $\mathrm{K}$ (MOFO>MOST), Mg (MOST>MOFO), Al (MOFO>MOST), Fe (MOFO>MOST), Zn (MOFO>MOST) and Ni (MOFO>MOST) (Table 11). The tissue PCA showed separation between the two taxa with the first component explaining $25 \%$ of the variance and being mainly influenced by Fe, Al, Ni, P, K, Zn, Na, and B (Figure 5, Table 12). The second component explained $19 \%$ of the variance and was mainly influenced by $\mathrm{Mn}, \mathrm{Zn}, \mathrm{Ca} / \mathrm{Mg}$ ratio, $\mathrm{B}, \mathrm{Ni}$, and $\mathrm{Cu}$ (Figure 5, Table 12). 
Table 9. Soil analysis for the Monardellas.

\begin{tabular}{cccc}
\hline $\begin{array}{c}\text { Soil } \\
\text { Variable }\end{array}$ & M. follettii & M. stebbinsii & P Value \\
\hline $\mathrm{OM}$ & $7.27 \pm 0.67(3.6-16.3)$ & $3.66 \pm 0.46(1.8-12.8)$ & $<0.001$ \\
$\mathrm{P}$ & $1.86 \pm 0.34(0.6-10.1)$ & $2.77 \pm 0.29(0.7-6.8)$ & 0.03 \\
$\mathrm{pH}$ & $6.62 \pm 0.06(6.1-7.2)$ & $7.28 \pm 0.05(6.8-7.7)$ & $<0.001$ \\
$\mathrm{~K}$ & $87.74 \pm 6.04(39.5-187.8)$ & $48.43 \pm 4.82(16.8-100.3)$ & $<0.001$ \\
$\mathrm{Ca}$ & $598.48 \pm 55.85(239.5-1386)$ & $298.77 \pm 27.58(129.1-699.6)$ & $<0.001$ \\
$\mathrm{Mg}$ & $1273.30 \pm 107.46(411.1-2532)$ & $967.7 \pm 99.37(294-1978)$ & 0.001 \\
$\mathrm{Ca} / \mathrm{Mg}$ & $0.59 \pm 0.08(0.1-1.9)$ & $0.37 \pm 0.04(0.1-0.7)$ & 0.007 \\
$\mathrm{Na}$ & $11.56 \pm 0.48(10-20.3)$ & $12.28 \pm 0.62(10-21.8)$ & 0.17 \\
$\mathrm{CEC}$ & $14.55 \pm 0.85(6.6-22.4)$ & $8.75 \pm 0.74(3.5-18.4)$ & $<0.001$ \\
$\mathrm{~S}$ & $2.06 \pm 0.26(0.7-5.9)$ & $2.78 \pm 0.38(0.3-7.1)$ & 0.07 \\
$\mathrm{Ni}$ & $73.26 \pm 6.27(24.5-141)$ & $24.5 \pm 2.45(9.8-48.9)$ & $<0.001$ \\
$\mathrm{Zn}$ & $1.22 \pm 0.15(0.3-2.6)$ & $2.14 \pm 0.67(0.3-16)$ & 0.09 \\
$\mathrm{Mn}$ & $39.56 \pm 2.93(20-75)$ & $23.64 \pm 1.99(5-46)$ & $<0.001$ \\
$\mathrm{Fe}$ & $26.84 \pm 2.37(9-52)$ & $30.16 \pm 2.64(13-57)$ & 0.19 \\
$\mathrm{Cu}$ & $0.82 \pm 0.08(0.4-2.2)$ & $0.74 \pm 0.09(0.3-2.5)$ & 0.3 \\
$\mathrm{Moisture}$ & $6.06 \pm 0.85(1.1-21.5)$ & $2.32 \pm 0.31(0-6)$ & $<0.001$ \\
& & & \\
\hline
\end{tabular}

Notes: Values displayed for organic matter $(\mathrm{OM})$ are in percent, elemental concentrations are measured in $\mathrm{gg} \mathrm{g}^{-1}$ dry soil (ppm), cation exchange capacity (CEC) was measured in meq $100 \mathrm{~g}^{-1}$, and soil moisture was measured in \% volumetric water content. Values listed are as follows: mean $\pm S E$ (range), $n=25$. P-values are based on a two sample t-test with significant values listed in bold font. 


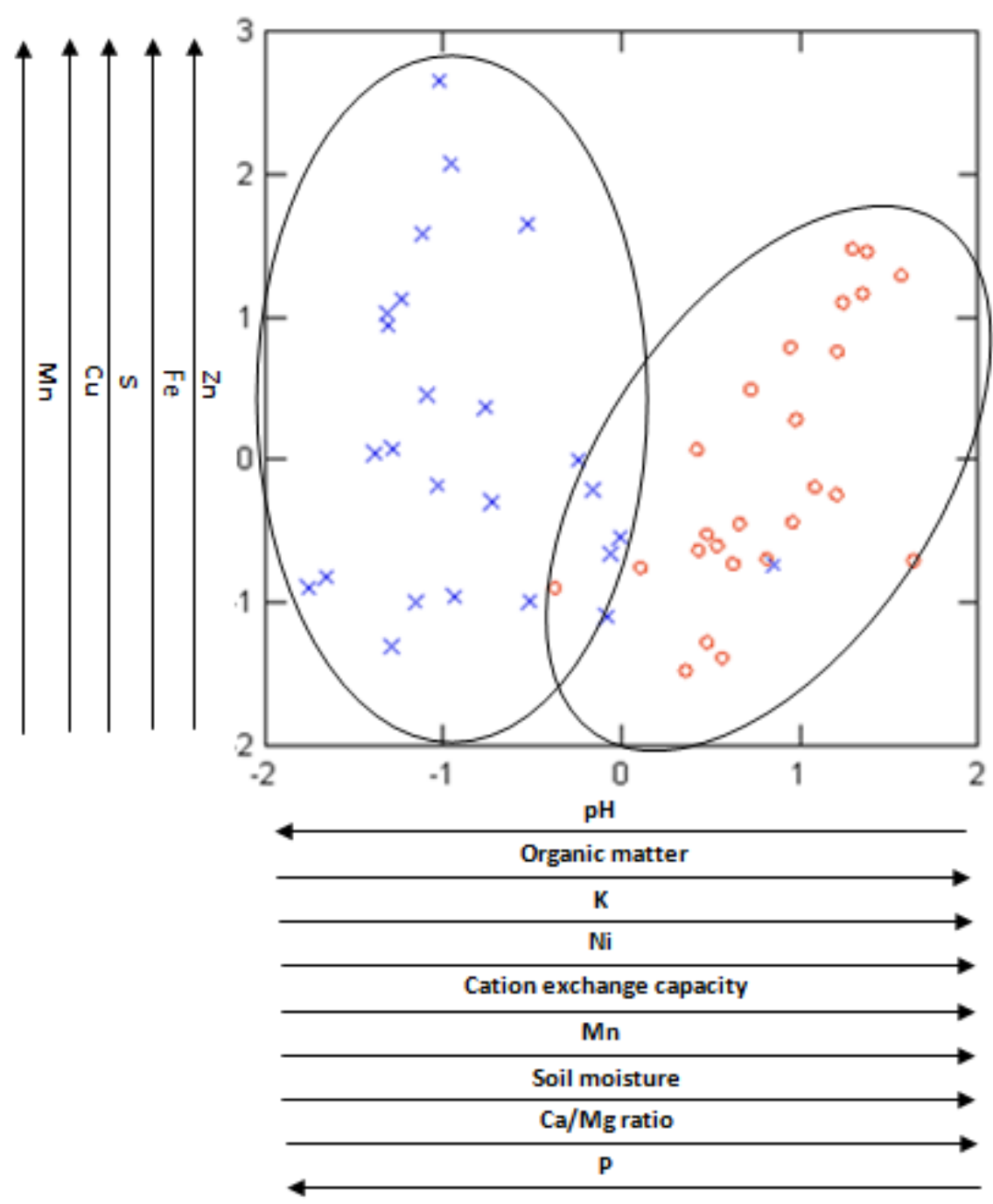

Figure 4. PCA of soil variables for the Monardellas.

Notes: The $x$-axis is PC 1 and the $y$-axis is PC 2. Arrows are in order of the loadings (the closest to the plot being the strongest loading) and their direction (negative or positive). $M$. stebbinsii $=$ $\mathrm{X} ; \mathrm{M}$. follettii $=\mathrm{O}$ 
Table 10. PCA of soil variables for the Monardellas.

\begin{tabular}{|c|c|c|}
\hline & PC 1 & PC 2 \\
\hline Eigenvalues & 4.114 & 2.235 \\
\hline \multirow[t]{2}{*}{$\%$ variance explained } & 29.385 & 15.966 \\
\hline & Loadings & Loadings \\
\hline Soil moisture & 0.534 & -0.065 \\
\hline Organic matter & 0.799 & 0.168 \\
\hline$P$ & -0.452 & 0.232 \\
\hline $\mathrm{pH}$ & -0.858 & -0.194 \\
\hline $\mathrm{K}$ & 0.777 & -0.272 \\
\hline $\mathrm{Ca} / \mathrm{Mg}$ ratio & 0.493 & 0.35 \\
\hline $\mathrm{Na}$ & -0.179 & 0.059 \\
\hline Cation exchange capacity & 0.647 & -0.2 \\
\hline S & -0.27 & 0.489 \\
\hline $\mathrm{Ni}$ & 0.749 & -0.233 \\
\hline $\mathrm{Zn}$ & 0.01 & 0.828 \\
\hline $\mathrm{Mn}$ & 0.554 & 0.413 \\
\hline $\mathrm{Fe}$ & 0.094 & 0.702 \\
\hline $\mathrm{Cu}$ & 0.045 & 0.477 \\
\hline
\end{tabular}

Notes: Notes: Principle components analysis for soil variables for the two Monardella's. Eigenvalues, percent variance explained and component loadings are shown. Significant loadings are listed in bold. 
Table 11. Leaf tissue analysis for the Monardellas.

\begin{tabular}{cccc}
\hline $\begin{array}{c}\text { Tissue } \\
\text { Variable }\end{array}$ & M. follettii & M. stebbinsii & P Value \\
\hline $\mathrm{K}$ & $10517.3 \pm 531.4(6856-16777)$ & $7488.6 \pm 742.1(1758-14869)$ & $<0.001$ \\
$\mathrm{Ca}$ & $4829.8 \pm 379.4(1253-7353)$ & $4644.3 \pm 292.4(2513-7690)$ & 0.29 \\
$\mathrm{Mg}$ & $7577.3 \pm 383.8(4624-11815)$ & $10337.9 \pm 641.2(5145-15731)$ & 0.007 \\
$\mathrm{Ca} / \mathrm{Mg}$ & $0.6 \pm 0.06(0.1-1.3)$ & $0.5 \pm 0.04(0.2-1.1)$ & 0.15 \\
$\mathrm{P}$ & $988.3 \pm 63(611-1768)$ & $880.1 \pm 43.5(583-1365)$ & 0.14 \\
$\mathrm{Al}$ & $56.8 \pm 10.3(12.9-247)$ & $31 \pm 5.1(0.8-94.3)$ & 0.01 \\
$\mathrm{~B}$ & $21.8 \pm 2.9(3-75)$ & $18.9 \pm 0.9(12.7-27.8)$ & 0.17 \\
$\mathrm{Cu}$ & $5.7 \pm 0.6(1.2-11.8)$ & $6 \pm 0.6(3-12.4)$ & 0.34 \\
$\mathrm{Fe}$ & $165.8 \pm 29.9(34.1-750)$ & $72.3 \pm 11(18.6-213)$ & $<0.001$ \\
$\mathrm{Mn}$ & $45.6 \pm 5.5(10.8-126)$ & $39.6 \pm 3.2(11.1-71.6)$ & 0.22 \\
$\mathrm{Zn}$ & $29.7 \pm 1.7(13.6-55)$ & $17.6 \pm 1.3(7.7-32.3)$ & $<0.001$ \\
$\mathrm{Na}$ & $37.9 \pm 2.7(17-75.3)$ & $34.2 \pm 2.8(9.9-65.3)$ & 0.37 \\
$\mathrm{Ni}$ & $102.8 \pm 13(33.9-256)$ & $16.4 \pm 1.5(5.6-37.2)$ & $<0.001$ \\
\hline
\end{tabular}

Notes: Measurement units are $\mathrm{mg} / \mathrm{kg}$ and values listed area as follows: mean $\pm \mathrm{SE}$ (range), $\mathrm{n}=21$ for $M$. follettii and $\mathrm{n}=25$ for $M$. stebbinsii. P-values are based on two sample $t$-tests and significant values are listed in bold font. 


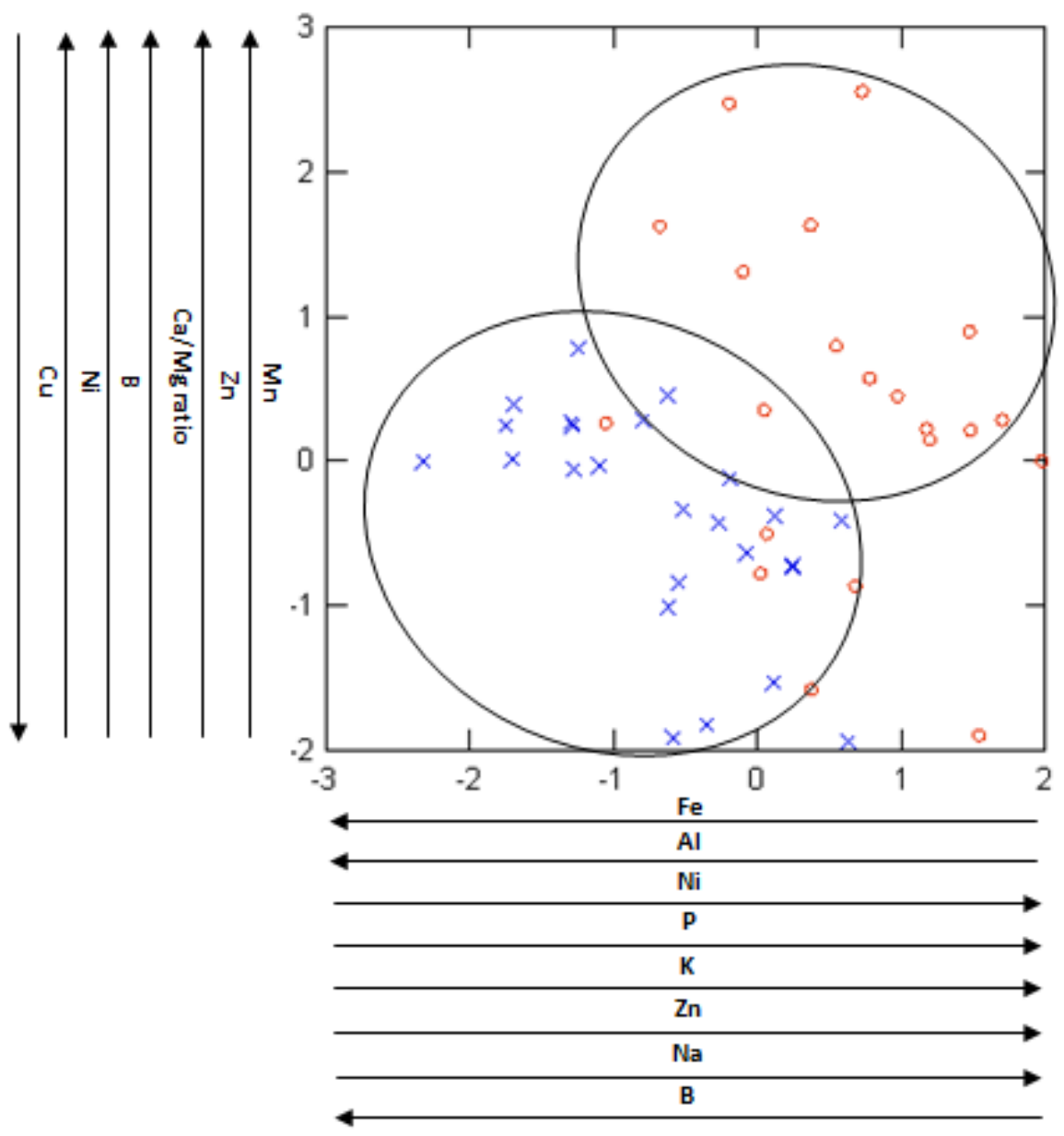

Figure 5. PCA of leaf tissue variables for the Monardellas.

Notes: The $x$-axis is PC 1 and the $y$-axis is PC 2 . Arrows are in order of the loadings (the closest to the plot being the strongest loading) and their direction (negative or positive). $M$. stebbinsii $=$ $\mathrm{X} ; \mathrm{M}$. follettii $=\mathrm{O}$ 
Table 12. PCA of leaf tissue variables for the Monardellas.

\begin{tabular}{|c|c|c|}
\hline & PC 1 & PC 2 \\
\hline Eigenvalues & 2.815 & 2.158 \\
\hline \multirow[t]{2}{*}{$\%$ variance explained } & 25.593 & 19.622 \\
\hline & Loadings & Loadings \\
\hline K & 0.493 & 0.069 \\
\hline $\mathrm{Ca} / \mathrm{Mg}$ ratio & 0.117 & 0.604 \\
\hline$P$ & 0.51 & 0.06 \\
\hline $\mathrm{Al}$ & -0.753 & 0.258 \\
\hline B & -0.426 & 0.482 \\
\hline $\mathrm{Cu}$ & 0.293 & -0.392 \\
\hline $\mathrm{Fe}$ & -0.766 & 0.086 \\
\hline $\mathrm{Mn}$ & -0.19 & 0.806 \\
\hline $\mathrm{Zn}$ & 0.475 & 0.666 \\
\hline $\mathrm{Na}$ & 0.428 & -0.074 \\
\hline $\mathrm{Ni}$ & 0.657 & 0.477 \\
\hline
\end{tabular}

Notes: Notes: Principle components analysis for leaf tissue variables for the two Monardella's. Eigenvalues, percent variance explained and component loadings are shown. Significant loadings are listed in bold.

The elemental content of soil and tissue were significantly correlated for some of the elements in each of the two Monardellas as regression analysis came back significant. For M. stebbinsii, positive correlations were found between soil and tissue content for $\mathrm{K}, \mathrm{Ni}$ and $\mathrm{Zn}$ (Figure 6). For $\mathrm{M}$. follettii positive correlations were found between soil and tissue content of $\mathrm{Ca} / \mathrm{Mg}$ ratio, $\mathrm{K}, \mathrm{Ni}$, and $\mathrm{Mn}$ while a negative correlation was found for Cu content (Figure 7). 

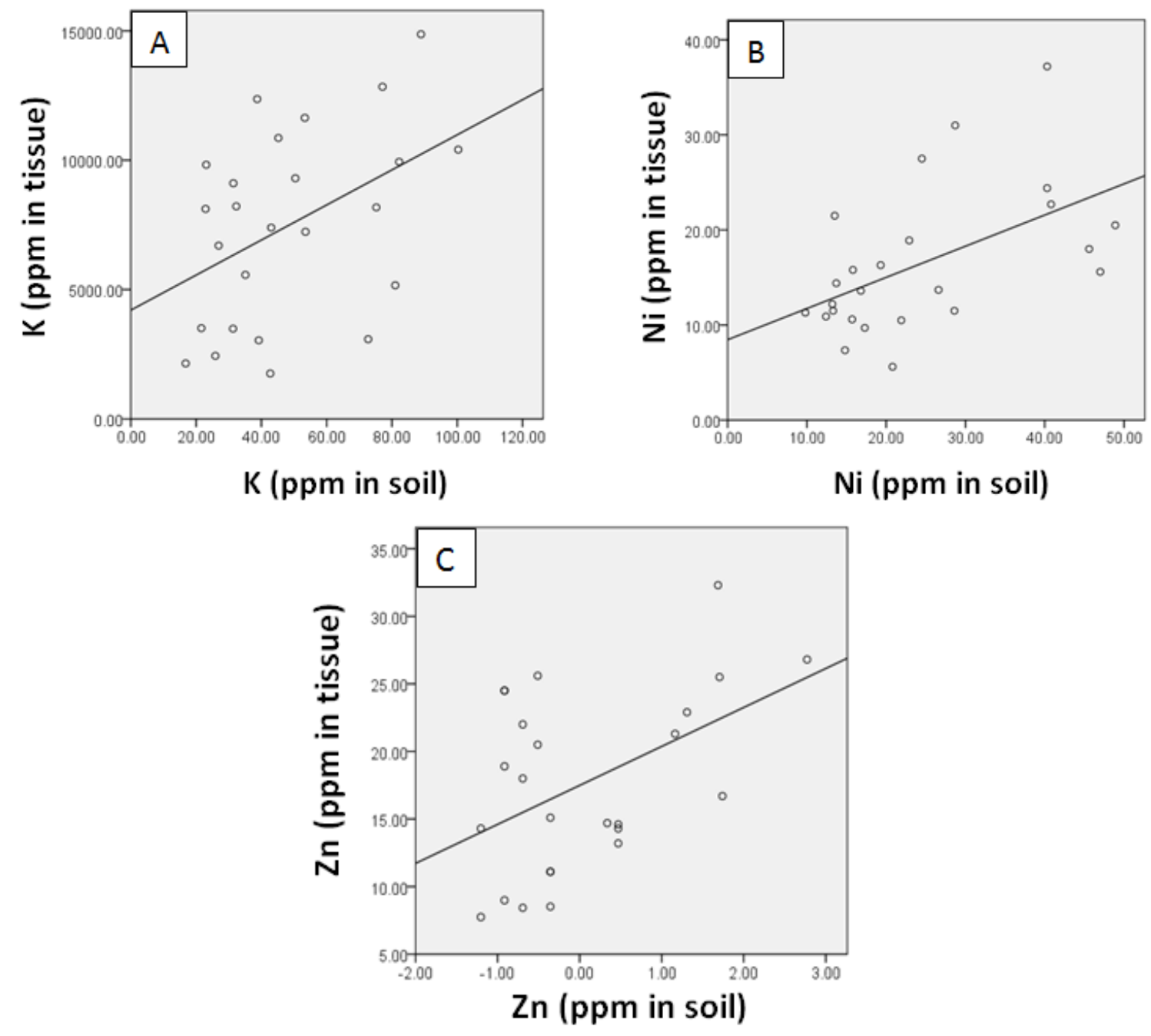

Figure 6. Linear regression - Monardella stebbinsii.

Notes: Linear regression between soil and plant tissue concentrations for Monardella stebbinsii. A) $\mathrm{K}: \mathrm{r}^{2}=0.194 ; \mathrm{P}=0.027$; $\mathrm{f}$-ratio $=5.542$. B) Ni: $r^{2}=0.282 ; \mathrm{P}=0.006$; f-ratio $=9.020$. C) $\mathrm{Zn}: \mathrm{r}^{2}=$ $0.222 ; \mathrm{P}=0.017$; f-ratio $=6.581$. 

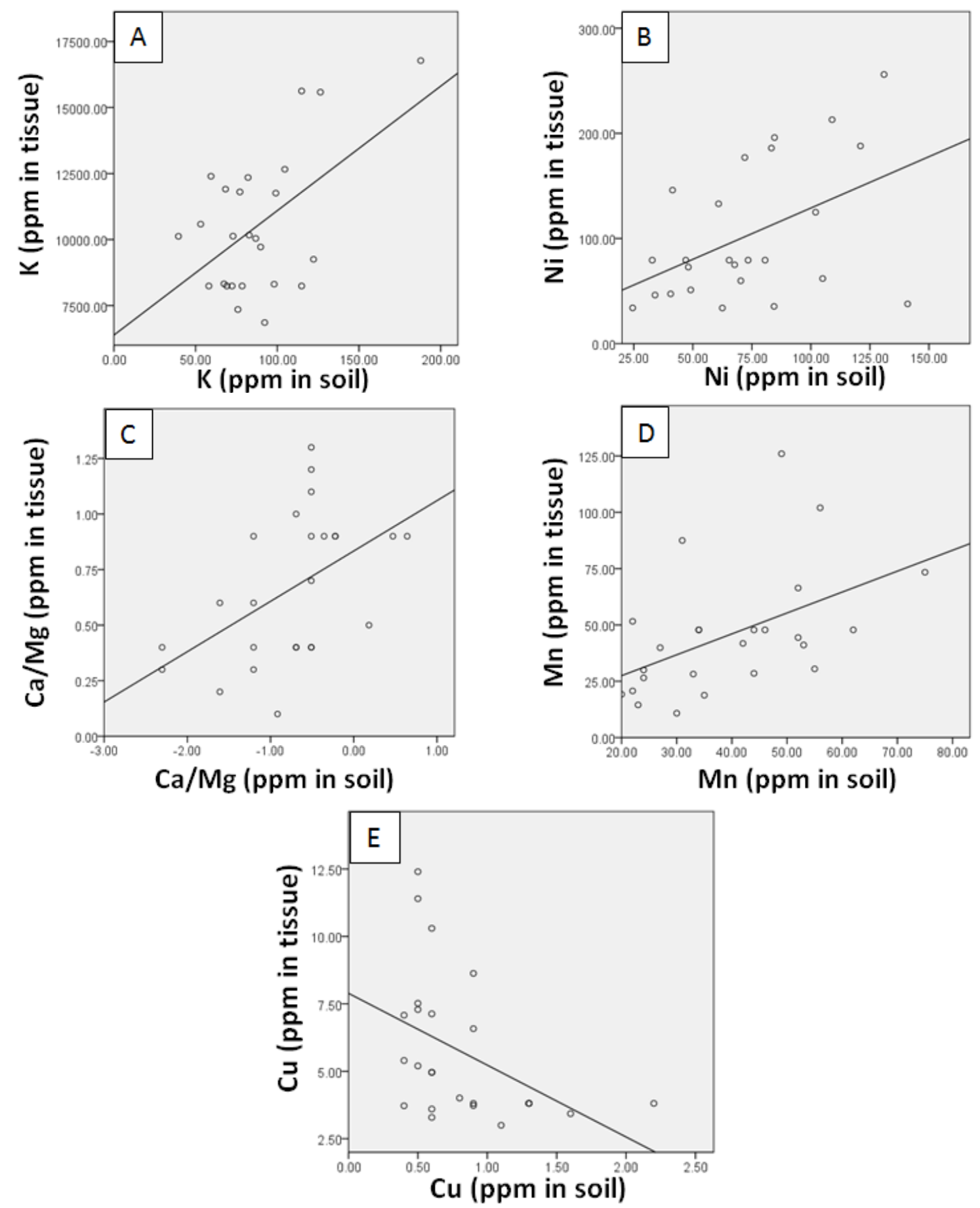

Figure 7. Linear regression - Monardella follettii.

Notes: Linear regression between soil and plant tissue concentrations for Monardella follettii $\mathrm{A}$ ) $\mathrm{K}: \mathrm{r}^{2}=0.287 ; \mathrm{P}=0.006 ; \mathrm{f}$-ratio $=9.27$. B) Ni: $\mathrm{r}^{2}=0.22 ; \mathrm{P}=0.018 ; \mathrm{f}$-ratio $=6.48$.

C) $\mathrm{Ca} / \mathrm{Mg}: \mathrm{r}^{2}=0.245 ; \mathrm{P}=0.012 ; \mathrm{f}$-ratio $=7.45$. D) $\mathrm{Mn}: \mathrm{r}^{2}=0.241 ; \mathrm{P}=0.013 ; \mathrm{f}$-ratio $=7.30$.

E) $\mathrm{Cu}: r^{2}=0.193 ; P=0.028 ; f$-ratio $=5.509$ 
Seed germination, seedling growth and survival - M. stebbinsii and M. follettii had average germination rates of $74 \%$ (SE \pm 0.04 , range $40-95)$ and $62 \%$ (SE \pm 0.03 , range 30-80), respectively ( $p=0.02$ ). In soil from $M$. follettii sites, $M$. stebbinsii sites and standard potting soil, M. stebbinsii had average germination rates of 74\% (SE \pm 0.08 , range $40-85), 77 \%$ (SE \pm 0.05 , range $60-85)$ and $72 \%$ (SE \pm 0.1 , range $45-95)$, respectively, and in the same three soil types $M$. follettii had average germination rates of $64 \%$

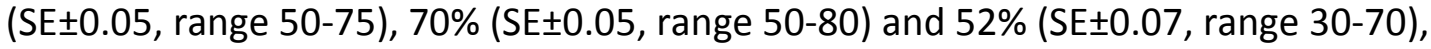
respectively (Table 13). The average seed weight (Table 14) per individual seed was 0.67

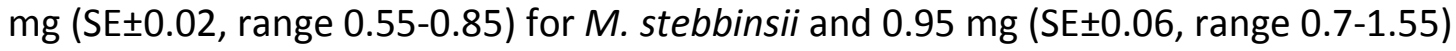
for M. follettii $(p<0.001)$.

M. follettii seedlings had $100 \%$ survival when planted in M. follettii soil, $77 \%$ survival when planted in potting soil and $0 \%$ survival when planted in $M$. stebbinsii soil (Table 15). M. stebbinsii had 0\% survival when planted in M. stebbinsii soil, $44 \%$ survival when planted in potting soil and $76 \%$ survival when planted in $M$. follettii soil (Table 15). Size measurements on both species in all three soil types showed that seedlings grown in potting soil and $M$. follettii soil were the largest and most robust while those grown M. stebbinsii soil were much smaller (Table 16). 
Table 13. Germination rates.

\begin{tabular}{|c|c|c|c|}
\hline & $\begin{array}{c}\text { MOFO } \\
\text { SOIL }\end{array}$ & $\begin{array}{l}\text { MOST } \\
\text { SOIL }\end{array}$ & $\begin{array}{l}\text { POTTING } \\
\text { SOIL }\end{array}$ \\
\hline MOFO 26N26 & 55 & 80 & 40 \\
\hline MOFO Bean Hill & 70 & 70 & 60 \\
\hline MOFO Virgilia & 70 & 75 & 60 \\
\hline MOFO Silver Lake & 75 & 50 & 30 \\
\hline MOFO Red Hill & 50 & 75 & 70 \\
\hline MOST Queen Lily & 40 & 80 & 45 \\
\hline MOST 003 & 85 & 75 & 95 \\
\hline MOST Red Hill & 80 & 85 & 55 \\
\hline MOST 005A & 80 & 60 & 70 \\
\hline MOST 001A & 85 & 85 & 95 \\
\hline
\end{tabular}

Notes: Percent germination for all populations of both Monardellas. Numbers reported are in percent and represent groups of 20 seeds. The respective soil types that seeds were germinated in are listed across the top. 
Table 14. Seed weight.

\begin{tabular}{cc|cc}
\hline \multicolumn{1}{c}{ Site } & \multicolumn{1}{c}{ Weight (mg) } & Site & Weight (mg) \\
\hline \multirow{2}{*}{ MOST Queen Lily } & 0.8 & MOFO 26N26 & 0.75 \\
& 0.65 & & 0.75 \\
MOST 003 & 0.65 & & 1 \\
& 0.65 & MOFO Bean Hill & 1 \\
MOST Red Hill & 0.6 & & 0.9 \\
& 0.65 & & 1 \\
MOST 005A & 0.7 & MOFO Virgilia & 0.75 \\
& 0.7 & & 0.95 \\
MOST 001A & 0.65 & & 1.55 \\
& 0.55 & MOFO Silver Lake & 1.1 \\
& 0.6 & & 0.7 \\
Average & 0.55 & & 0.7 \\
& 0.85 & MOFO Red Hill & 0.9 \\
& 0.75 & & 1.1 \\
& 0.8 & & 1.1 \\
& 0.67 & Average & 0.95 \\
\hline
\end{tabular}

Notes: Seed weight for all populations of both Monardellas. Seeds were weighed in groups of 20. The average for one seed was calculated and is reported below. Three separate groups were weighed for each population. The weight was compared between the two species and was significantly higher in $M$. follettii $(p<0.001)$.

Table 15. Seedling survivorship.

\begin{tabular}{|ccccccc|}
\hline Soil source & MOFO & MOFO & MOST & MOST & Potting & Potting \\
Species & MOFO & MOST & MOFO & MOST & MOFO & MOST \\
\hline Sample size (n) & 7 & 21 & 1 & 21 & 9 & 9 \\
Survival rate & $100 \%$ & $76 \%$ & $0 \%$ & $0 \%$ & $77 \%$ & $44 \%$ \\
\hline
\end{tabular}

Notes: Survivorship of seedlings in soil from $M$. follettii sites, M. stebbinsii sites and in standard potting soil is shown below. The first row lists the source of the soil, the second row lists which species the seed came from, the third row lists the number of seedlings that were transplanted and the bottom row lists the percent of those seedlings that survived. 
Table 16. Size measurements for the Monardellas.

\begin{tabular}{ccccccc}
\hline So & Sp & $\mathbf{n}$ & Height & Width & Length & Leaf \# \\
\hline F & F & 7 & $61.8 \pm 14.5(14-110)$ & $3.7 \pm 0.6(1.5-6)$ & $5.2 \pm 0.7(2.5-7.5)$ & $11.5 \pm 1.0(8-14)$ \\
F & S & 20 & $46.6 \pm 3.5(20-74)$ & $3.1 \pm 0.3(0.5-5.1)$ & $3.7 \pm 0.3(1-6)$ & $9.5 \pm 0.5(4-15)$ \\
S & F & 1 & 22 & 6 & 2 & 5 \\
S & S & 20 & $52.5 \pm 3.6(27-87)$ & $2.8 \pm 0.2(0.5-5)$ & $3.4 \pm 0.2(0.9-5.1)$ & $10.5 \pm 0.7(6-16)$ \\
P & S & 8 & $18 \pm 2.6(9-30)$ & $2.8 \pm 0.4(1-4.5)$ & $3.5 \pm 0.5(1.3-5)$ & $5.1 \pm 1.0(2-10)$ \\
P & F & 9 & $28.5 \pm 4.3(9-45)$ & $3.9 \pm 0.3(2.8-5.5)$ & $4.3 \pm 0.3(3.3-6.2)$ & $8.6 \pm 2.0(4-22)$ \\
\hline So & Sp & n & Height & Width & Length & Leaf \# \\
\hline F & F & 7 & $77.1 \pm 14.4(25-125)$ & $4.8 \pm 0.4(2.8-6.2)$ & $6.5 \pm 0.8(3.1-10)$ & $21.6 \pm 3.1(11-32)$ \\
F & S & 16 & $63.4 \pm 7.3(10-135)$ & $4.2 \pm 0.4(1.2-6.6)$ & $5.8 \pm 0.6(1.4-1.4)$ & $17.1 \pm 1.5(6-29)$ \\
S & $F$ & 0 & $n / a$ & $n / a$ & $n / a$ & $n / a$ \\
S & S & 0 & $n / a$ & $n / a$ & $n / a$ & $n / a$ \\
P & S & 4 & $73.7 \pm 15.1(30-99)$ & $8.4 \pm 1.8(3.8-11.9)$ & $13.1 \pm 3.8(4.5-20.1)$ & $34.5 \pm 6.4(21-52)$ \\
P & F & 7 & $50 \pm 7.3(20-75)$ & $6.5 \pm 0.8(3.4-9.6)$ & $8.8 \pm 1.2(4.3-12.3)$ & $30.4 \pm 3.5(12-42)$ \\
\hline
\end{tabular}

Notes: Results of size measurements for the two Monardellas. The first column is the soil source (So) and the second column is the species (Sp). In the first two columns, $\mathrm{F}=M$. follettii, $\mathrm{S}$ $=M$. stebbinsii, and $\mathrm{P}=$ potting soil. All measurements are taken in $\mathrm{mm}$ and values reported are as follows: mean \pm SE (range) with the exception of the $M$. follettii grown in $M$. stebbinsii soil where the sample size was only one individual. The top set of seedlings were measured on October 28, 2010 and the bottom set on February 1, 2011.

Breeding sytems - Results of the pollen exclosure bag experiment showed that both species are primarily outcrossers, with both taxa setting a significantly greater amount of seed in unbagged vs. bagged flower heads (Figure 8). Results of the two sample t-test comparing bagged and unbagged heads for $M$. follettii showed $p<0.01$ and for $M$. stebbinsii $p=0.01$. When comparing seed set across species in unbagged flower heads, $M$. follettii had a rate of $77 \%$ seed set while $M$. stebbinsii had a rate of $45 \%$ seed set $\quad(p=0.01)$. Seed set across species in bagged flower heads was not significantly different $(p=0.22)$. 


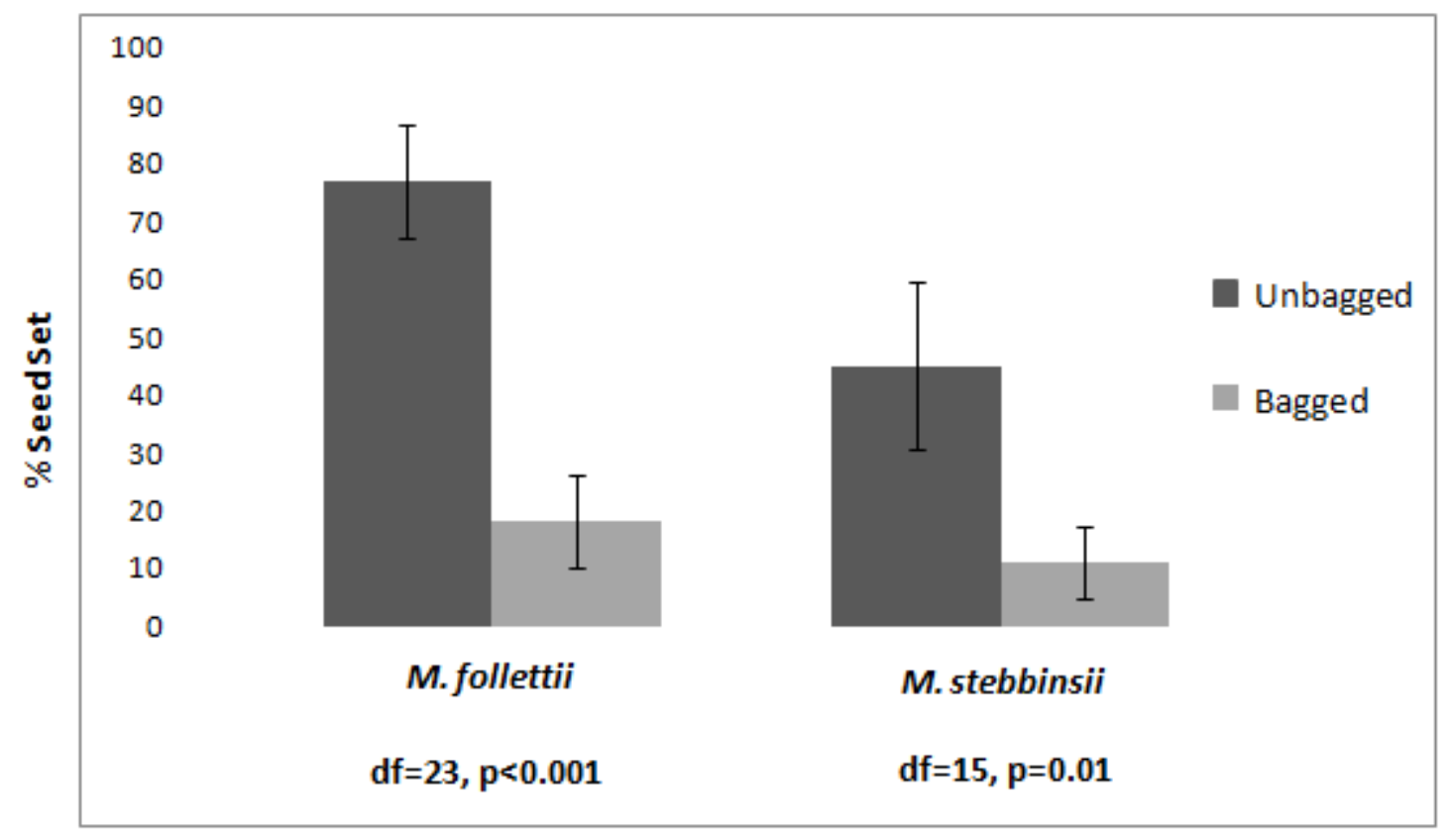

Figure 8. Percent seed set.

Notes: Mean percent seed set for bagged and unbagged specimens of the two Monardellas. Sample size was 24 plants for $M$. follettii and 22 plants for $M$. stebbinsii. Error bars indicate standard error.

Reproductive ecology - Over the course of the three days of observations $M$. stebbinsii had a total of 498 visitors (Figure 9) and $M$. follettii had a total of 393 (Figure 10). Shannon-Weiner diversity indices for M. stebbinsii and M. follettii were 4.33 and 16.29 , respectively. $M$. stebbinsii had a total of nine different morphospecies as visitors and M. follettii had a total of 25. Included in this is a category for "unknown" morphospecies ( $14 \%$ of visits for $M$. follettii and $7 \%$ of visits for $M$. stebbinsii), which could include some of the known insects listed on the graph since I was not able to identify the unknowns (Table 17). Seventy-five percent of visits to $M$. stebbinsii flowers were from three small native bees in the families Apidae, Halictidae and Colletidae (Order: Hymenoptera). Twenty-eight percent of insect visitors were shared between 
the two taxa. There was an average of 6 (SE \pm 1.6 , range $0-28$ ) reproductive units per plant for M. stebbinsii and 44 (SE \pm 21.7 , range $0-530)$ for M. follettii $(p=0.04)$.

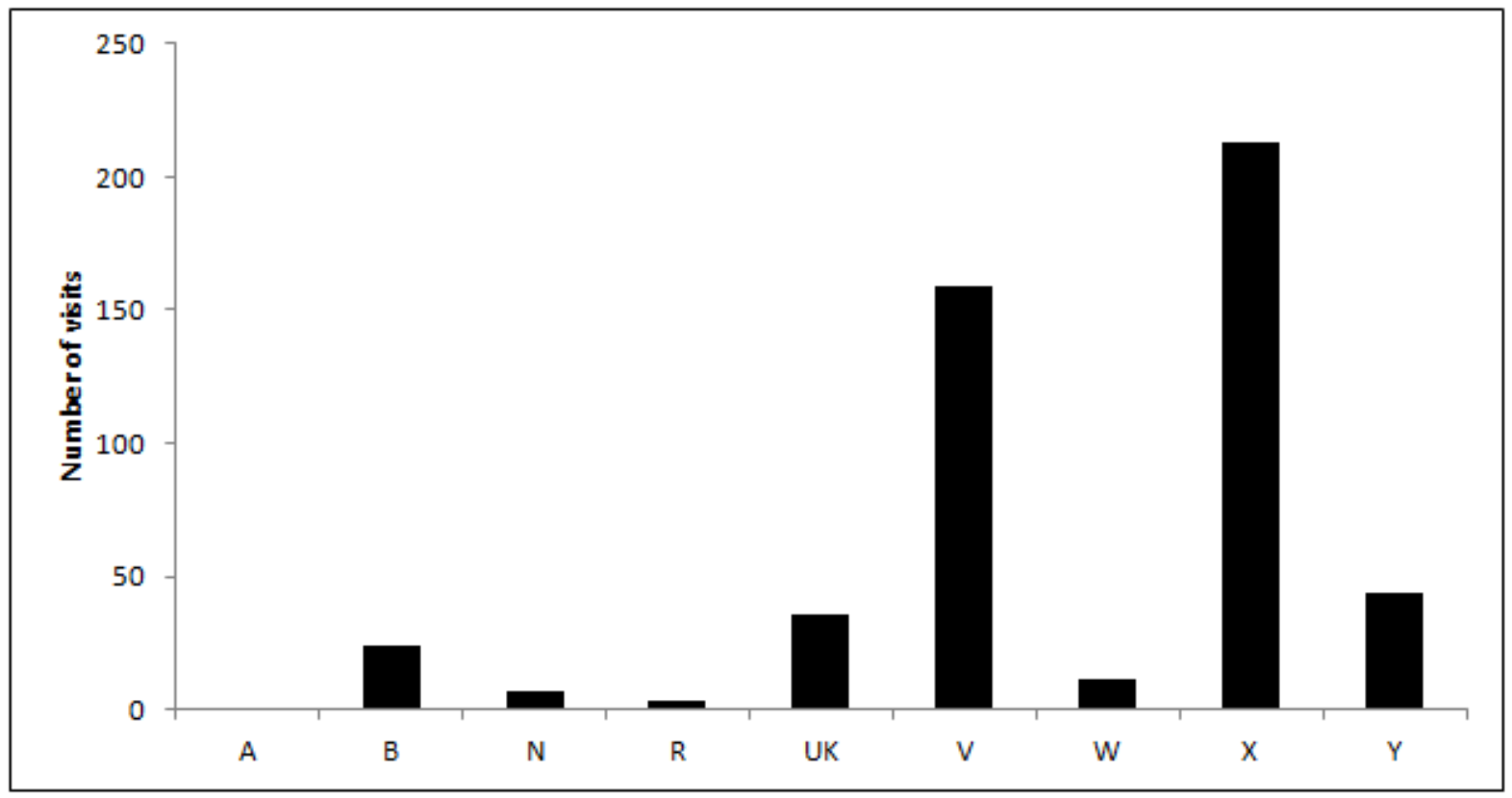

Figure 9. Pollinators for Monardella stebbinsii.

Notes: Each bar represents a different insect, UK stands for unknown pollinator, $n=498$.

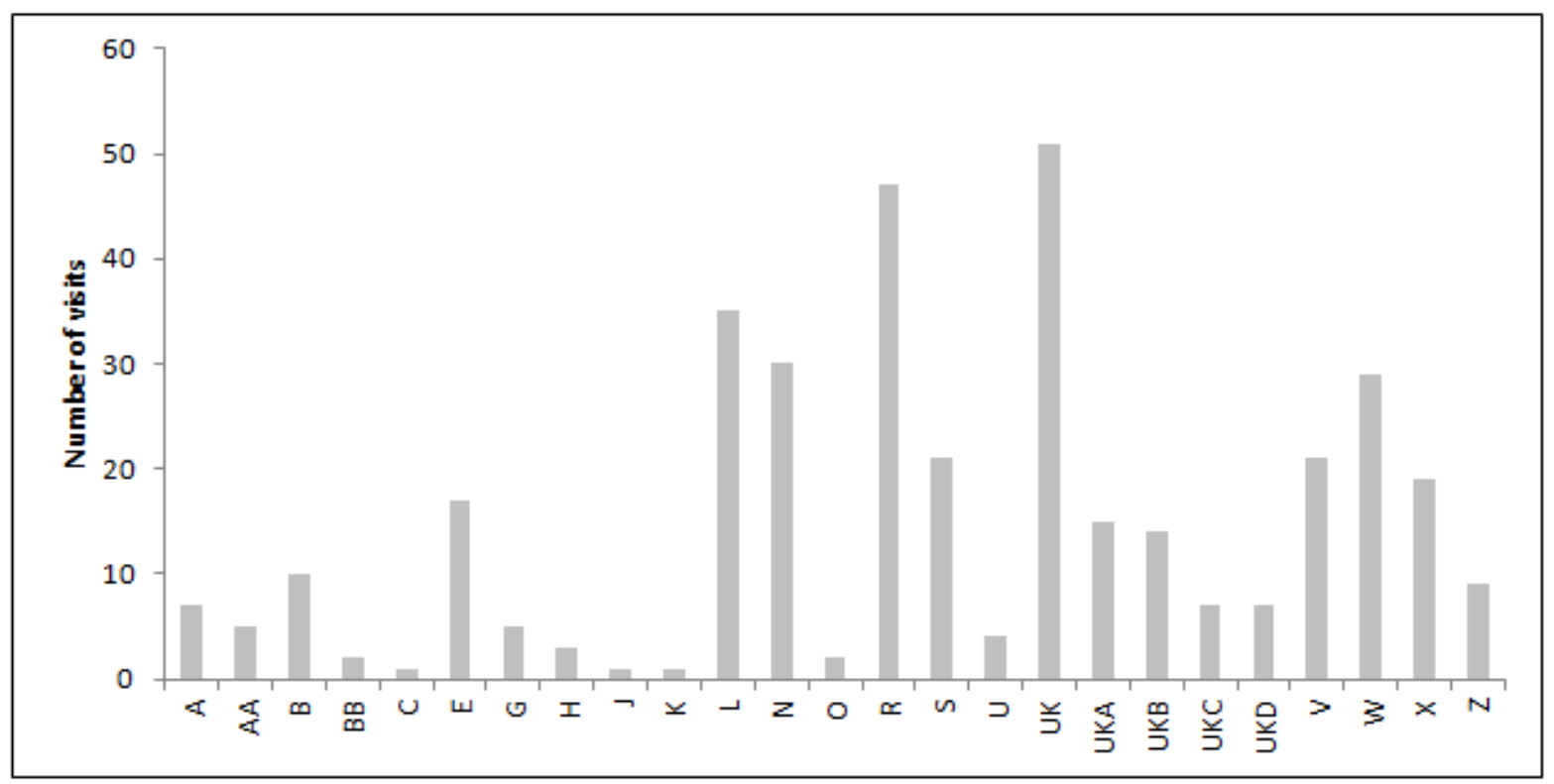

Figure 10. Pollinators for Monardella follettii.

Notes: Each bar represents a different insect, UK stands for unknown pollinator, $n=498$. 
Table 17. Pollinators.

\begin{tabular}{cccc}
\hline CODE & Order: Family: Genus (specific epithet) & MOFO \% & MOST \% \\
\hline A & Lepidoptera: Hesperiidae & 2 & $<1$ \\
AA & Lepidoptera: Nymphalidae & 1 & 0 \\
B & Hymenoptera: Megachilidae & 3 & 1 \\
BB & Coleoptera: Chrysomelidae & $<1$ & 0 \\
C & Diptera: Bombyliidae & $<1$ & 0 \\
E & Diptera: Bombyliidae & 5 & 0 \\
G & Diptera: Bombyliidae & 1 & 0 \\
H & Coleoptera & $<1$ & 0 \\
J & Hymenoptera & $<1$ & 0 \\
K & Diptera: Bombyliidae & $<1$ & 0 \\
L & Hymenoptera: Apidae: Bombus & 10 & 0 \\
N & Hymenoptera: Apidae: Apis (mellifera) & 8 & 1 \\
O & Hymenoptera: Megachilidae: Osmia & $<1$ & 0 \\
R & Hymenoptera: Apidae: Bombus & 13 & 1 \\
S & Hymenoptera: Megachilidae: Osmia & 6 & 0 \\
U & Diptera (small and reddish) & 1 & 0 \\
V & Hymenoptera: Apidae: Ceratina & 0 & 32 \\
W & Hymenoptera: Apidae & 8 & 2 \\
X & Hymenoptera: Halictidae: Lasioglossum and Hymenoptera: Colletidae & 5 & 43 \\
Y & Diptera (<1mm in length) & 0 & 9 \\
Z & Hymenoptera: Apidae: Bombus & 2 & 0 \\
UK & UNKNOWN & 14 & 7 \\
UKA & "small yellow hymenoptera" & 4 & 0 \\
UKB & "small black fly" & 4 & 0 \\
UKC & "brown fly with red/yellow stripes and clear wings" & 2 & 0 \\
UKD & "black and white striped hymenoptera" & 2 & 0 \\
\hline
\end{tabular}

Notes: Total number of pollinators observed on the two Monardellas during peak flowering over the summer of 2010. The first column lists the code shown in Figures 9 and 10, the second column contains the ID for the specimens if known and the last two columns list the percent that visitor represents out of the total number of visits for $M$. follettii and $M$. stebbinsii, respectively. Pollinators that were shared between species are listed in bold. The bottom five rows are unknown pollinators without specimens.

Discussion - Above-ground ecology - When first visiting populations of the two Monardellas it is clear that they occupy very distinct habitats. The most drastic and noticeable difference on first encounter is the steepness of their slopes. In a recent Conservation Assessment on M. stebbinsii prepared for the USFS (Coppoletta and 
Woolhouse, 2010), management recommendations for this taxon were to minimize monitoring as much as possible. Due to the extreme steepness of the slopes, it is very difficult to monitor in a consistent manner and visiting the sites is potentially damaging to the plants through trampling and erosion, as it can be extremely difficult to find footing. Overall, M. stebbinsii sites were much harsher than those of $M$. follettii, being steeper, hotter, and having less canopy cover, thus providing less duff. Although light intensity measurements averaged out to be greater at $M$. follettii sites with the reflection of the large bare serpentine rocks, it felt more intense at $M$. stebbinsii sites. It is possible that this measurement was influenced by different lighting at different times of day, as it was not taken in a consistent manner.

Soils and soil-tissue relations - The results from the soil and tissue analysis demonstrate significant differences in the elemental content of the soil for the two Monardellas, which is most likely leading to the differences seen in ion accumulation for the two. While it is possible that these two taxa have different ion uptake physiologies based on soil ionic content, the differences seen in ion accumulation may be genetically fixed. Further examination is needed in a common garden setting with equal amounts of elements made available to each species in order to determine the nature of the physiological differences.

Much work has been done on the Lasthenia californica complex where it has been shown that edaphic differences within the same serpentine outcrop have led to the partitioning of different races of the same species (Rajakaruna and Bohm, 1999; Yost 
et al., 2012). The soil analysis results for the two Monardellas are also pointing to cryptic heterogeneity across the serpentine landscape that is providing unique niche conditions that these species are keying in on. In a study done in Eastern Australia, Batianoff and Singh (2001) found that serpentine outcrops with higher Ni content in the soil supported a greater number of endemic species when compared to sites with lower soil Ni content. M. follettii grows on sites with greater $\mathrm{Ni}$ content in the soil and is also taking up greater amounts of $\mathrm{Ni}$ in its tissue than $\mathrm{M}$. stebbinsii. Further studies would be useful to shed light on the relationship between $M$. follettii, its associated species, and the high amounts of $\mathrm{Ni}$ found in the soil.

In another study looking at the ecology of Polybotrya ferns across what appeared to be a homogeneous environment in the Amazon, the researchers found that even though the distributions of the ferns overlapped, they each occupied unique niches defined by soil texture, soil cation content and inundation level of the soil (Tuomisto, 2006). When designing conservation and management plans, it is critical to pay attention to these types of cryptic differences that may be found in the edaphic environment and would otherwise go unnoticed. While both taxa are endemic to an ultramafic substrate, there are clearly some cryptic differences across their range contributing to their distribution.

Seed germination, seedling growth and survival - While M. follettii appeared to be more reproductively fit than $M$. stebbinsii, due to greater seed set, more reproductive units and greater seed mass, $M$. stebbinsii had greater germination rates. 
This points to more of a quality over quantity approach in $M$. stebbinsii, the rarer of the two taxa. It is possible that due to the harsh and extreme conditions found at $M$. stebbinsii sites, it would be very difficult if not impossible for a small seedling to survive, and therefore, M. stebbinsii would be making a greater number of high quality seeds. This hypothesis is further supported by the fact that no seedling of either species survived when transplanted into soil from $M$. stebbinsii home sites in a common garden setting. M. follettii sites are more nutrient rich and have higher soil moisture holding capacity than those of $M$. stebbinsii. It is believed that the moisture level in the soil was the main contributing factor to seedling survival in the greenhouse experiment. The pots containing $M$. follettii soil were visually moist whereas pots containing $M$. stebbinsii soil were completely dry. It appears that $M$. stebbinsii has developed a strategy to create a greater amount of seedlings in the hopes that this would mean more survival of a greater number of individuals.

These results are mostly inconsistent with a study done by Carlsen et al. (2002) on reproductive biology of an extremely rare California annual, Amsinckia grandiflora, in comparison to a common congener, A. tessellata. In their study, seed set was greater in the more common of two taxa but the number of flowers per plant and seed mass were greater in the rare taxon which is contrary to what was found in my study. Consistent results were not found in their germination trials and there was a lot of variation in the results (Carlsen et al., 2002). 
Breeding systems - Both Monardellas are primarily outcrossers. This result is consistent with a study done by Espeland and Emam (2011) that looked at trends in 101 rare species through a literature search and found habitat specialists with small geographic ranges were more likely to have an outcrossed breeding system. Rare plants are known to be associated with high degrees of self-incompatibility which does not lead to large populations but can lead to stable population sizes for rare species (Kunin and Gaston, 1993). Espeland and Emam (2011), point out that high rates of outcrossing help to protect habitat specialists with small geographic ranges from genetic drift, thereby maintaining as much genetic diversity as possible (Ellstrand and Elam, 1993).

Being medium sized shrubs with many flowering stems, it makes sense that these Monardellas will need to be able to self and not be complete and obligate outcrossers. Most insects go from flower to flower on the same plant before moving on to another one. Spreading by rhizomes, there can be very large clumps of the same individual making it possible for an insect to spend its entire time at any given population, only visiting one plant. In fact, it is possible that any given population could be composed of only one plant, although the size and extent of individuals has not yet been examined. Considering seed set in bagged flower heads did not differ between species while unbagged seed set differed significantly, with higher seed set in M. follettii than in M. stebbinsii, pointing to more successful pollination for this taxon.

Reproductive ecology - Pollinators play a critical role in the abundance and persistence of approximately $67 \%$ of flowering plants worldwide (Kearns and Inouye, 
1997). Monardella stebbinsii had a greater total number of insect visitors overall than did M. follettii (498 vs. 393), yet M. follettii had a greater diversity of insect visitors (25 vs. 9 different morphospecies). The pollination system for $M$. stebbinsii appeared to be more specialized, as $75 \%$ of the visitors were from three small (and similar looking to the untrained eye) bees in the familes Apidae, Halictidae, and Colletidae. The behavior of the insects was different depending on which plant species was being visited. The small bees visiting $M$. stebbinsii plants tended to dive into the base of the corolla, sometimes missing the anthers and stigmas completely, while the larger bodied insects that were more common at $M$. follettii plants would crawl across the top of the flower heads definitely making contact with the reproductive structures.

Adaptation to new habitats has been known to bring about shifts in flowering times (Bomblies, 2010). Typically, serpentine populations flower earlier than populations of the same species found on non-serpentine soils, most likely as a means for drought avoidance (Wright et al., 2006), the case for the two Monardellas seems to be slightly different. M. stebbinsii, which is found at the harsher, drier sites, is in full flower in late July/early August while M. follettii is in full flower in June. The difference in flowering times for the two Monardellas could have led to separation as distinct species or be keeping their separate gene pools intact. Although possible hybrids between the two were seen at the top of Red Hill (Lat $40^{\circ} 2^{\prime} 17^{\prime \prime} \mathrm{N}$, Lon $121^{\circ} 11^{\prime} 22^{\prime \prime} \mathrm{W}$ ), this is the only area where the two grow in close sympatry and where cross pollination would be likely during the overlap in flowering times. 
The differences in flowering times could also lead to differences in pollinators between the two species. M. follettii is in flower earlier in the summer when most of the surrounding flowering plants are also in bloom helping to attract pollinators to the general area by putting on impressive floral displays. M. stebbinsii is in full flower very late in the season and almost no other plants are flowering in association when it is trying to attract pollinators. While only $28 \%$ of pollinators were shared between the two taxa, it is possible that this is happening due to which pollinators are around at the time of flowering and not necessarily occurring based on preferential choice by the pollinators.

Although the flowers of the two taxa are almost morphologically identical, it is important to pay attention to differences in pollinators because there may be unseen differences in the flowers taking place that affect pollinator preferences and may lead to reproductive isolation. An example is given with two species of Pedicularis that grow sympatrically. They have the same flower color and structure, but have different lengths for the beak of the corolla, which affects pollen delivery onto the pollinator. It was discovered that these plants were pollinated by the same species of Bombus, but, the visitor gets pollen on different parts of its body depending on which species it visits, thereby preventing cross pollination (Sprague, 1962). Pollinators represent one of the many niche components for most flowering plants and also play a key role in their reproductive fitness (Waser and Ollerton, 2006). 


\section{CHAPTER THREE INTRASPECIFIC VARIATION IN A RARE BODENVAG}

Introduction - Ecotypic differentiation occurs when a set of genetically distinct populations of a particular species are adapted to an identifiable habitat or set of environmental conditions (Gurevitch et al., 2002). Some ecotypes have been shown to be just as well adapted as reproductively isolated serpentine endemics (Alexander et al., 2007). While ecotypes of a species can be locally adapted, the term local adaptation is in reference to a single population that shows increased fitness when grown at its home site. Both ecotypic differentiation and local adaptation are a result of natural selection that occurs within a heterogeneous environment (Wright and Stanton, 2007; Wright, 2007).

There is a great deal of variation in morphology, physiology and reproductive biology exhibited by species in response to environmental heterogeneity. Any given species cannot be considered out of the context of its environment (Bradshaw, 1965). In addition to ecotypic differentiation and local adaptation, species that vary on a site to site basis may also be showing a plastic response. While it is quite likely that many species found across edaphic gradients may be differentiated into genetically distinct ecotypes (Kruckeberg, 1984) and not merely exhibiting plasticity, this is simply heresay without experimentation (Wright et al., 2006; Wright and Stanton, 2011).

From a plants perspective, the amount of obstacles found on physically and chemically harsh serpentine sites can be extremely overbearing. The patchy distribution 
of serpentine soils often allows for close proximity to non-serpentine populations thus perpetuating gene flow between edaphically distinct sites. With all these obstacles in place, adaptation to serpentine has arisen on numerous occasions (Rajakaruna, 2004; Anacker et al., 2010).

Lewisia cantelovii (hereafter referred to as Lewisia or LECA) is what is known as a "bodenvag" (i.e., soil wanderer) because its populations are found growing both on and off serpentine (Kruckeberg, 1984). During field surveys over the summer of 2009, I noticed that there was a distinct serpentinomorphism in the plants found at serpentine sites. My objective for this study was to determine if these populations of Lewisia have formed edaphic ecotypes, or if they are merely exhibiting phenotypic plasticity in response to serpentine and non-serpentine substrates.

Methods - Field study - Five serpentine (S) and five non-serpentine (NS) sites were chosen for this study. The majority of the sites were located within Plumas National Forest with two sites in nearby Tahoe National Forest (Lat $39^{\circ} 33^{\prime} 45^{\prime \prime} \mathrm{N}$, Lon $\left.120^{\circ} 33^{\prime} 49^{\prime \prime} \mathrm{W}\right)$. Sites were located using a Trimble GeoXM containing shapefiles of USFS and CNDDB (California Natural Diversity Database, Department of Fish and Game, Sacramento, California) populations.

A stratified random sampling method was used to choose ten plants at each site. Plant functional trait measurements (Cornelissen et al., 2003) were taken at each plant and included diameter of basal rosette, height of tallest flower scape, number of leaves, number of flower scapes, number of reproductive units (fruits, flowers or buds), average 
flower size (diameter), average spike length, average leaf width, and specific leaf area. All measurements were taken to the nearest $0.01 \mathrm{~mm}$. Specific leaf area is the area of the leaf divided by its dry weight mass. Averages were derived by randomly selecting three flowers, spikes, or leaves to measure on a given plant and averaging the three.

Soil was collected from the rhizosphere of five different plants using a stainless steel hand trowel and totaling $200 \mathrm{~g}$ of soil per site. Soil analysis was done in the same manner as described in Chapter 1 (p. 10). Differences between substrates were analyzed using $t$-tests (Microsoft Excel 2007).

Ibutton temperature loggers (Maxim (C) were deployed at each site in a five $\mathrm{cm}$ piece of PVC pipe and attached with wire or string. They were left at the site from June 23-July 23, 2010. The loggers were set to take a temperature reading every two hours over the month.

Reciprocal transplant study - Approximately 2000 grams of rhizospheric field soil was collected from two serpentine and two non-serpentine sites and mixed together to make pooled serpentine and non-serpentine soil samples. In each treatment, 20 seeds from three serpentine sites (from 10 different mothers) and 20 seeds from three non-serpentine sites (from 10 different mothers) were sowed for germination ( $20 \times 3=60$ seeds representing three populations per soil treatment). This process was repeated for the non-serpentine soil. After being sown, all seeds were given a cold treatment in a growth chamber at $5^{\circ} \mathrm{C}$ for one month. 
Germinants were transplanted to five $\mathrm{cm}$ pots with the appropriate soil type. The first set was grown outside in San José and after discovering that they did not exhibit their normal growth form, the second set was grown in a growth chamber. The seedlings in the growth chamber were kept at a temperature of $10^{\circ} \mathrm{C}$ at night and $24^{\circ} \mathrm{C}$ during the day and the temperature was increased by a few degrees every couple of weeks until $15^{\circ} \mathrm{C}$ at night and $31^{\circ} \mathrm{C}$ during the day were reached. Trays containing seedlings were rotated in position in the growth chamber once every week, and both treatments were exposed to the same watering regime. Seedlings were measured every two weeks for diameter of entire plant, length of longest leaf, height and number of leaves. Percent purple leaf tissue in the plant was added as a measurement for the second (growth chamber) reciprocal transplant study. All measurements were taken in $\mathrm{mm}$ using digital calipers. Final growth measurements were compared in strains across and between substrates using two sample $t$-tests. Reaction norm graphs were also plotted to see if they showed evidence for local adaptation.

Results - Field study - Of all the functional traits measured in the field, diameter of basal rosette, number of leaves, height of plant, number of flower scapes, number of flowers, width, area and weight of dry leaves all differed significantly between substrates and were greater at non-serpentine sites (Table 18). The first principle component for the PCA on functional traits explained $44 \%$ of the variance and was mainly influenced by (in order from most to least important) weight of dry leaves, diameter, area, height, width, scape number, flower number, leaf number and spike size 
(Figure 11 and Table 19). The second principle component explained 14\% of the variance and was mainly influenced by (in order from most to least important) specific leaf area, flower size and leaf area (Figure 11 and Table 19).

Table 18. Functional traits.

\begin{tabular}{cccc}
\hline Variable & Serpentine & Non-serpentine & P-value \\
\hline Diameter & $101.36 \pm 3.59(60-170)$ & $137.86 \pm 5.89(46-260)$ & $<0.001$ \\
Leaf number & $35.16 \pm 1.17(18-59)$ & $40.7 \pm 1.36(24-66)$ & 0.001 \\
Height & $266.32 \pm 8.91(150-430)$ & $334.74 \pm 11.23(170-500)$ & $<0.001$ \\
Scape number & $2.08 \pm 0.14(1-4)$ & $2.98 \pm 0.18(1-6)$ & $<0.001$ \\
Flower number & $60.52 \pm 5.87(9-180)$ & $89.56 \pm 7.46(12-270)$ & 0.001 \\
Flower size & $9.54 \pm 0.25(5.6-13.5)$ & $10.15 \pm 0.309(5.6-15.3)$ & 0.06 \\
Spike size & $1.21 \pm 0.08(0.5-3)$ & $1.3 \pm 0.09(0.5-3)$ & 0.15 \\
Leaf width & $9.66 \pm 0.38(4.3-16.6)$ & $15.82 \pm 0.66(8-37)$ & $<0.001$ \\
Area & $469.7 \pm 23.6(226-857)$ & $1099.3 \pm 121.6(389-5321)$ & $<0.001$ \\
Weight & $66.4 \pm 5.7(18-180)$ & $131 \pm 8.3(46-263)$ & $<0.001$ \\
SLA & $8.19 \pm 0.35(4-14.1)$ & $8.17 \pm 0.44(3.5-22.6)$ & 0.48 \\
\hline
\end{tabular}

Notes: Results of functional traits analysis for five serpentine and five non-serpentine sites for $L$. cantelovii. Diameter, height, flower size, spike size, and leaf width are in $\mathrm{mm}$, area is in $\mathrm{mm}^{2}$ and weight is in $\mathrm{mg}$. Specific leaf area (SLA) is the ratio of fresh leaf area/dry leaf mass. Values listed are as follows: mean $\pm \mathrm{SE}$ (range), $\mathrm{n}=50$ (10 plants per five sites per substrate). P-values are based on a two sample t-test with significant values listed in bold font. 


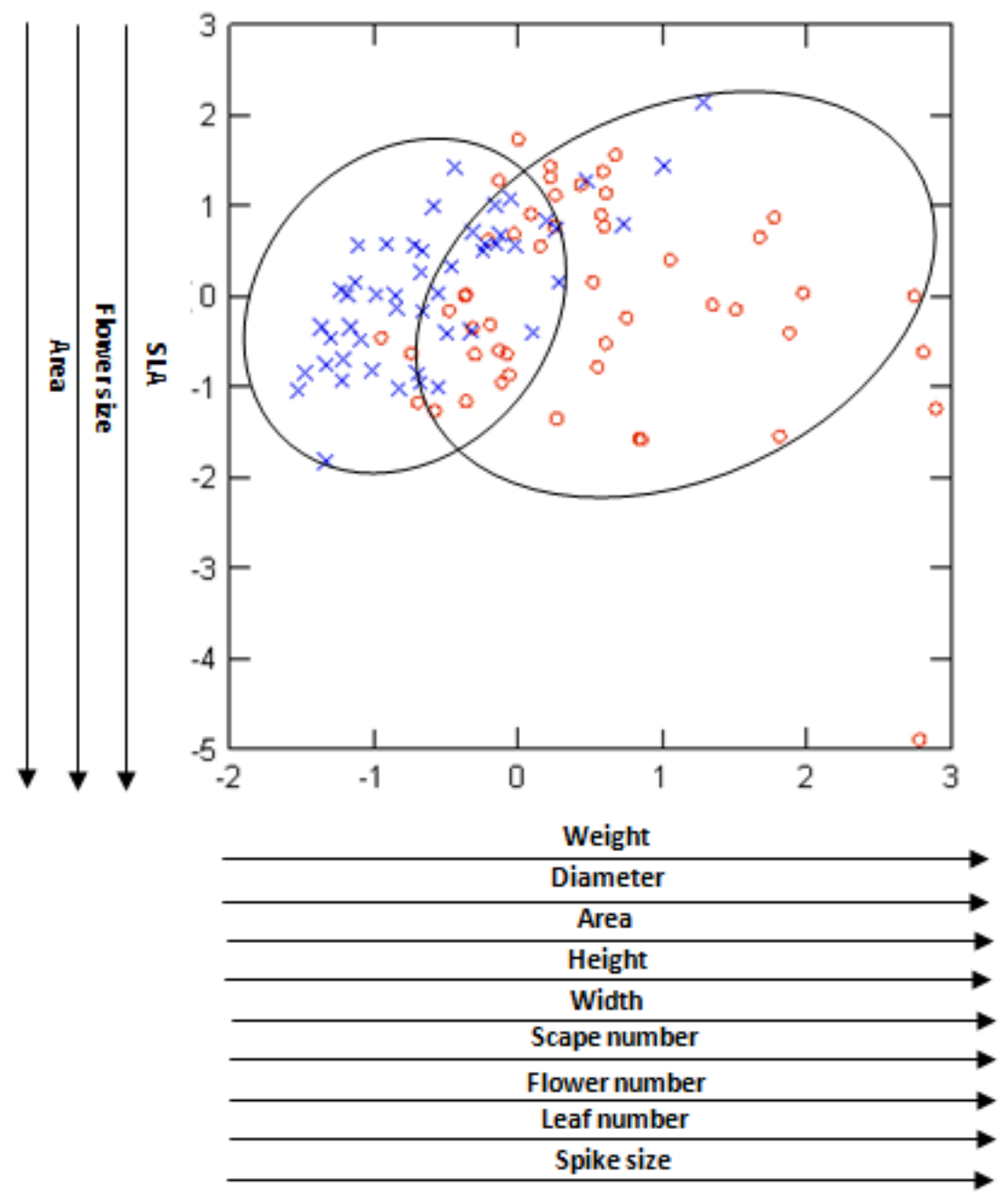

Figure 11. PCA for functional traits.

Notes: Shown in this PCA are the functional traits for serpentine and non-serpentine $L$. cantelovii populations ( $x$-axis is PC 1 and $y$-axis is PC 2). Arrows are in order of the loadings (the closest to the plot being the strongest loading) and their direction (negative or positive). Serpentine $=\mathrm{X} ;$ Non-serpentine $=0 ; \mathrm{n}=50$. 
Table 19. PCA for functional traits.

\begin{tabular}{|l|r|r|}
\hline & PC 1 & PC 2 \\
\hline Eigenvalues & \multicolumn{1}{|l|}{4.836} & \multicolumn{1}{l|}{1.526} \\
\hline \% variance explained & \multicolumn{1}{|l|}{43.967} & 13.873 \\
\hline & Loadings & \multicolumn{1}{l|}{ Loadings } \\
\hline Diameter & $\mathbf{0 . 8 4 3}$ & -0.270 \\
\hline Leaf number & $\mathbf{0 . 5 6 9}$ & 0.166 \\
\hline Height & $\mathbf{0 . 7 5 5}$ & 0.277 \\
\hline Scape number & $\mathbf{0 . 7 4 0}$ & 0.229 \\
\hline Flower number & $\mathbf{0 . 6 7 1}$ & 0.031 \\
\hline Flower size & -0.040 & $-\mathbf{0 . 5 6 3}$ \\
\hline Spike size & $\mathbf{0 . 5 1 4}$ & 0.253 \\
\hline Width & $\mathbf{0 . 7 4 5}$ & -0.027 \\
\hline Area & $\mathbf{0 . 8 0 3}$ & $-\mathbf{0 . 4 7 0}$ \\
\hline Weight & $\mathbf{0 . 8 7 5}$ & 0.020 \\
\hline SLA & 0.046 & $-\mathbf{0 . 8 3 2}$ \\
\hline
\end{tabular}

Notes: Principle components analysis for functional trait variables for five serpentine and five non-serpentine $L$. cantelovii sites. Eigenvalues, percent variance explained and component loadings are shown. Significant loadings are listed in bold.

Significant differences were found between substrates in $\mathrm{P}(\mathrm{S}<\mathrm{NS}), \mathrm{K}(\mathrm{S}<\mathrm{NS}), \mathrm{Mg}$ $(\mathrm{S}>\mathrm{NS}), \mathrm{S}(\mathrm{S}<\mathrm{NS})$, cation exchange capacity $(\mathrm{S}>\mathrm{NS})$, and $\mathrm{pH}(\mathrm{S}>\mathrm{NS})$ (Table 20). The first principle component for the PCA on soil variables explained $39 \%$ of the variance and was mainly influenced by (in order from most to least important) $\mathrm{pH}, \mathrm{Mg}$, cation exchange capacity, $\mathrm{P}, \mathrm{Fe}, \mathrm{Mn}, \mathrm{Cu}$, organic matter, $\mathrm{Ca}, \mathrm{Zn}, \mathrm{K}$ and $\mathrm{Ca} / \mathrm{Mg}$ ratio (Figure 12 and Table 21). The second principle component explained $30 \%$ of the variance and was 
mainly influenced by (in order from most to least important) $\mathrm{Na}, \mathrm{Ca} / \mathrm{Mg}$ ratio, $\mathrm{K}$, Moisture, Ni, Fe, Ca, Mn, organic matter, $\mathrm{Cu}, \mathrm{S}$ and $\mathrm{Mg}$ (Figure 12 and Table 21).

Table 20. Soil analysis for Lewisia cantelovii.

\begin{tabular}{cccc}
\hline $\begin{array}{c}\text { Soil } \\
\text { Variable }\end{array}$ & Serpentine & Non-serpentine & P-value \\
\hline $\mathrm{OM}$ & $3.58 \pm 0.51(2.5-4.9)$ & $14.52 \pm 5.27(3.9-34.4)$ & 0.05 \\
$\mathrm{P}$ & $5.64 \pm 1.43(2.6-10.3)$ & $14.66 \pm 2.78(4.4-21.3)$ & 0.01 \\
$\mathrm{pH}$ & $6.9 \pm 0.21(6.4-7.5)$ & $5.28 \pm 0.25(4.5-5.9)$ & $<0.001$ \\
$\mathrm{~K}$ & $42.26 \pm 4.78(29.6-54.8)$ & $73.56 \pm 13.47(43.7-114.9)$ & 0.04 \\
$\mathrm{Ca}$ & $732.34 \pm 339.39(220.8-2064)$ & $513.62 \pm 133.42(148.3-826.5)$ & 0.28 \\
$\mathrm{Mg}$ & $859.58 \pm 113.2(436.4-1023)$ & $93.44 \pm 15.89(51.2-130.5)$ & 0.001 \\
$\mathrm{Ca} / \mathrm{Mg}$ & $0.88 \pm 0.31(0.2-2)$ & $6.4 \pm 2.57(2.2-16.3)$ & 0.05 \\
$\mathrm{Na}$ & $15.66 \pm 1.25(12.2-19.2)$ & $18.48 \pm 2.92(11.5-27.7)$ & 0.2 \\
$\mathrm{CEC}$ & $11.16 \pm 2.13(5.8-18.8)$ & $5.16 \pm 0.61(3.3-6.3)$ & 0.02 \\
$\mathrm{~S}$ & $5.66 \pm 1.69(1.9-11.8)$ & $43.38 \pm 15.91(9.1-100.8)$ & 0.03 \\
$\mathrm{Ni}$ & $44.6 \pm 11.84(0.5-65.5)$ & $16.72 \pm 8.87(1-50.6)$ & 0.07 \\
$\mathrm{Zn}$ & $2.96 \pm 0.99(1.1-6)$ & $7 \pm 3.12(1.7-18.9)$ & 0.13 \\
$\mathrm{Mn}$ & $13.54 \pm 3(7.7-25)$ & $27.38 \pm 16.47(3.8-92)$ & 0.22 \\
$\mathrm{Fe}$ & $37.44 \pm 7.41(24.4-65)$ & $74.82 \pm 27.92(14.2-169)$ & 0.12 \\
$\mathrm{Cu}$ & $2.54 \pm 1.3(0.6-7.7)$ & $5.58 \pm 2.08(0.7-10.2)$ & 0.12 \\
$\mathrm{Moisture}$ & $1.74 \pm 0.35(0.01-4.1)$ & $0.66 \pm 0.26(0-3.1)$ & 0.01 \\
\hline
\end{tabular}

Notes: Soil analysis results for samples collected from five serpentine and five non-serpentine sites for L. cantelovii. Values displayed for organic matter (OM) are in percent, elemental concentrations are measured in $\mu \mathrm{g} \mathrm{g}^{-1} \mathrm{dry}$ soil (ppm), and cation exchange capacity (CEC) was measured in meq $100 \mathrm{~g}^{-1}$. Values listed are as follows: mean \pm SE (range), $\mathrm{n}=5$. P-values are based on a two sample t-test with significant values listed in bold font. 


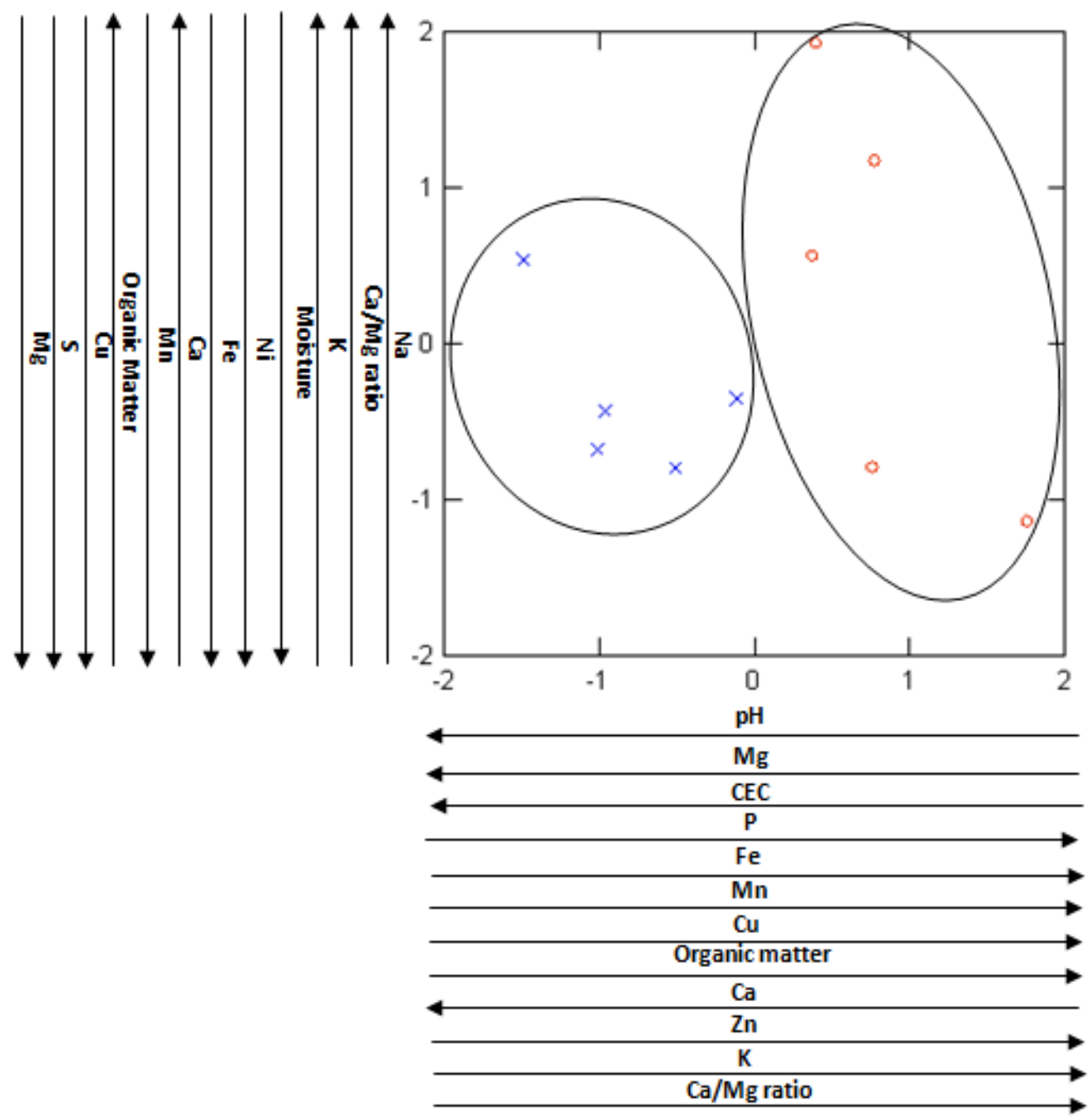

Figure 12. PCA of soil variables for Lewisia cantelovii.

Notes: Principle components analysis of soil variables for serpentine and non-serpentine L. cantelovii populations ( $\mathrm{x}$-axis is PC 1 and $\mathrm{y}$-axis is PC 2 ). Arrows are in order of the loadings (the closest to the plot being the strongest loading) and their direction (negative or positive). Serpentine $=\mathrm{X}$; Non-serpentine $=0 ; \mathrm{n}=5$. 
Table 21. PCA of soil variables for Lewisia cantelovii.

\begin{tabular}{|c|c|c|}
\hline & PC 1 & PC 2 \\
\hline Eigenvalues & 6.212 & 4.732 \\
\hline \multirow[t]{2}{*}{$\%$ variance explained } & 38.825 & 29.575 \\
\hline & Loadings & Loadings \\
\hline Organic matter & 0.536 & 0.415 \\
\hline$P$ & 0.773 & 0.130 \\
\hline $\mathrm{pH}$ & -0.987 & 0.013 \\
\hline K & 0.416 & 0.818 \\
\hline $\mathrm{Ca}$ & -0.522 & 0.512 \\
\hline $\mathrm{Mg}$ & -0.918 & -0.314 \\
\hline $\mathrm{Ca} / \mathrm{Mg}$ ratio & 0.338 & 0.827 \\
\hline $\mathrm{Na}$ & -0.022 & 0.957 \\
\hline Cation exchange capacity & -0.876 & 0.103 \\
\hline$S$ & 0.799 & -0.343 \\
\hline $\mathrm{Ni}$ & -0.286 & -0.670 \\
\hline $\mathrm{Zn}$ & 0.466 & 0.274 \\
\hline $\mathrm{Mn}$ & 0.615 & -0.489 \\
\hline $\mathrm{Fe}$ & 0.700 & -0.616 \\
\hline $\mathrm{Cu}$ & 0.605 & -0.364 \\
\hline Moisture & -0.095 & -0.714 \\
\hline
\end{tabular}

Notes: Principle components analysis for soil variables for five serpentine and five nonserpentine $L$. cantelovii sites. Eigenvalues, percent variance explained and component loadings are shown. Significant loadings are shown in bold font. 
Percent cover of boulders was significantly higher at non-serpentine sites and percent purple leaf tissue (per plant) was significantly higher at serpentine sites (Table 22). A native rust, Uromyces unitus Pk. (Pucciniaceae), was found in greater abundance on L. cantelovii at serpentine sites but was not found in significantly higher amounts (two sample t-test: $n=50, P>0.05$ ) (Table 22).

The dominant species found at serpentine sites were Pinus jeffreyi Grev. and Balf. (Jeffrey Pine; Pinaceae), Quercus durata Jeps. (Leather Oak; Fagaceae), Calocedrus decurrens (Torr.) Florin (Inscence Cedar; Cupressaceae), Avena sp. (Oat; Poaceae), and Epilobium minutum Lehm. (Willow Herb; Onagraceae). Non-dominants found at serpentine sites were Holodiscus microphyllus Rydb. (Rock Spiraea; Rosaceae), Aspidotis densa (Brack.) Lellinger (Indian's Dream; Pteridaceae), Gilia capitata Sims (Bluehead Gilia; Polemoniaceae), Sedum albomarginatum R. T. Clausen (Feather River Stonecrop; Crassulaceae) Penstemon deustus Lindl. (Scabland Penstemon; Plantaginaceae), Eriogonum ursinum S. Watson (Bear Valley Buckwheat; Polygonaceae), Umbellularia californica (Hook. and Arn.) Nutt. (California Bay; Lauraceae), Pseudotsuga menziesii (Mirb.) Franco (Douglas-Fir; Pinaceae), Streptanthus tortuosus Kellogg (Mountain Jewelflower; Brassicaceae) and various bryophytes. 
Table 22. Habitat variables for Lewisia cantelovii.

\begin{tabular}{cccc}
\hline Variable & Serpentine & Non-serpentine & P-value \\
\hline Aspect & $217.6 \pm 55.3(40-330)$ & $253.6 \pm 61.4(20-350)$ & 0.34 \\
Canopy Cover & $6.8 \pm 1.9(0-10)$ & $16.4 \pm 8.5(0-49)$ & 0.16 \\
Percent Rock & $70 \pm 9.3(45-90)$ & $51 \pm 14.1(15-85)$ & 0.15 \\
Percent Boulder & $69 \pm 6(50-80)$ & $96 \pm 2.4(90-100)$ & 0.004 \\
Percent Duff & $25 \pm 11.5(5-60)$ & $19.2 \pm 6.4(1-40)$ & 0.33 \\
Percent Shrub & $12.8 \pm 5.2(1-25)$ & $9 \pm 2.4(5-15)$ & 0.26 \\
Percent Herb & $41 \pm 14.2(15-95)$ & $66 \pm 10.6(40-85)$ & 0.1 \\
Percent Rust & $6.7 \pm 1.07(0-25)$ & $4.5 \pm 0.84(0-30)$ & 0.05 \\
Percent Purple & $20.34 \pm 3.1(0-80)$ & $3.18 \pm 1.2(0-60)$ & $<0.001$ \\
Percent LECA & $17 \pm 4.3(5-30)$ & $32 \pm 7.7(15-55)$ & 0.07 \\
\hline
\end{tabular}

Notes: Habitat variables for five serpentine and five non-serpentine sites for $L$. cantelovii. Values displayed for canopy cover are in percent and aspect is in degrees. Values listed are as follows: mean \pm SE (range). P-values are based on a two sample t-test with significant values are listed in bold. Sample size for percent rust and percent purple leaf tissue is $n=50$ and for all other variables $n=5$.

Moss and leafy liverworts were the dominant plants found at non-serpentine sites. In addition L. cantelovii, Heuchera micrantha Lindl. (Alum Root; Saxifragaceae), Pinus ponderosa Douglas ex Lawson and C. Lawson (Ponderosa Pine; Pinaceae) and Pseudotsuga menziesii were also dominants at some sites. Moss collections were made at one of the non-serpentine sites and identified by Dr. Jim Shevock (California Acadamy of Sciences). The species collected were Homalothecium pinnatifidum (Sull. and Lesq.) E. Lawton (Pinnatifid Homalothecium Moss; Brachytheciaceae), Polytrichum juniperinum Hedw. (Juniper Polytrichum Moss; Polytrichaceae), Grimmia leibergii Grev. (Grimmia Dry Rock Moss; Grimmiaceae), Dicranum howellii Renauld and Cardot (Howell's Dicranum Moss; Dicranaceae) and the leafy liverwort Scapania undulate (L.) Dumort. 
(Scapaniaceae). Other associated species found at non-serpentine sites were Quercus chrysolepis Liebm. (Oak; Fagaceae), Acer macrophyllum Pursh (Big-Leaf Maple;

Sapindaceae), Streptanthus tortuosus, Sedum spathulifolium Hook. (Broadleaf Stonecrop; Crassulaceae), Polystichum sp. and Ribes nevadense Kellogg (Mountain Pink Currant; Grossulariaceae).

On average (all times of day across the entire month) serpentine sites were $4^{\circ} \mathrm{C}$ hotter than non-serpentine sites (Figure 13). Since two Ibuttons were lost down steep ravines or stolen, this analysis only includes eight sites instead of ten.

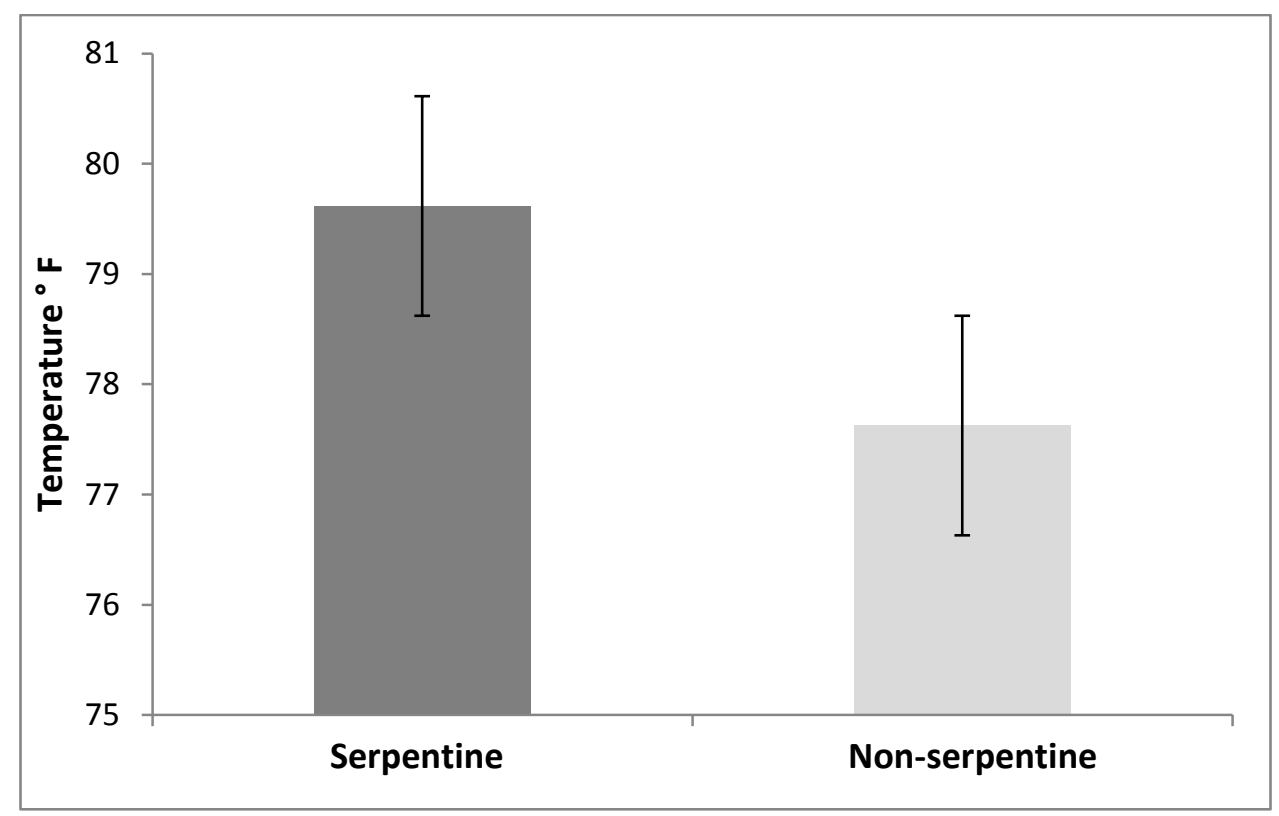

Figure 13. Temperature.

Notes: Average temperature from June23-July 23, 2010 for serpentine and non-serpentine $L$. cantelovii sites. Error bars indicate standard error. 
Reciprocal transplant study - For the first set of germination, in non-serpentine soil serpentine strains had a germination rate of $38 \%$ and non-serpentine strains had a germination rate of $28 \%$ (two sample t-test: $n=3, P=0.3$ ). In serpentine soil, serpentine strains had a germination rate of $62 \%$ and non-serpentine strains had a germination rate of $24 \%$ (two sample t-test: $n=3, P=0.06$ ). Survival rates for transplanted seedlings were $76 \%$ for serpentine strains in serpentine soil, $92 \%$ non-serpentine strains in serpentine soil, $95 \%$ serpentine strains in non-serpentine soil and $93 \%$ for non-serpentine strains in non-serpentine soil. Results from the final measurements of the first reciprocal transplant study can be seen in Table 23a with results of the $t$-tests shown in Table 23b.

For the second set of germination trials, serpentine strains had a germination rate of $26 \%$, in non-serpentine soil and non-serpentine strains had a germination rate of 41\% (two sample t-test: $n=6, P=0.07$ ). In serpentine soil, serpentine strains had a germination rate of $33 \%$ and non-serpentine strains had a germination rate of $45 \%$ (two sample t-test: $n=6, P=0.2$ ). Results from the final measurements of the second reciprocal transplant can be seen in Table 24a with results of the $t$-tests shown in Table 24b. The second reciprocal transplant showed local adaptation in regards to all measurements whereas the first reciprocal transplant only showed local adaptation in regards to width (Figures 14 and 15). 
Table 23a. Size Measurements - Lewisia cantelovii (1).

\begin{tabular}{ccccc}
\hline Variable & $\begin{array}{c}\text { Serp soil } \\
\text { Serp seeds }\end{array}$ & $\begin{array}{c}\text { Serp soil } \\
\text { Non-serp seeds }\end{array}$ & $\begin{array}{c}\text { Non-serp soil } \\
\text { Serp seeds }\end{array}$ & $\begin{array}{c}\text { Non-serp soil } \\
\text { Non-serp seeds }\end{array}$ \\
\hline $\mathrm{n}$ & 16 & 12 & 20 & 14 \\
Width & $17.4 \pm 2.1(7.2-34.5)$ & $15.9 \pm 1.7(8-27)$ & $12.2 \pm 1.2(3.6-22.3)$ & $16.4 \pm 1.3(9-23.2)$ \\
Height & $11.8 \pm 1.4(5-22)$ & $15.2 \pm 1.8(7-26)$ & $10.5 \pm 1.1(3-20)$ & $15.3 \pm 1.3(9-25)$ \\
Length & $7.8 \pm 0.9(3-14.2)$ & $10.5 \pm 1.2(5-18)$ & $6.4 \pm 0.6(2.1-10.9)$ & $8.5 \pm 0.7(4.8-12.6)$ \\
Leaf \# & $10.9 \pm 0.8(7-17)$ & $8.9 \pm 0.7(5-14)$ & $9.2 \pm 0.7(2-14)$ & $8.4 \pm 0.7(4-13)$ \\
\hline
\end{tabular}

Notes: Size measurement results for first $L$. cantelovii reciprocal transplant study (3/2/2010$3 / 3 / 2011$ ). All measurements are taken in $\mathrm{mm}$ and values reported are as follows: mean $\pm \mathrm{SE}$ (range). Variables measured include width of basal rosette, height of plant, length of longest leaf, and total number of leaves per plant.

Table 23b. Comparison of Size Measurements (1).

\begin{tabular}{|c|c|c|c|c|}
\hline Variable & $\begin{array}{c}\text { Serp soil } \\
\text { Serp seeds } \\
\text { vs } \\
\text { Serp soil } \\
\text { Non-serp seeds }\end{array}$ & $\begin{array}{l}\text { Non-serp soil } \\
\text { Serp seeds } \\
\text { vs } \\
\text { Non-serp soil } \\
\text { Non-serp seeds }\end{array}$ & $\begin{array}{l}\text { Serp soil } \\
\text { Serp seeds } \\
\text { vs } \\
\text { Non-serp soil } \\
\text { Serp seeds }\end{array}$ & $\begin{array}{c}\text { Serp soil } \\
\text { Non-serp seeds } \\
\text { vs } \\
\text { Non-serp soil } \\
\text { Non-serp seeds }\end{array}$ \\
\hline Width & $p=0.3$ & $p=0.01$ & $p=0.02$ & $p=0.4$ \\
\hline Height & $p=0.07$ & $p=0.01$ & $p=0.2$ & $p=0.5$ \\
\hline Length & $p=0.05$ & $p=0.01$ & $p=0.1$ & $p=0.09$ \\
\hline Leaf \# & $p=0.04$ & $p=0.2$ & $p=0.07$ & $p=0.3$ \\
\hline
\end{tabular}

Notes: P-values reported as a result of two sample $t$-tests run in order to compare $L$. cantelovii size measurements (see Table 23a) in serpentine and non-serpentine strains within the same substrate as well as serpentine and non-serpentine strains across substrates. Significant $p$-values are highlighted in bold. 
Table 24a. Size Measurements - Lewisia cantelovii (2).

\begin{tabular}{ccccc}
\hline Variable & $\begin{array}{c}\text { Serp soil } \\
\text { Serp seeds }\end{array}$ & $\begin{array}{c}\text { Serp soil } \\
\text { Non-serp seeds }\end{array}$ & $\begin{array}{c}\text { Non-serp soil } \\
\text { Serp seeds }\end{array}$ & $\begin{array}{c}\text { Non-serp soil } \\
\text { Non-serp seeds }\end{array}$ \\
\hline $\mathrm{N}$ & 20 & 26 & 15 & 24 \\
Width & $11.2 \pm 0.5(6.8-14.9)$ & $5.7 \pm 0.5(2-11)$ & $14.3 \pm 1.5(3.9-24.8)$ & $20.4 \pm 1.8(11.3-42.8)$ \\
Height & $7.0 \pm 0.5(5.0-14.1)$ & $6.1 \pm 0.3(5-9)$ & $8.8 \pm 0.6(6-14)$ & $14.8 \pm 1.9(4-36)$ \\
Length & $5.1 \pm 0.3(2.9-7.8)$ & $3.2 \pm 0.2(1.3-5.2)$ & $7.2 \pm 0.7(2.3-12.8)$ & $11.1 \pm 1.1(4.3-21.3)$ \\
Leaf \# & $10.8 \pm 0.7(6-18)$ & $4.3 \pm 0.3(2-7)$ & $8.6 \pm 0.8(2-14)$ & $12.7 \pm 1.0(7-22)$ \\
\% purple & $62.6 \pm 5.2(25-98)$ & $71.3 \pm 4.0(30-95)$ & $56.6 \pm 8.3(0-95)$ & $30 \pm 6.4(1-95)$ \\
\hline
\end{tabular}

Notes: Size measurement results for first $L$. cantelovii reciprocal transplant study (10/27/2010$3 / 22 / 2011$ ). All measurements are taken in $\mathrm{mm}$ and values reported are as follows: mean $\pm \mathrm{SE}$ (range). Variables measured include width of basal rosette, height of plant, length of longest leaf, total number of leaves per plant, and percent of purple leaf tissue per plant.

Table 24b. Comparison of Size Measurements (2).

\begin{tabular}{|c|c|c|c|c|}
\hline Variable & $\begin{array}{c}\text { Serp soil } \\
\text { Serp seeds } \\
\text { vs. } \\
\text { Serp soil } \\
\text { Non-serp seeds }\end{array}$ & $\begin{array}{l}\text { Non-serp soil } \\
\text { Serp seeds } \\
\text { vs. } \\
\text { Non-serp soil } \\
\text { Non-serp seeds }\end{array}$ & $\begin{array}{c}\text { Serp soil } \\
\text { Serp seeds } \\
\text { vs. } \\
\text { Non-serp soil } \\
\text { Serp seeds }\end{array}$ & $\begin{array}{c}\text { Serp soil } \\
\text { Non-serp seeds } \\
\text { vs. } \\
\text { Non-serp soil } \\
\text { Non-serp seeds }\end{array}$ \\
\hline Width & $p=0$ & $p=0.007$ & $p=0.03$ & $p=0$ \\
\hline Height & $p=0.07$ & $p=0.003$ & $p=0.01$ & $p=0$ \\
\hline Length & $p=0$ & $p=0.003$ & $p=0.007$ & $p=0$ \\
\hline Leaf \# & $p=0$ & $p=0.001$ & $p=0.02$ & $p=0$ \\
\hline$\%$ purple & $p=0.09$ & $p=0.008$ & $p=0.27$ & $p=0$ \\
\hline
\end{tabular}

Notes: P-values reported as a result of two sample $t$-tests run in order to compare $L$. cantelovii size measurements (see Table 24a) in serpentine and non-serpentine strains within the same substrate as well as serpentine and non-serpentine strains across substrates. Significant $p$-values are highlighted in bold. 

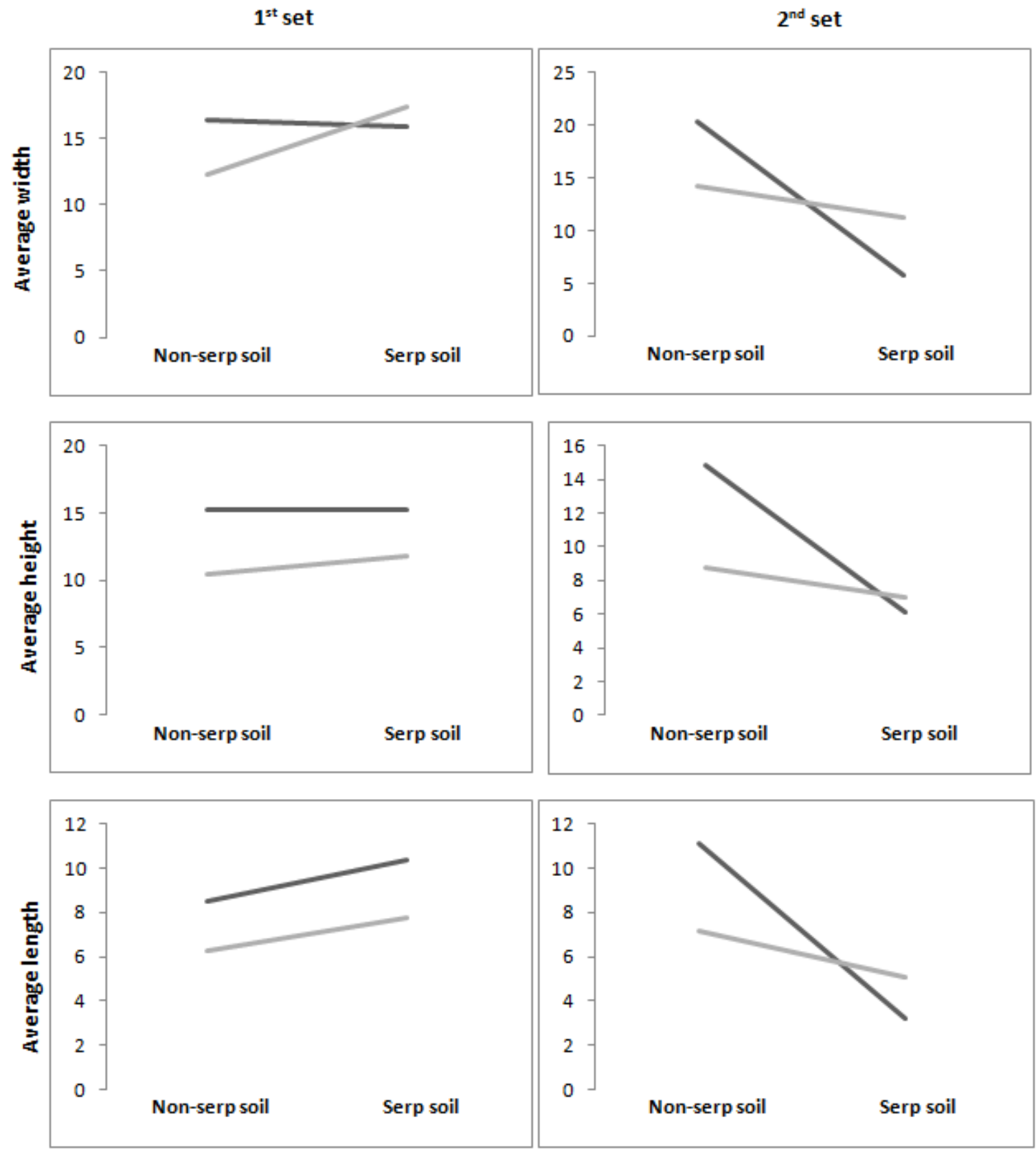

Figure 14. Reaction Norms (1)

Notes: Average width, height and length for both sets of $L$. cantelovii reciprocal transplants. Averages are from the final set of measurements. Experiments ran from 3/2/2010-3/3/2011 for the first set and 10/27/2010-3/22/2011 for the second set. 

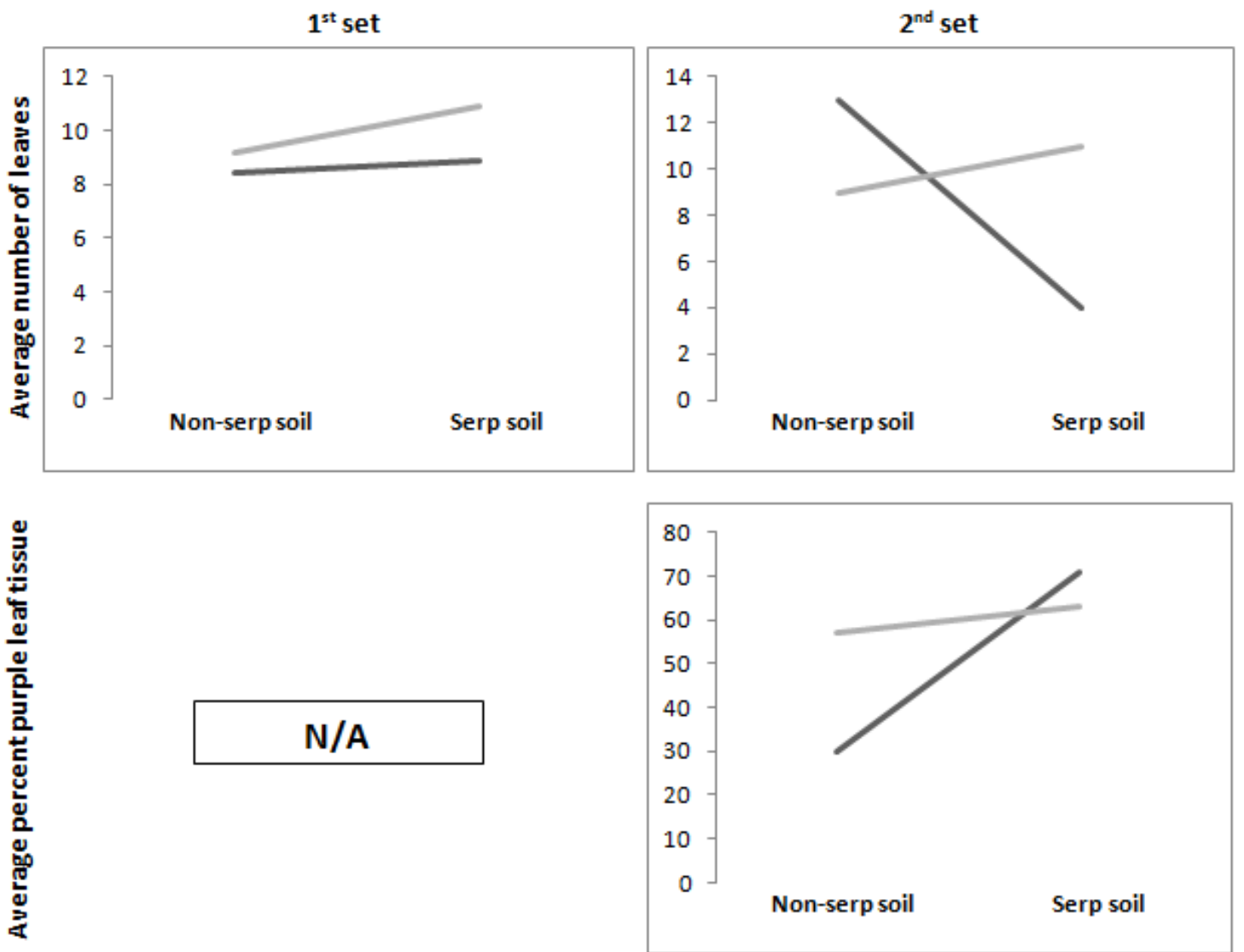

Figure 15. Reaction Norms (2)

Notes: Average number of leaves and percent purple leaf tissue for both sets of $L$. cantelovii reciprocal transplants. Percent purple leaf tissue was not measured in the first reciprocal transplant experiment. Averages are from the final set of measurements. Experiments ran from $3 / 2 / 2010-3 / 3 / 2011$ for the first set and $10 / 27 / 2010-3 / 22 / 2011$ for the second set.

$=$ non-serpentine strain $=$ serpentine strain 
Discussion - Field Study - Consistent with other studies that have looked at serpentine and non-serpentine populations of the same species (Kruckeberg, 1951; Kruckeberg, 1984; O'Dell and Rajakaruna, 2011), the L. cantelovii plants found growing on non-serpentine soils were significantly larger than those growing on serpentine soils. These edaphically distinct populations showed clear separation in PCA space in regards to functional traits of the plants and ion content of the soil. Above-ground habitat variables were not significantly different between serpentine and non-serpentine sites. This species therefore has specific above-ground habitat requirements yet is able to adapt to a range of edaphic conditions.

When looking at speciation from an ecological context, local adaptation can play a key role (Givnish, 2010). While some plants may be able to exhibit phenotypic plasticity (Bradshaw, 1965; Valadares et al., 2007) and are found on a wide range of habitats and edaphic conditions, some adapt to these new conditions and this variation can spawn speciation events (Givnish, 2010). Serpentine endemics have been known to evolve from more common plants growing on normal soils (Baldwin, 2005) and morphological differences such as flower color have been witnessed between serpentine and non-serpentine populations that could lead to speciation events (Kay et al., 2011). Further studies are needed to look for genetic differences in edaphically and morphologically distinct populations of Lewisia cantelovii.

Reciprocal transplant study - In the reciprocal transplant study, non-serpentine strains are showing early evidence for local adaptation to non-serpentine soil. This early 
evidence can be seen in the width of the leaves, height of the plant, length and number of leaves. Overall, when strains from normal soil were transplanted into serpentine soil, their level of fitness decreases. In order to say conclusively if local adaptation is occurring, I need a measure of reproductive fitness. After the seedlings have been allowed to grow for a few more years, I hope to get reproductive data to look for differences between these populations. It is possible that with more time, this slow growing perennial may show evidence for local adaptation to serpentine soil as well. 


\section{CHAPTER FOUR}

Discussion - In an ideal world, ample funding and priority would be given to the study and observation of rare and common species alike. Unfortunately, this is simply not the case. There are over 7000 plant species in California, and with over 2000 ( 30\%) of them found nowhere else on Earth (Safford et al., 2005), California is a biodiversity hotspot (Myers et al., 2000). Being that rare plants contribute a great deal to Earth's biodiversity and are by their nature at a higher risk of extinction than common plants, it is critical to study them to be informed for best management practices.

Having an understanding of genetic diversity is critically important for the conservation of rare plants (Ellstrand and Elam, 1993). While a monograph on the genus Monardella (Epling, 1925), as well as a recent paper looking at nomenclature changes (Elvin and Sanders, 2009) have been published, there is no published literature on genetics within this genus, and very little work has been done on other aspects of the biology and ecology of the taxa. Based on morphological characteristics, M. follettii and M. stebbinsii are not believed to be closely related (Elvin and Sanders, 2009), but their genetic relationship may tell a different story. It is not known how diverse the populations of these Monardella's are; however, current research in Dr. Kathleen Kay's Lab (University of California, Santa Cruz) will better inform us about the genetic structure within each species as well as the relationships between the two. 
Since there are three other common Monardellas that grow in the area ( $M$. sheltonii, M. odoratissima, M. lanceolata), hybridization is frequent throughout this genus (Baldwin et al., 2012), and hybrids between M. follettii and M. sheltonii are commonly observed, it is important to have an understanding of how many known populations are pure species. In order to understand the nature and direction of evolution for these two taxa as well as their relatedness, it is critical to have a phylogeny done for the genus.

Since edaphically distinct populations of $L$. cantelovii have proven to be morphologically distinct and are showing evidence for local adaptation, there could be important implications for conservation of this already rare taxon if edaphically distinct populations also proved to be genetically unique. Future studies on L. cantelovii should include a genetic component to investigate any genetic differentiation between edaphically distinct populations.

Rare plants are more likely to be found in "unique" habitats than in "normal" habitats (Kruckeberg and Rabinowitz, 1985) and serpentine outcrops are a unique habitat for plants found throughout the world (Brooks, 1987; Roberts and Proctor, 1992). Due to the patchy distribution of many rare serpentine endemic plants, there is a need for more small preserves and other means of conservation than is necessary for rare plants growing on normal soils (Thorne et al., 2011). Considering the difficulty in prioritizing conservation for plant species as a whole (Schemske et al., 1994), this matter is complicated even further for serpentine endemics (Thorne et al., 2011). 
It is ideal to choose large serpentine patches vs. small, and those that contain more endemic species vs. less for conservation priorities (Harrison, 1999). In a study by Harrison et al. (2008), the authors used a database of rare species within California's serpentine flora to test the favorable-environment hypothesis. Their findings showed that favorable environments support higher numbers of rare and endemic species and that these species are more likely to be found in areas where the specialized habitat is extensive. The belt of ultramafics known as the Feather River Complex is one of the largest and most continuous areas of serpentine in the Sierra Nevada (Alexander et al., 2007). It is found in the Northern-most portion of the Sierra range, and has higher amounts of rainfall than the rest of the range, thereby providing a more favorable environment. This area is therefore a high priority for conservation as it hosts many rare and endemic species, provides a large area of serpentine, is a relatively favorable environment, and does not experience great development or land conversion pressures (Thorne et al., 2011).

In conserving rare plant species, focusing on groups of species that could benefit from similar conservation actions is the most efficient way to get the most out of conservation efforts (Vellak et al., 2008). Systematic conservation planning based on prioritizing areas that have high biodiversity is a must (Thorne et al., 2011). Approximately 80 plants out of 2000 in Plumas National Forest are rare and about 35 of these are serpentine endemics (Hanson, 1999; Clifton, 2005). The Feather River Basin and Plumas County contain 95 and 66 rare taxa, respectively (Shevock, 1996). Plumas 
National Forest is in the Northern most portion of the Sierra Nevada just South of the Cascade Range. Shevock (1996), points out that the reason for the large number of rare taxa in this area is due to its close proximity to the Cascade Range. While still supporting rare and endemic species from the Sierra Nevada, many rare species from the Cascades and the Klamath Mountains are found in their most southerly populations in the Feather River Basin (Shevock, 1996). Species populations on the edge of their geographic range are often characterized by a reduction in genetic diversity (Freeland et al., 2010). This factor along with the large amount of biodiversity found in Plumas National Forest, make it a high priority and of important conservation value (Thorne et al., 2011).

Human-caused rapid climate change will be altering ecosystems throughout the world for years to come (Loarie et al., 2009; Damschen et al., 2011). We may be presented with situations in the near future where preemptive restoration or managed relocation will be necessary for rare plants since they do not have the ability to get up and move (Richardson et al., 2009). While climate models cannot inform us of the exact direction species will need to move (Ackerly et al., 2010), we know that the case for serpentine plants and those found on other harsh or unique substrates will be different (Loarie et al., 2008). Plant species that are endemic to serpentine face challenges similar to species found on mountaintop areas or islands (Benito et al., 2011). If changes in climate force them to move north or south over great distances, they are 
faced with vast areas of unsuitable habitat that they will need to cross in order to get there (Damschen et al., 2011).

Land managers are charged with the task of managing for rare species yet in order to do so it is critical to have a basic understanding of the biology and ecology of these little known species. Considering the large amount of rare species that exist throughout the world (not to mention those that may still be unknown to science), knowledge of these species is scarce. While shifting the focus of conservation plans from a single species approach to that which protects biodiversity and ecosystem services in general is critical, the more knowledge we can gain on individual species the more pieces of the puzzle we have to put together as we work towards conserving our precious resources and biodiversity worldwide. 


\section{LITERATURE CITED}

Ackerly, D. D., S. R. Loarie, W. K. Cornwell, S. B. Weiss, H. Hamilton, R. Branciforte, and N. J. B. Kraft. 2010. The geography of climate change: Implications for conservation biogeography. Diversity and Distributions 16: 476-487.

Alexander, E. B., R. G. Coleman, T. Keeler-Wolf, and S. Harrison. 2007. Serpentine Geoecology of Western North America. Oxford University Press, New York, NY, USA.

Alexander, E. B. 2009. Soil and vegetation differences from peridotite to serpentinite. Northeastern Naturalist 16: 178-192.

Anacker, B. L., J. B. Whittal, E. E. Goldberg, and S. P. Harrison. 2010. Origins and consequences of serpentine endemism in the California flora. Evolution 65: 365376.

Baker, A. J. M. 1981. Accumulators and excluders - strategies in the response of plants to heavy metals. Journal of Plant Nutrition 3: 643-654.

Baldwin, B. G. 2005. Origin of the serpentine-endemic herb Layia discoidea from the widespread L. glandulosa (Compositae). Evolution 59: 2473-2479.

Baldwin, B. G., D. H. Goldman, D. J. Keil, R. Patterson, T. J. Rosatti, and D. H. Wilken (eds). 2012. The Jepson Manual: Vascular Plants of California, $2^{\text {nd }}$ ed. University of California Press, Berkeley and Los Angeles, California, USA.

Batianoff, G. N. and S. Singh. 2001. Central Queensland serpentine landforms, plant ecology, and endemism. South African Journal of Science 97: 495-500.

Benito, B., J. Lorite, and J. Peñas. 2011. Simulating potential effects of climatic warming on altitudinal patterns of key species in Mediterranean-alpine ecosystems.

Climate Change 108: 471-483.

Bevill, R. L. and S. M. Louda. 1999. Comparisons of related rare and common species in the study of plant rarity. Conservation Biology 13: 493-498.

Bernhardt, P. and R. Edens-Meier. 2010. What we think we know vs. what we need to know about orchid pollination and conservation: Cypripedium L. as a model lineage. The Botanical Review 76: 204-219 
Bomblies, K. 2010. Doomed lovers: Mechanisms of isolation and incompatibility in plants. Annual Review of Plant Biology 61: 109-124.

Boyd, R. S., A. R. Kruckeberg and N. Rajakaruna. 2009. Biology of ultramafic rocks and soils: Research goals for the future. Northeastern Naturalist 16: 422-440.

Bradshaw, A. D. 1965. Evolutionary significance of phenotypic plasticity in plants. Advances in genetics 13: 115-155.

Brady, K. U., A. R. Kruckeberg and H. D. Bradshaw Jr. 2005. Evolutionary ecology of plant adaptation to serpentine soils. Annual Review of Ecology, Evolution and Systematics 36: 243-266.

Brooks, R. R. 1987. Serpentine and its Vegetation: A Multidisciplinary Approach. Dioscorides Press, Portland, OR, USA.

Brumback, W. E. 1989. Notes on propagation of rare New England species. Rhodora 91: $154-162$.

Carlsen, T. M., E. K. Espeland and B. M. Pavlik. 2002. Reproductive ecology and the persistence of an endangered plant. Biodiversity and Conservation 11: 12471268.

California Native Plant Society (CNPS). 2010. Inventory of Rare and Endangered Plants (online edition, v7-10d). California Native Plant Society, Sacramento, CA. Website http://www.cnps.org/inventory [accessed on 07 Nov 2010]

California Natural Diversity Database. 2010. RareFind Version 4. California Department of Fish and Game, Sacramento, CA, USA.

Clifton, G. 2005. Plumas County and Plumas National Forest Flora. Prepared for the USDA Forest Pacific Southwest Region, Vallejo, CA, USA.

Coppoletta, M. and S. Woolhouse. 2010. Conservation assessment for Monardella stebbinsii Hardham and Bartel (Stebbin's wild mint). Prepared for the USDA Forest Service Pacific Southwest Region, Vallejo, CA, USA.

Cornelissen, J. H. C., S. Lavorel, E. Garnier, S. Díaz, N. Buchmann, D. E. Gurvich, P. B. Reich, H. ter Steege, H. D. Morgan, M. G. A. van der Heijden, J. G. Pausas and H. Poorter. 2003. A handbook of protocols for standardized and easy 
measurement of plant functional traits worldwide. Australian Journal of Botany 51: $335-380$.

Damschen, E. L., S. Harrison, B. M. Going, and B. L. Anacker. 2011. Climate change and plant communities on unusual soils. In S. P. Harrison and N. Rajakaruna [eds.], Serpentine: The Evolution and Ecology of a Model System, 359-381. University of California Press, Berkeley, CA, USA

Drury, W. H. 1980. Rare species of plants. Rhodora 82: 3-48.

Ellis, A. G., A. E. Weis, and B. S. Gaut. 2006. Evolutionary radiation of "stone plants" in the genus Argyroderma (Aizoaceae): Unraveling the effects of landscape, habitat, and flowering time. Evolution 60: 39-55.

Ellis, A. G. and A. E. Weis. 2006. Coexistence and differentiation of 'flowering stones': the role of local adaptation to soil microenvironment. Journal of Ecology 94: 322-335.

Ellstrand N. C. and D. R. Elam. 1993. Population genetic consequences of small population size: Implications for plant conservation. Annual Review of Ecology and Systematics 24: 217-242.

Elvin, M. A. and A. C. Sanders. 2009. Nomenclatural changes for Monardella (Lamiaceae) in California. Novon 19: 315-343.

Epling, C. C. 1925. Monograph of the genus Monardella. Annals of the Missouri Botanical Garden 12: 1-106.

Espeland, E. K. and T. M. Emam. 2011. The value of structuring rarity: The seven types and links to reproductive ecology. Biodiversity and Conservation 20: 963-985.

Freeland, J. R., J. Gillespie, C. Ciotir, and M. E. Dorken. 2010. Conservation genetics of Hill's thistle (Cirsium hillii). Botany 88: 1073-1080.

Gavlak, R., D. Horneck, R. O. Miller, and J. Kotuby-Amacher. 2003. Soil, plant and water reference methods for the Western region, $2^{\text {nd }}$ ed. WCC-103 Publication, WREP125 Wetland Reserve Enhancement Program, U.S. Department of Agriculture, Corvallis, OR, USA.

Givnish, T. J. 2010. Ecology of plant speciation. Taxon 59: 1326-1366.

Gurevitch, J., S. M. Scheiner and G. A. Fox. 2002. The Ecology of Plants. Sinauer 
Associates, Inc., Sunderland, MA, USA.

Hanson, L. 1999. Plumas National Forest rare plant handbook. Prepared for the USDA Forest Service Pacific Southwest Region, Vallejo, CA, USA.

Harper, K. T. 1979. Some reproductive and life history characteristics of rare plants and implications of management. In The Endangered Species: A symposium, 129137. Brigham Young University, Provo, UT, USA.

Harrison, S. 1999. Native and alien species diversity at the local and regional scales in a grazed Californian grassland. Oecologia 121: 99-106.

Harrison, S. and B. D. Inouye. 2002. High beta diversity in the flora of California serpentine "islands." Biodiversity and Conservation 11: 1869-1876.

Harrison, S., J. H. Viers, J. H. Thorne and J. B. Grace. 2008. Favorable environments and the persistence of naturally rare species. Conservation Letters 1: 65-74.

Karlsson, L. M. and P. Milberg. 2008. Variation within species and inter-species comparison of seed dormancy and germination of four annual Lamium species. Flora 203: 409-420.

Kay, K. M., K. L. Ward, L. R. Watt and D. W. Schemske. 2011. Plant Speciation. In S. P. Harrison and N. Rajakaruna [eds.], Serpentine: The Evolution and Ecology of a Model System, 71-95. University of California Press, Berkeley, CA, USA.

Kazakou, E., P. G. Dimitrakopoulos, A. J. M. Baker, R. D. Reeves and A. Y. Troumbis. 2008. Hypotheses, mechanisms and trade-offs of tolerance and adaptation to serpentine soils: From species to ecosystem level. Biological Review 83: 495508.

Kearns, C. A. and D. W. Inouye. 1997. Pollinators, flowering plants, and conservation biology: Much remains to be learned about pollinators and plants. Bioscience 47: 297-307.

Kearns, C. A., D. W. Inouye and N. M. Waser. 1998. Endangered mutualisms: The conservation of plant-pollinator interactions. Annual Review of Ecology and Systematics 29: 83-112.

Klack, C., G. Reeves, and T. Hedderson. 2004. Unmatched tempo of evolution in Southern African semi-desert ice plants. Nature 427: 63-65. 
Kruckeberg, A. R. 1951. Intraspecific variability in the response of certain native plant species to serpentine soil. American Journal of Botany 38: 408-419.

Kruckeberg, A. R. 1984. California Serpentines: Flora, Vegetation, Soils, and Management Problems. University of California Press, Berkeley, CA, USA.

Kruckeberg, A. R. and D. Rabinowitz. 1985. Biological aspects of endemism in higher plants. Annual Review of Ecology and Systematics 16: 447-479.

Kunin, W. E. and K. J. Gaston. 1993. The biology of rarity: Patterns, causes and consequences. Trends in Evolution and Ecology 8: 298-301.

Lindsay, W. L. and W. A. Norvell. 1978. Development of a DTPA soil test for zinc, iron, manganese, and copper. Journal of Soil Science 42: 421-428.

Lipow, S. R., P. Bernhardt, and N. Vance. 2005. Comparative rates of pollination and fruit set in widely separated populations of a rare orchid (Cypripedium fasciculatum). International Journal of Plant Sciences 163: 775-782.

Loarie, S. R., B. E. Carter, K. Hayhoe, S. McMahon, R. Moe, C. A. Knight, and D. D. Ackerly. 2008. Climate change and the future of California's endemic flora. Plos One 3: 1-10.

Mills, M. H. and M. W. Schwartz. 2005. Rare plants at the extremes of distribution: Broadly and narrowly distributed rare species. Biodiversity and Conservation 14: 1401-1420.

Myers, N., R. A. Mittermeler, C. G. Mittermeier, G. A. B. da Fonseca and J. Kent. 2000. Broadly and narrowly distributed rare species. Biodiversity and Conservation 14: 1401-1420.

O'Dell, R. E. and V. P. Classen. 2011. Restoration and Revegetation of Harsh Soils. In S. P. Harrison and N. Rajakaruna [eds.], Serpentine: The Evolution and Ecology of a Model System, 383-413. University of California Press, Berkeley, CA, USA.

O'Dell, R. E. and N. Rajakaruna. 2011. Intraspecific Variation, Adaptation, and Evolution. In S. P. Harrison and N. Rajakaruna [eds.], Serpentine: The Evolution and Ecology of a Model System, 97-137. University of California Press, Berkeley, CA, USA.

Rajakaruna, N. and B. A. Bohm. 1999. The edaphic factor and patterns of variation in 
Lasthenia californica (Asteraceae). American Journal of Botany 86: 1576-1596. Rajakaruna, N. 2004. The edaphic factor in the origin of plant species. International Geology Review 46: 471-478.

Ramp Neale, J. M., T. A. Ranker, and S. K. Collinge. 2008. Conservation of rare species with island-like distributions: A case study of Lasthenia conjugens (Asteraceae) using population genetic structure and the distribution of rare markers. Plant Species Biology 23: 97-110.

Raven, P. H. and D. I. Axelrod. 1978. Origin and Relationships of the California Flora. University of California Publications in Botany, Vol. 72. University of California Press, Berkeley, CA, USA.

Richardson, D. M., J. J. Hellmann, J. S. McLachlan, D. F. Sax, M. W. Schwartz, P. Gonzalez, E. J. Brennan, A. Camacho, T. L. Root, O. E. Sala, S. H. Schneider, D. M. Ashe, J. R. Clark, R. Early, J. R. Etterson, E. D. Fielder, J. L. Gill, B. A. Minteer, S. Polasky, H. D. Safford, A. R. Thompson, and M. Vellend. 2009. Multidimensional evaluation of managed relocation. Proceedings of the National Academy of Sciences 106: 9721-9724.

Richerson, S. J. C. 1997. Interim management guide for Lewisia cantelovii J.T. Howell and Lewisia serrata Heckard and Stebbins. Prepared for the USDA Forest Service Pacific Southwest Region, Vallejo, CA, USA.

Roberts, B. A. and J. Proctor [eds.], 1992. The Ecology of Areas with Serpentinized Rocks: A World View. Kluwer Academic Publishers, Dordrecht, The Netherlands.

Sadler, K. D. and G. E. Bradfield. 2010. Ecological facets of plant species rarity in rock outcrop ecosystems of the Gulf Islands, British Columbia. Botany 88: 429-434.

Safford, H. D., J. H. Viers and S. P. Harrison. 2005. Serpentine endemism in the California flora: A database of serpentine affinity. Madroño 52: 222-257.

Sargent, R. D. and D. D. Ackerly. 2008. Plant-pollinator interactions and the assembly of plant communities. Trends in Ecology and Evolution 23: 123-130.

Schemske, D. W., B. C. Husband, M. H. Ruckelshaus, C. Goodwillie, I. M. Parker, and J. G. Bishop. 1994. Evaluating approaches to the conservation of rare and endangered plants. Ecology 75: 584-606.

Shefferson, R. P., M. Weiss, T. Kull, and D. L. Taylors. 2005. High specificity generally 
characterizes mycorrhizal association in rare lady's slipper orchids, genus Cypripedium. Molecular Ecology 14: 613-626.

Shevock, J. R. 1996. Status of Rare and Endemic Plants. Report for the Sierra Nevada Ecosystem Project: Final report to Congress, vol. II. University of California, Centers for Water and Wildland Resources, Davis, CA, USA.

Sprague, E. F. 1962. Pollination and evolution in Pedicularis (Scrophulariaceae). Aliso 5: 181-209.

Stebbins, G. L. 1942. The genetic approach to problems of rare and endemic species. Madroño 6: 241-272.

Stebbins, G. L. 1980. Rarity of plant species: A synthetic viewpoint. Rhodora 82: 7785.

Thorne, J. H., P. R. Huber, and S. P. Harrison. 2011. Systematic Conservation Planning. In S. P. Harrison and N. Rajakaruna [eds.], Serpentine: The Evolution and Ecology of a Model System, 309-328. University of California Press, Berkeley, CA, USA.

Tuomisto, H. 2006. Edaphic niche differentiation among Polybotra ferns in western Amazonia: Implications for coexistence and speciation. Ecography 29: 273-284.

Valladares, F., E. Gianoli, and J. M. Gómez. 2007. Ecological limits to plant phenotypic plasticity. New Phytologist 176: 749-763.

United States Department of Agriculture and Natural Resources Conservation Services (USDA/NRCS). 2011. The PLANTS Database [online]. National Plant Data Team, Greensboro, NC, USA. Website http://plants.usda.gov [accessed 4 December 2011].

Vellak, A., E. L. Tuvi, U. Reier, R. Kalamees, E. Roosaluste, M. Zobel, and M. Pärtel. 2008. Past and present effectiveness of protected areas for conservation of naturally and anthropogenically rare plant species. Conservation Biology 23: 750-757.

Waser, N. M. and J. Ollerton. 2006. Plant-pollinator interactions: From specialization to generalization. The University of Chicago Press, Chicago, IL, USA.

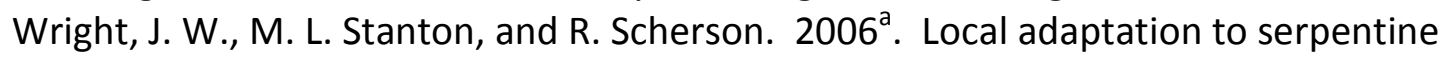
and non-serpentine soils in Collinsia sparsiflora. Evolutionary Ecology Research 8: $1-21$. 
Wright, J. W., K. F. Davies, J. A. Lau, A. C. McCall, and J. K. McKay. 2006 ${ }^{\mathrm{b}}$. Experimental verification of ecological niche modeling in a heterogeneous environment.

Ecology 87: 2433-2439.

Wright, J. W. and M. L. Stanton. 2007. Collinsia sparsiflora in serpentine and nonserpentine habiats: Using F2 hybrids to detect the potential role of selection in ecotypic differentiation. New Phytologist 173: 354-366.

Wright, J. W. 2007. Local adaptation to serpentine soils in Pinus ponderosa. Plant and Soil 293: 209-217.

Wright, J. W. and Stanton, M. L. 2011. Local Adaptation in Heterogeneous Landscapes: Reciprocal Transplant Experiments and Beyond. In S. P. Harrison and N. Rajakaruna [eds.], Serpentine: The Evolution and Ecology of a Model System, 155-179. University of California Press, Berkeley, CA, USA.

Yost, J. M., T. Barry, K. M. Kay, and N. Rajakaruna. 2012. Edaphic adaptation maintains the coexistence of two cryptic species on serpentine soil. American Journal of Botany 99: 890-897. 